\title{
Avaliação Clínica de Restaurações de Lesões Cervicais não Cariosas
}

\section{SÉRGIO LIMA SANTIAGO}

Tese apresentada à Faculdade de Odontologia de Bauru, da Universidade de São Paulo, como parte dos requisitos para obtenção do título de Doutor em Odontologia, área de Dentística.

(Edição Revisada)

BAURU 


\section{Avaliação Clínica de Restaurações de Lesões Cervicais não Cariosas}

\section{SÉRGIO LIMA SANTIAGO}

Tese apresentada à Faculdade de Odontologia de Bauru, da Universidade de São Paulo, como parte dos requisitos para obtenção do título de Doutor em Odontologia, área de Dentística.

(Edição Revisada)

Orientador: Prof. Dr. Eduardo Batista Franco

BAURU

2002 


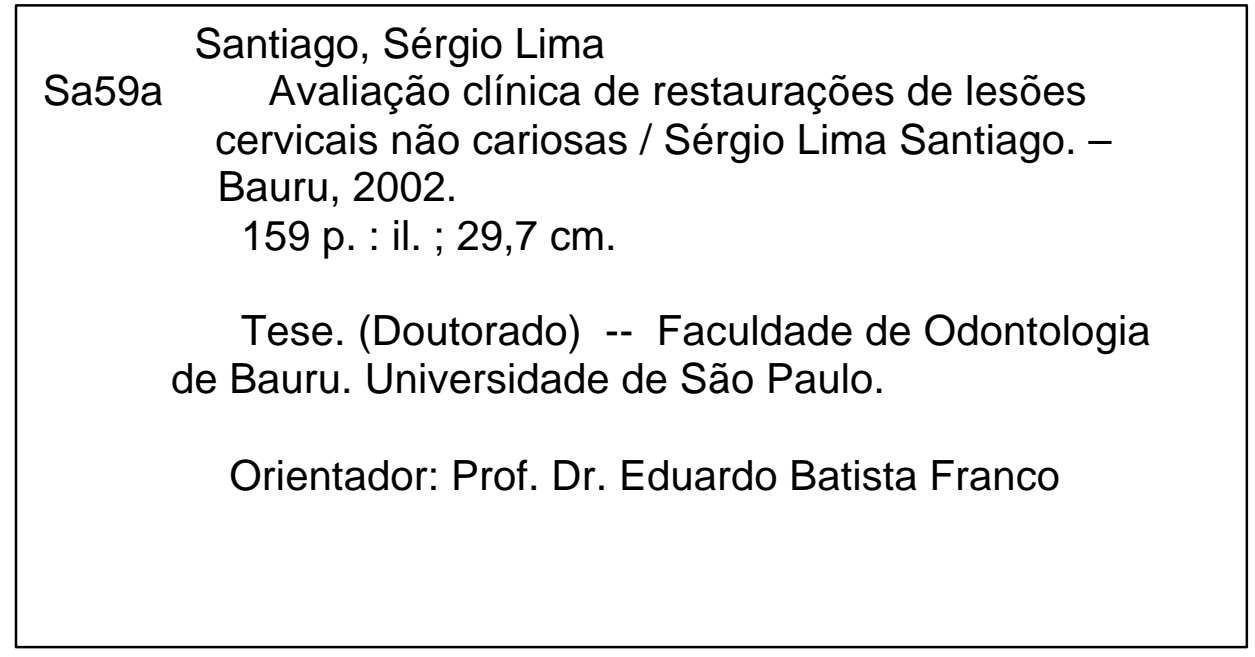

Autorizo, exclusivamente para fins acadêmicos e
científicos, a reprodução total ou parcial desta tese, por
processos fotocopiadores e outros meios eletrônicos.
Assinatura:
Data:

\section{Comitê de Ética da FOB}

$\mathbf{N}^{\circ}$ do Protocolo: Reunião de 24 de fevereiro de 2000

Data: Bauru, $1^{\circ}$ de março de 2000. 


\section{SÉRGIO LIMA SANTIAGO}

01 de Maio de 1969

Fortaleza-CE

Filiação

1987-1991

1994

1994

1996

1996

1997-1999

1999

1999-2002
Nascimento

Danilo de Alencar Santiago e Maria Alba Lima Santiago

Curso de Graduação em Odontologia na Universidade Federal do Ceará - UFC.

Professor Substituto das Disciplinas de Dentística Restauradora Laboratorial e Dentística Operatória Clínica I, do Departamento de Odontologia Restauradora da Universidade Federal do Ceará - UFC.

Professor Auxiliar da Disciplina de Dentística Operatória Clínica I do Departamento de Odontologia Restauradora da Universidade Federal do Ceará - UFC.

Vice-Chefe da Clínica Integrada do Curso de Odontologia da UFC.

Secretário do Centro de Estudos dos Docentes do Curso de Odontologia da UFC.

Curso de Pós-Graduação em Dentística, ao nível de Mestrado na Faculdade de Odontologia de Bauru da Universidade de São Paulo - USP.

Professor Assistente da Disciplina de Dentística Operatória Clínica I do Departamento de Odontologia Restauradora da Universidade Federal do Ceará - UFC.

Curso de Pós-Graduação em Dentística, ao nível de Doutorado na Faculdade de Odontologia de Bauru da Universidade de São Paulo - USP. 
Conselho Regional de Odontologia - CRO-CE. Associação Brasileira de Odontologia Secção Ceará.

Sindicato dos Odontologistas no Estado do Ceará.

Associação dos Docentes da Universidade Federal do Ceará.

Centro de Estudos dos Docentes do Curso de Odontologia da UFC.

Grupo Brasileiro dos Professores de Dentística Sociedade Brasileira de Pesquisa Odontológica.

International Associaton for Dental Research. 


\section{SUMÁRIO}

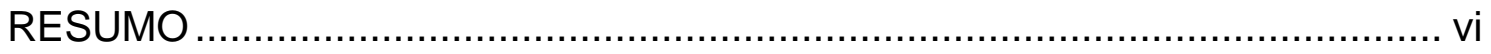

1 INTRODUÇÃO

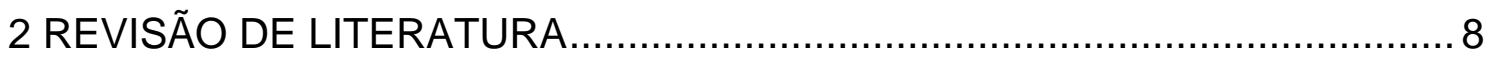

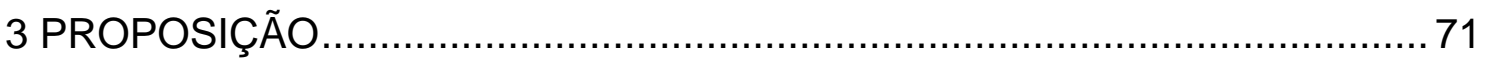

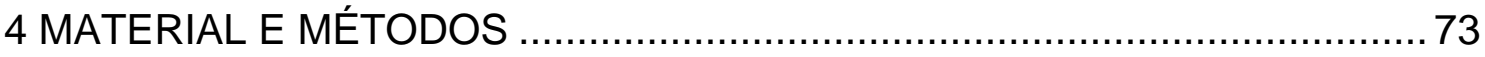

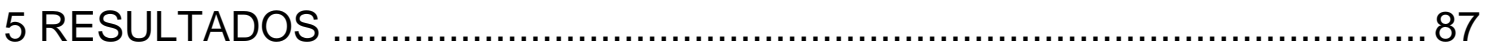

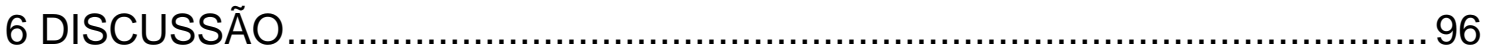

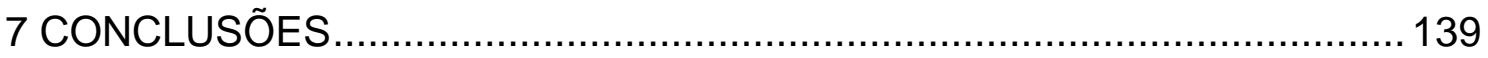

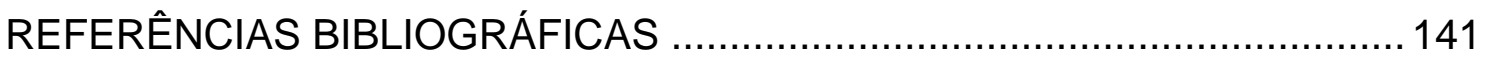

ABSTRACT 


\section{RESUMO}

Avaliou-se o desempenho clínico de um sistema restaurador adesivo (Excite - Tetric Ceram/ Vivadent) e do cimento de ionômero de vidro modificado por resina (Vitremer/ 3M) na restauração de lesões cervicais não cariosas por meio do sistema de avaliação do USPHS modificado. Um total de setenta restaurações, trinta e cinco por material, foi realizado por um único operador em trinta pacientes voluntários com idades de 23 a 68 anos. Previamente à execução das restaurações, foi realizada uma profilaxia com pedra-pomes e água a fim de remover quaisquer resíduos. As lesões cervicais não foram submetidas a qualquer tipo de preparo cavitário, sendo restauradas sob isolamento absoluto e de acordo com as instruções do fabricante. Todas as restaurações foram avaliadas pelo método direto por dois examinadores nos intervalos de tempo estipulados: inicial (baseline), 6 meses, 1 ano e 2 anos usando os critérios de retenção, integridade marginal, descoloração marginal, manutenção da forma anatômica (desgaste), cárie secundária e sensibilidade pós-operatória. Ao final de dois anos, os resultados de restaurações clinicamente satisfatórios (escores Alfa e Bravo) obtidos para a resina composta e cimento de ionômero de vidro modificado por resina foram respectivamente: retenção $(79 \%, 100 \%)$; integridade marginal $(100 \%, 100 \%)$; descoloração marginal (100\%, 100\%); desgaste (96\%, 100\%); cárie secundária $(100 \%, 100 \%)$ e sensibilidade pós-operatória (100\%, 100\%). Os resultados foram submetidos à análise estatística com o teste exato de Fisher ou o teste Quiquadrado de Pearson com nível de significância de $5 \%(p<0,05)$. As comparações intragrupos foram realizadas com o teste de McNemar com nível de significância de $5 \%$. Com base na análise estatística dos resultados concluiu-se que houve diferença estatisticamente significante entre os materiais no critério retenção no período de 2 anos, sendo que nos demais critérios os dois materiais não apresentaram diferenças estatisticamente significante. 


\section{INTRODUÇÃO}

As lesões cervicais não cariosas podem ser definidas como a perda de estrutura dentária na região cervical do dente através de um processo que não envolve bactéria ${ }^{11,83}$. A abrasão e a erosão têm sido amplamente reportadas como os fatores causais das lesões cervicais não cariosas. Entretanto, mais recentemente a flexão do dente tem sido relacionada ao aparecimento dessas lesões, proporcionando um renovado interesse na patogênese da perda de estrutura na região cervical dos dentes ${ }^{65,83}$. Na verdade, a etiologia das lesões cervicais não cariosas é complexa, com erosão, abrasão e abfração apresentando diferentes contribuições na formação e no desenvolvimento das lesões ${ }^{7,66,83}$.

Essas lesões são comumente encontradas na prática clínica em diversas formas, por isso, o entendimento dos fatores etiológicos é importante para determinação de estratégias para o tratamento clínico efetivo ${ }^{44,76,90}$. A prevalência dessas lesões é de 20 a $30 \%$, havendo um aumento com a idade do indivíduo ${ }^{44,128}$. Entretanto, segundo HEYMAN; BAYNE ${ }^{56}$ e GALIEN; KAPLAN; OWENS $^{44}$ o aumento da expectativa de vida e uma maior conservação dos elementos dentários, devido a um maior cuidado de higiene por parte dos pacientes, têm aumentado a incidência dessas lesões.

Muitas lesões cervicais não apresentam sintomatologia nem riscos à saúde dos tecidos circunjacentes e, nem comprometimento estético, devendo o tratamento basear-se na remoção dos fatores causais e monitoramento regular do paciente com vista àestabilização das lesões ${ }^{44}$. Outras, de acordo com o seu estágio de evolução, podem ter uma aparência antiestética, ou ainda serem sensíveis a choques térmicos e/ou escovação. Dessa forma, é necessário levar em consideração o diagnóstico e a etiologia desses tipos de lesões, e indicar o tratamento restaurador somente quando houver presença de hipersensibilidade intolerável, profundidade próxima àpolpa ou enfraquecimento de estrutura dentária, perda de contorno afetando a higiene e saúde periodontal, preenchimento da lesão 
para procedimentos protéticos e comprometimento estético ${ }^{52,53}$. Os benefícios oriundos da restauração das lesões são inúmeros, e dentre eles podemos citar: melhoria da higiene bucal, diminuição da sensibilidade térmica, prevenção de envolvimento pulpar, de abrasão por dentifrício, de erosão ácida e impacção alimentar, bem como melhora a estética e aumenta a resistência do elemento dentário ${ }^{44,48}$.

Do ponto de vista restaurador, as lesões cervicais apresentam um inconveniente, principalmente no que diz respeito àlocalização de suas margens, pois na grande maioria das vezes a margem cervical está determinada em cemento e/ou dentina. Essa característica propicia restaurações mais susceptíveis àmicroinfiltração, ocasionando manchas ou descolorações cavo superficiais, sensibilidade pós-operatória e incidência de lesões cariosas, associando-se ainda o fato da qualidade de união dos sistemas adesivos face ao tipo de substrato nessas lesões que, na grande maioria dos casos, apresenta uma dentina esclerótica e/ou vitrificada.

No decorrer do tempo, vários materiais foram empregados para restauração dessas lesões, dentre eles: ouro em folha, amálgama, cimento de silicato, resinas acrílicas, resinas compostas e cimentos de ionômero de vidro ${ }^{122}$. Os materiais restauradores estéticos de inserção direta como as resinas compostas e os cimentos de ionômero de vidro são os materiais de eleição para a restauração das lesões cervicais não cariosas. GALIEN; KAPLAN; OWENS ${ }^{44}$ relatam que os compósitos oferecem uma solução de tratamento mais duradoura devido ao condicionamento ácido dos substratos dentários, proporcionando uma retenção micromecânica corroborada com a interação química dos sistemas adesivos com a estrutura dentária. Entretanto, JOKSTAD et al ${ }^{63}$. afirmam que as restaurações na região cervical dos dentes não deveriam ser consideradas como permanente, e sim com uma longevidade limitada, pois os materiais restauradores empregados na região cervical são constantemente atingidos pelas resultantes de forças que atuam na superfície oclusal, devendo apresentar características biomecânicas aceitáveis para resistir à tensões. 
Inicialmente, os cimentos de ionômero de vidro foram especialmente idealizados para a restauração das lesões cervicais devido, principalmente, suas características de adesão química à estrutura dentária, liberação de flúor ${ }^{43,73,88}$, biocompatibilidade e coeficiente de expansão térmica linear próximo ao do dente ${ }^{1}$, dentre outras. Os cimentos convencionais não proporcionaram resultados muito favoráveis devido à estética e ao desgaste, apresentavam-se opaco com o tempo e a superfície ficava rugosa e porosa. $O$ controle da umidade também era bastante crítico para os cimentos convencionais, pois a perda ou o ganho de água poderia afetar suas propriedades físicas, químicas e mecânicas ${ }^{126}$. Além disso, a longa reação de presa prejudicava os procedimentos clínicos e afetava adversamente algumas propriedades ${ }^{74}$. Entretanto, os pesquisadores da época acreditava que o desempenho clínico dos cimentos ionoméricos no que diz respeito àretenção e qualida de marginal era superior ao das resinas restauradoras ${ }^{64,124}$.

Os cimentos de ionômero de vidro modificado por resina apresentam melhores propriedades mecânicas que os cimentos convencionais, mas ainda não apresentam as elevadas propriedades físicas dos compósitos ${ }^{1,39}$. O controle do tempo de presa proporcionou uma diminuição da sensibilidade do material aos fenômenos de sinérese e embebição ${ }^{1}$, e acredita-se que houve uma melhoria da adesão àestrutura dentária, da resistência ao desgaste e da adaptação marginal $^{129}$. No que diz respeito àestética, houve uma melhoria em relação aos cimentos convencionais devido ao aumento da translucidez por diferenças das propriedades ópticas dos poliácidos e dos componentes resinosos. Entretanto, a estética, em estudos clínicos de longa duração, tem-se demonstrado inferior àresina composta ${ }^{39,98,129}$.

A evolução da ciência dos materiais dentários permitiu um grande avanço na área dos sistemas adesivos. Esse avanço deveu-se, em parte, ao aumento gradativo do conhecimento a respeito dos substratos sobre os quais os adesivos são aplicados. A melhoria da qualidade de união dos sistemas adesivos 
veio acompanhada de uma maior variação na técnica de aplicação clínica. A necessidade de aplicação de múltiplos passos operatórios resultou em maior complexidade, dificultando o trabalho do profissional e, de certa forma, comprometendo a homogeneidade dos resultados de pesquisas clínicas. Atualmente, nota-se a tendência ao desenvolvimento de sistemas mais simples que associam passos operatórios, no sentido de torná-los menos sensíveis e mais eficientes ao mesmo tempo.

O mecanismo de união dos sistemas adesivos de frasco único baseia-se na desmineralização ácida da dentina e, em seguida, substituição por uma resina ${ }^{24}$. Especificamente, o condicionamento ácido remove os componentes minerais e expõe fibras colágenas que quando corretamente tratadas, permitem que o monômero resinoso penetre por entre elas e, ao converter-se em polímero, ocorra a formação da camada híbrida. Aceita-se, atualmente, que esse é o principal e mais eficiente mecanismo de adesão àdentina ${ }^{99,106,121 .}$

Inúmeros fatores devem ser considerados para a obtenção de resultados satisfatórios quando do emprego dos sistemas adesivos, dentre eles, podemos citar: tipo de substrato dentinário, diferenças regionais, umidade dentinária, tipo de monômero empregado, velocidade de difusão e espessura de camada híbrida. Essas características devem ser conhecidas pelo profissional quando do emprego dos sistemas adesivos para garantir a efetividade de sua aplicação ${ }^{121}$.

Freqüentemente, os testes laboratoriais de adesivos são realizados para avaliar a eficácia dos sistemas restauradores ou para predizer a performance clínica de sistemas adesivos. Os estudos laboratoriais, infelizmente, não refletem o comportamento clínico do material, tornando, entretanto, as avaliações clínicas de materiais restauradores como o método fundamental para comprovar a eficácia dos sistemas adesivos ${ }^{116}$. 
Um dos maiores problemas associados àavaliação clínica de materiais restauradores é, sem dúvida, a padronização do processo e o controle das variáveis, que compreendem o número da amostra, número de pacientes, tipo de preparo, número de clínicos, critério para avaliar os resultados e o tipo de teste estatístico para a análise dos dados.

O primeiro método padronizado para avaliar o desempenho clínico de materiais restauradores foi desenvolvido por RYGE ${ }^{92}$, em 1965, junto ao United States of Public Health Service (USPHS), em São Francisco. O sistema de avaliação USPHS estabelece critérios de avaliação das restaurações baseados em três tipos de julgamentos: clinicamente ideal, clinicamente aceitável, e clinicamente inaceitável. Esses critérios são aplicados a características geralmente associadas ao processo de deterioração que sofre um determinado tipo de material restaurador.

O sistema do USPHS, que ainda é utilizado amplamente hoje em dia, determina a padronização de procedimentos prévios àsua utilização quais sejam: os materiais a serem testados devem ser colocados nas mesmas condições, ou seja, pelo mesmo profissional, em um mesmo paciente e pelo mesmo período de observação. O desempenho de cada restauração é avaliado independentemente, necessitando-se de dois examinadores para se certificar da consistência da avaliação. Em geral, o grau de concordância entre os avaliadores deve ser de pelo menos $85 \%$ e, quando existe desacordo entre os mesmos, em relação aos resultados obtidos, é feita uma discussão para se chegar a um consenso $^{95}$.

A avaliação clínica através do sistema do USPHS baseia-se na inspeção clínica, a partir do exame visual, utilizando-se sonda exploradora e espelho bucal, e pode ser empregado tanto para restaurações metálicas, quanto para restaurações estéticas ${ }^{94}$. 
Os critérios utilizados para restaurações metálicas são: integridade marginal, perda da forma anatômica (desgaste), reincidência de cárie, textura de superfície e descoloração. Por outro lado, para restaurações estéticas, além dos três primeiros critérios descritos anteriormente, analisa-se a reprodução da cor e a descoloração da margem cavo-superficial. A forma de utilização desses critérios baseia-se em uma decisão bipolar de respostas Sim ou Não e posterior organização dos dados em escala ordinal (Alfa, Bravo, Charlie e Delta) ${ }^{94}$.

Algumas modificações foram acrescidas ao sistema do USPHS, a fim de se analisar características clínicas não abordadas inicialmente. A introdução desses novos critérios determinou o sistema de avaliação USPHS modificado, que além de contemplar os critérios descritos no referido sistema, avalia também a sensibilidade pós-operatória, retenção e resistência àfratura ${ }^{68}$.

Devido \&̀ limitações apresentadas pelos métodos diretos, tais como a avaliação subjetiva, obtenção de dados qualitativos, e impossibilidade de reavaliações e documentação das condições clínicas, métodos indiretos de avaliação - modelos e fotografias - podem ser empregados conjuntamente ao método direto (inspeção clínica) com a obtenção de resultados mais precisos ${ }^{68,100}$.

O objetivo do presente estudo foi avaliar o desempenho clínico de um sistema adesivo monocomponente, associado a uma resina composta, na restauração de lesões cervicais não cariosas, comparativamente a um cimento de ionômero de vidro modificado por resina composta, tendo como método de avaliação o sistema USPHS modificado. 


\section{REVISÃO DE LITERATURA}

Os estudos laboratoriais têm o propósito de investigar o comportamento das diferentes técnicas e materiais odontológicos. Por mais fidedigno que seja, esse tipo de avaliação muitas vezes não é capaz de reproduzir as condições bucais no que diz respeito a alterações térmicas, presença de saliva, esforço mastigatório e ainda, não levam em consideração algumas variáveis clínicas como idade, risco àcárie, hábitos alimentares e de higiene bucal.

Perante essas considerações, os estudos clínicos exercem papel fundamental para avaliar o comportamento in vivo das diferentes técnicas e materiais restauradores, possibilitando a obtenção de resultados mais condizentes com a realidade.

Dentre os métodos de avaliação clínica desenvolvidos e de ampla aplicabilidade, o método direto talvez seja o de mais fácil execução e o que apresenta o menor custo operacional. Por outro lado, é dentre todos os métodos de avaliação clínica o mais sujeito a falhas. Desse modo, o método direto tem sido amplamente associado a métodos de avaliação indireta, a fim de se obter uma análise mais precisa e, principalmente, documentada, uma vez que apenas os métodos indiretos permitem a reavaliação da amostragem depois de determinado período de tempo ou uma posterior discussão entre examinadores ou avaliadores.

Atualmente, diante do constante desenvolvimento dos materiais restauradores e do anseio por parte dos pacientes e profissionais em relação àestética, os estudos clínicos estão voltados em sua grande maioria para a avaliação das técnicas e materiais estéticos, tanto para restaurações diretas como indiretas.

Porém, apesar da importância dessas avaliações clínicas, elas encontram-se limitadas no que diz respeito ao custo elevado de algumas 
metodologias, número de hipóteses a serem testadas, tempo de duração do estudo, tipo e número de análises realizadas, dificuldade de obtenção e controle da amostra, obediência aos princípios dos códigos de ética vigentes e ainda, a falta de infraestrutura e centros especializados para melhor padronização dessas pesquisas.

Dessa forma, para um melhor embasamento, o presente trabalho abordará os aspectos inerentes àética em pesquisa, aos sistemas de avaliação clínica de restaurações, a etiologia das lesões cervicais não cariosas e os trabalhos de avaliação clínica desses tipos de lesões.

\subsection{Aspectos Éticos em Pesquisa com Seres humanos}

Os progressos na ciência e tecnologia biomédicas e sua aplicação na prática da medicina provocam um certo grau de ansiedade na população e fazem com que a sociedade se confronte com novos problemas éticos. A sociedade expressa sua preocupação sobre o que teme poderiam ser abusos na investigação científica e na tecnologia biomédica. A investigação tem início com a construção de hipóteses, e essas são testadas em laboratórios, in vitro e em animais. Para que os achados sejam clinicamente úteis, é necessária a realização de experiências em seres humanos; embora sejam cuidadosamente desenhadas, tais pesquisas acarretam algum grau de risco para os participantes. Esse risco justifica-se não por qualquer benefício pessoal ao pesquisador ou àinstituição pesquisadora, mas sim pelo seu benefício aos participantes envolvidos, e por sua contribuição potencial ao conhecimento humano, ao alívio do sofrimento ou ao prolongamento da vida ${ }^{8}$. De acordo com HOSSNE $^{59}$, em 2001, o interesse crescente sobre os aspectos éticos em pesquisa, reside no fato de que a cada dia afloram deslizes éticos, muitas vezes graves, nas diversas atividades humanas, e progressivamente têm-se desenvolvido o sentimento de cidadania, calcado na ética.

Em 1947 surgiu o primeiro texto de referência em bioética de alcance internacional que foi o código de Nuremberg. Esse código enfatizava a absoluta necessidade do consentimento voluntário do indivíduo submetido ̀̀ 
experiências biomédicas. Essa exigência passaria a ser base de todo o sistema legal da bioética, constituindo o instrumento que permitia a distribuição entre uma pesquisa realizada em condições democráticas, de uma pesquisa realizada de modo autoritário ou do regime totalitário. Além disso, introduziria a obrigatoriedade dos prérequisitos científicos, apoiada na soberania da responsabilidade ética do profissional $^{2}$.

$\mathrm{Na}$ odontologia podemos citar como exemplo o clássico estudo sobre incidência da cárie dentária, realizado em um hospital para doentes metais em VIPEHOLM na Suécia, em 1954 onde indivíduos consumiam dietas acrescidas de sacarose em suas diversas formulações, provocando dessa forma o aparecimento da doença cárie, sem o consentimento voluntário desses indivíduos sujeitos do experimento, ou dos seus representantes legais, não havendo na literatura relatos a respeito do reparo aos danos causados.

A declaração de Helsinque de 1964, revista em Tóquio em 1975, traria três avanços significativos: primeiro estabeleceria, que na contabilização dos riscos, os interesses do indivíduo devem prevalecer sobre os interesses da ciência e, até mesmo sobre os da sociedade. Segundo, definindo que o principio da obrigatoriedade do consentimento informado necessariamente deve conduzir os responsáveis pela experimentação a fazer uma apreciação diferenciada daqueles indivíduos que se encontram nas situações específicas de dependência e incapacidade. Terceiro, estabelecendo a obrigatoriedade de submeter todo protocolo de pesquisa a uma comissão de ética independente e definindo as garantias específicas a serem observadas nos casos de ensaios sem benefícios terapêuticos diretos. Finalmente, definiu-se que o não cumprimento desses princípios éticos deveria impedir a publicação dos resultados da pesquisa ${ }^{2}$.

Em 1981, outra declaração sobre ética foi elaborada, denominada declaração de Manila que foi realizada pela Organização Mundial de Saúde (OMS) e Conselho das Organizações internacionais das Ciências Médicas (CIOMS), acrescentando uma interação importante na relação ciência ética, a saber: 
não é possível estabelecer uma clara demarcação entre apreciação cientifica e apreciação ética, pois uma experiência com seres humanos que não tenha valor científico é inteiramente contrária àética. Embora a Declaração de Manila tenha representado um grande avanço, por ter uniformizado as regras éticas a serem observadas pelos pesquisadores e instituições estrangeiras nos países em desenvolvimento, ela não possui em seu contexto os problemas éticos suscitados pela questão do direito ao desenvolvimento desses países. Essa questão ocupa o centro de importantes controvérsias presentes em diversos foros de negociações das relações internacionais, sobretudo econômicas e comerciais ${ }^{2}$.

Segundo a Organização Mundial de Saúde (OMS), toda pesquisa envolvendo seres humanos deve ser conduzida de acordo com três princípios éticos básicos: o respeito pela pessoa, beneficência e justiça. O respeito pela pessoa incorpora duas considerações éticas fundamentais, respeito pela autonomia das pessoas capazes de decidir livremente sobre sua participação na pesquisa e proteção contra danos ou abusos daqueles com autonomia alterada ou diminuída. O segundo princípio refere-se àbeneficência, que é a o brigação ética da maximização de benefícios e minimização dos danos ou prejuízos; e finalmente, o terceiro princípio representado pela justiça a qual determina a obrigação ética de tratar cada pessoa de acordo com o que é normalmente certo e adequado, ou seja, dar a cada pessoa o que lhe é devido ${ }^{2,91}$.

De acordo com RAMOS ${ }^{91}$, em 1996, esses princípios representam o resultado do aprofundamento de diferentes documentos propostos em conferências promovidas pela Organização Mundial da Saúde: Nuremberg, 1947, Helsinque, em 1964, Tóquio, em 1975, Veneza, em 1983, Hong Kong, em 1989 , dentre outras.

No Brasil em 1988 o Conselho Nacional de Saúde, aprovou através da Resolução CNS no 1/88, as primeiras normas nacionais sobre ética na pesquisa em seres humanos, as quais representaram, à época, considerável e importante avanço. Dentre as diretrizes existentes, vale ressaltar a necessidade de 
que, em instituições de pesquisa, existam comitês de ética que possam zelar pelo bom andamento ético das pesquisas ${ }^{91}$. Após sete anos de sua aplicação, na Comissão Intersetorial de Ciência e Tecnologia, o CNS decidiu rever a resolução no $1 / 88$ com objetivo de atualizá-la devido ao grande desenvolvimento cientifico surgido após a sua publicação.

A partir de 1995, o Conselho Nacional de Saúde identificou a necessidade de construir um sistema capaz de acompanhar as pesquisas em seres humanos no país, e em outubro de 1996, foram aprovadas as diretrizes e normas regulamentadoras de pesquisas envolvendo seres humanos, consignadas na Resolução CNS 196/96. Essa resolução define a abrangência da norma e orienta sobre aspectos éticos a serem observados nos protocolos de pesquisa, contempla ainda aspectos operacionais quanto àestruturação de um sistema em rede, para o acompanhamento da ética na pesquisa. Cria instâncias institucionais, os CEP's (Comitês de Ética em Pesquisa) e a Comissão Nacional de Ética em Pesquisa (CONEP), vinculada ao Conselho Nacional de Saúde (CNS), estabelecendo as respectivas atribuições e o fluxo de aprovação dos projetos ${ }^{42}$. Entretanto, o papel dos comitês não é só o de fiscalizar o que os pesquisadores se propõem a realizar; antes, deve representar um espaço de aprofundamento e difusão dos princípios éticos que norteiam a pesquisa na instituição, cumprindo, assim, uma função educativa para com aqueles que desejam ser ajudados na retomada de uma moralidade verdadeira na pesquisa, o que, aliás, também se constitui no objetivo maior da Bioética como ciência ${ }^{91}$.

A aprovação das diretrizes e normas regulamentadoras de pesquisas em seres humanos, através da resolução CNS no 196/96 de 10 de outubro de 1996, representa, portanto, o passo inicial de características gerais do processo de revisão das normas brasileiras de ética em pesquisas em seres humanos. Essa resolução tem por mérito ser o instrumento de grande importância para que o CNS possa acompanhar o processo de desenvolvimento e incorporação cientifica e tecnológica na área da saúde visando ao cumprimento de padrões éticos compatíveis com o desenvolvimento sócio-cultural do país. 


\subsection{MÉtodos de AVALIAÇÃo ClínICA}

RYGE $^{92}$, em 1965, sentindo a dificuldade de realizar estudos clínicos, estabeleceu alguns critérios para a avaliação de materiais restauradores. Ressaltou a importância da utilização de um grupo controle na comparação de resultados de uma avaliação clínica. Os materiais a serem testados devem ser colocados nas mesmas condições, pelo mesmo profissional, no mesmo paciente e avaliados por um mesmo período de observação. Preconizou que o número de ideal de restaurações é de 50 para cada material, e que a calibração dos avaliadores é imprescindível. Ficou estabelecido um critério para a avaliação de restaurações baseado em três tipos de julgamento: clinicamente ideal, clinicamente aceitável, e clinicamente inaceitável. Esses julgamentos são aplicados a características geralmente associadas ao processo de deterioração do material restaurador. Esse critério de avaliação clínica foi desenvolvido através do Serviço de Saúde Pública dos Estados Unidos (United States Public Health Service - USPHS) e ficou mundialmente conhecido como sistema de avaliação USPHS.

RYGE; CVAR $^{93}$, em 1966, comentaram a necessidade de testar clinicamente os materiais restauradores, uma vez que os testes de laboratório apesar de importantes na seleção de novos materiais não fornecem dados conclusivos sobre vários aspectos do comportamento dos materiais quando são expostos aos rigores da cavidade oral. Recomendaram a colocação dos materiais aos pares e a necessidade da eliminação do maior número possível de variáveis. É de fundamental importância a catalogação dos dados dos pacientes, das restaurações executadas e das avaliações.

A American Dental Association, em 1972, através do Conselho de materiais dentários, reconheceu a importância da padronização de critérios de avaliação de estudos clínicos, incluindo o estabelecimento de protocolos e métodos de registro das avaliações. Essas recomendações incluem definições de termos relacionados àtomada de registro, tipo de pessoal e treinamento do pessoal 
envolvido em pesquisas clínicas. Recomendou também, uma série de procedimentos padronizados para serem utilizados na execução de um protocolo de pesquisa. No delineamento do estudo, cada grupo de fatores deve ser cuidadosa e criticamente avaliado, bem como a relevância e o objetivo do estudo devem ser bem definidos. A anotação de dados não relevantes pode consumir tempo desnecessariamente e confundir o estudo. Após o estabelecimento dos fatores a serem examinados, resta definir os critérios pelos quais serão avaliados. Para cada fator, um número mínimo de critérios deve ser estabelecido, estando de acordo com o objetivo do estudo. O sistema de apresentar ao pesquisador uma série de decisões bipolares, baseadas em respostas de sim ou não, apresenta-se bastante efetivo em estudos clínicos. As escalas de avaliação ou procedimentos de classificação são recomendados para a avaliação clínica de materiais restauradores. Os dados referentes aos procedimentos clínicos devem ser anotados criteriosamente, descrevendo a manipulação e inserção do material na cavidade e procedimentos de acabamento e polimento. Os registros de avaliação são usados para anotar os dados referentes à avaliação inicial (baseline) e avaliações subsequentes de acordo com os critérios selecionados. Com relação ao pessoal envolvido no projeto, além do responsável direto, é necessário a presença do pesquisador clínico, o qual realizará os procedimentos operatórios, um assistente que tem a função de auxiliar o pesquisador na preparação dos instrumentos e materiais a serem utilizados na pesquisa e um anotador, o qual é responsável pelo registro e armazenamento dos dados da pesquisa. $O$ anotador deve estar familiarizado com o protocolo e com os procedimentos executados pelo operador e assistente, devendo ser capaz de detectar qualquer desvio dos mesmos. Quanto ao treinamento do pessoal, quando mais de um pesquisador trabalha no projeto, é necessário que estejam calibrados quanto àexecução e registro de dados. Sempre que possível, modelos de referência devem ser desenvolvidos para o treinamento e calibração do pessoal.

A adoção de critérios para a avaliação clínica de materiais restauradores foi abordada por CVAR; RYGE $^{27}$, em 1973, que elaboraram uma escala de avaliação para vários fatores que foram considerados relevantes na 
objetividade da avaliação clínica. A calibração de profissionais foi conseguida através de um treinamento cujos resultados foram comparados no sentido de se obter julgamentos consistentes. Apenas quando os testes indicaram que os examinadores eram capazes de duplicar suas próprias respostas e os julgamentos de outros examinadores, dentro de um determinado nível de aceitabilidade, é que os critérios passaram a ser adotados. Experimentos subsequentes, com as escalas de avaliação aplicadas em estudos clínicos, levaram àconsolidação dos critérios para restaurações de dentes anteriores e posteriores. As escalas de avaliação foram estabelecidas para os seguintes aspectos: cor, descoloração marginal, forma anatômica, adaptação marginal e cárie.

O desenvolvimento e a introdução de um novo método para classificação da qualidade das restaurações foi testado por RYGE; SNYDER ${ }^{95}$, em 1973. Foram adotadas duas classificações, satisfatória ou não aceitável; sendo que cada classificação apresentava duas subclassificações. Para o julgamento satisfatório, dependo do estado da restauração, utilizava-se: "está de acordo com os padrões" ou "observe-se na próxima visita". Para o julgamento não aceitável, as subclassificações eram: "substituir por prevenção" ou "necessidade de substituição". Dois profissionais realizaram avaliações clínicas onde examinaram 991 restaurações e reexaminaram 109 dessas restaurações, a fim de checar a concordância intraexaminador. Aproximadamente $98 \%$ das restaurações foram classificadas como satisfatórias, sendo que $62 \%$ dentro da categoria (está de acordo com os padrões). A concordância inter-examinador foi de $92 \%$ e a concordância intra-examindor de $89 \%$. Os autores destacaram a importância do treinamento prévio dos examinadores para a obtenção de um índice de concordância igual ou maior que $85 \%$. Nos casos de discordância, é recomendado um reexame conjunto da restauração para se chegar a um consenso.

GORDON $^{47}$, em 1974, estabeleceu os critérios de avaliação da California Dental Association (CDA), com o objetivo de que a qualidade de trabalho executado pelos cirurgiões-dentistas, abrangendo várias especialidades da Odontologia, fosse avaliada por profissionais clínicos e não por burocratas. As 
características mais comumente avaliadas em relação àqualidade das restaurações são: textura superficial, cor, forma anatômica e integridade marginal. O sistema de classificação CDA apresenta duas categorias principais (satisfatória e não aceitável), que em outras palavras significam se as restaurações devem ser mantidas ou substituídas. A classificação satisfatória inclui duas subcategorias, sendo a primeira o nível de excelência, que apresenta expectativa de longa durabilidade, protegendo o dente e estruturas circunvizinhas, e a segunda o nível de aceitabilidade, apresentando um ou mais aspectos que a distanciam das condições ideais. As restaurações classificadas como não aceitáveis também podem ser subdivididas em duas subcategorias: substituição por prevenção de danos futuros aos dentes ou tecidos circunvizinhos e substituição imediata, quando esses danos já estão presentes.

ELDERTON $^{31}$, em 1976, realizou uma revisão da literatura sobre o que tem sido feito no sentido de definir e classificar as causas de falhas das restaurações e, para estimar a contribuição de cada um dos trabalhos sobre um modelo amplo de causa de falhas. $O$ autor concluiu que uma grande variedade de razões tem sido reportadas para explicar o insucesso das restaurações. Destacou, todavia que, os trabalhos de pesquisa não têm sempre diferenciado adequadamente entre as causas verdadeiras de falhas e as manifestações ou efeitos os quais atuam como critérios para julgamentos das mesmas. O julgamento clínico de causas de falhas de restaurações está sujeito a consideráveis diferenças de opinião, confirmando sua natureza subjetiva.

ELDERTON $^{32}$, em 1976, realizou uma revisão da literatura sobre a prevalência de falhas das restaurações na qual observou que, enquanto os trabalhos sobre prevalência de falhas variavam consideravelmente, de um modo geral eles demonstraram que cerca de uma entre três presentes, em qualquer tempo, é insatisfatória e de alguma maneira falhou ao ser analisada quanto a um critério comumente usado para determinar o sucesso. Desse modo, ao invés de assumirmos a visão gerada pelos livros texto de que um tratamento restaurador normalmente será bem sucedido em longo prazo, parece que seria mais preciso 
assumir que toda restauração apresenta uma grande chance de falhar dentro de poucos anos.

ELDERTON $^{33}$, em 1977, relatou que a maioria das avaliações da qualidade das restaurações é inteiramente subjetiva e envolvem instrumentos de diagnóstico clínico padronizado. Entretanto, mais recentemente têm-se obtido um aumento da demanda de métodos mais apurados e confiáveis. Esforços têm sido desenvolvidos no sentido da padronização dos julgamentos clínicos através da provisão de vários sistemas de critérios sobre os quais eles se baseiam. Enquanto isto tem melhorado a utilidade das avaliações, ao mesmo tempo tem permanecido largamente subjetiva. Além disso, a eficácia do uso de critérios particular é por si abertos a questionamentos. Claramente, as avaliações feitas desta maneira contam com julgamentos individuais de profissionais e são, por consequência, subjetivos. Através do uso de métodos mais complexos de avaliação, frequentemente no campo de pesquisa dos materiais restauradores, as avaliações têm sido conduzidas sobre várias características restaurações e um contexto de fatores conhecidos que podem influenciar ou manifestar-se na sua qualidade. Entretanto, a verdadeira significância desses conhecimentos em termos de comportamento clínico e, por consequência da qualidade limitada das restaurações, ainda está por ser estabelecida, pois muitos dos estudos têm sido conduzidos fora da realidade das condições bucais. Notadamente, poucos estudos têm sido conduzidos neste sentido, assim como poucas mensurações de alguns fatores que afetam as qualidades das restaurações têm sido reportadas.

\section{Em 1977, STANFORD; RYGE ${ }^{101}$ descreveram uma} sequência de critérios que devem ser levados em consideração na elaboração de um protocolo de pesquisa clínica, ou seja, todos os fatores que devem ser abordados no delineamento de uma pesquisa. Esses fatores incluem: 1- A problematização do estudo; 2- A determinação dos objetivos e o estabelecimento de hipóteses; 3- A amostragem da pesquisa, 4- Procedimentos prévios, os métodos e as circunstâncias para conduzir a pesquisa; 5- Métodos de avaliação e coleta dos dados; 6- Análise estatística dos dados; 7- Orçamento; 8- cronograma de atividades; 


\section{9- Publicação.}

RYGE $^{94}$, em 1980, observou que as escalas de classificação desenvolvidas para a avaliação clínica são do tipo ordinal e que para cada classificação, certos critérios têm sido formulados para possibilitar ao examinador distinguir entre características as quais são consideradas clinicamente significantes. O uso de escalas de classificação consiste de uma progressão de decisões bipolares, levando à classificação das restaurações a serem avaliadas. Esses critérios e consequentes classificações refletem uma significância clínica ao invés de uma significância estatística. A avaliação clínica através do sistema do USPHS baseia-se na inspeção clínica, a partir do exame visual, utilizando-se sonda exploradora e espelho bucal, e pode ser empregado tanto para restaurações metálicas, quanto para restaurações estéticas. Os critérios utilizados para restaurações metálicas são: integridade marginal, perda da forma anatômica (desgaste), reincidência de cárie, textura de superfície e descoloração. Por outro lado, para restaurações estéticas, além dos três primeiros critérios descritos anteriormente, analisa-se a reprodução da cor e a descoloração da margem cavosuperficial. A forma de utilização desses critérios baseia-se em uma decisão bipolar de respostas Sim ou Não e posterior organização dos dados em escala ordinal (Alfa, Bravo, Charlie e Delta). Algumas regras devem ser seguidas para a classificação no sistema: dois profissionais fazem avaliações independentes; cada profissional deve avaliar cada característica; a característica que recebe a classificação mais baixa determina a categoria; se há concordância entre os profissionais quanto à classificação, essa é considerada final; se há discordância na classificação, os profissionais devem examinar novamente e juntos chegarem a uma decisão final.

Em 1980, ERIKSEN ${ }^{34}$, enfatizou a importância de métodos fidedignos para a avaliação clínica de restaurações. O sistema Ryge é provavelmente o método mais conhecido para a avaliação clínica direta de restaurações. Foi relatada a aplicação de sistemas diretos e indiretos de avaliação para determinadas características, tais como: adaptação marginal, reincidência de cárie, rugosidade superficial, descoloração marginal e desgaste oclusal. $\mathrm{O}$ autor 
concluiu que ambos os estudos eram necessários para a obtenção de uma visão completa e balanceada das propriedades clínicas das resinas compostas.

\section{FEDERATION DENTAIRE INTERNATIONAL ${ }^{35}$, em 1982,} recomendaram fatores que devem ser levados em consideração no delineamento de uma pesquisa clínica. A expressão - fatores a serem considerados - implica que nem todos os fatores traçados serão utilizados em qualquer projeto e que a extensão da utilização de certos fatores específicos devem ser feitos sob medida para um determinado projeto. Esses fatores têm sido delineados primeiramente para auxiliar o pesquisador em planejar, iniciar e dar seguimento a um projeto de pesquisa clínica. A identificação do problema é o passo principal para a determinação do que será estudado, as hipóteses a serem testadas e os objetivos a serem cumpridos na metodologia devem estar contemplados de maneira elucidativa. O conhecimento de trabalhos anteriores com embasamento na literatura deve dar suporte ao projeto. A metodologia deve ser bem delineada e consistir de: critérios de seleção e exclusão dos pacientes, definindo a população participante; possível fonte de pacientes participante pode incluir escolas, instituições e grupos organizados tais como bombeiros e policiais. Deve-se enfatizar a importância da cooperação das pessoas e organizações envolvidas, bem como a seleção de pacientes que possuam estabilidade geográfica e que estejam profundamente motivados na participação do estudo até àconclusão. Os pacientes devem ser informados dos riscos e benefícios e significância de sua participação. O conhecimento do material a ser utilizado, tais como composição, propriedades, uso, manipulação, dentre outros aspectos, devem ser relatados. Por fim, o planejamento estatístico é de suma importância para a comprovação dos resultados obtidos, através da utilização de testes estatísticos compatíveis com o modelo experimental. No que diz respeito aos aspectos administrativos, o coordenador do projeto é o principal responsável pelo bom andamento do experimento, devendo ter o conhecimento tanto da ciência clínica quanto dos materiais, sendo de extrema importância sua familiarização com os requisitos éticos e legais. 
SMALES $^{100}$, em 1983, avaliaram comparativamente, alguns métodos de avaliação clínica para analisar sua capacidade em diferenciar os vários graus de deterioração das restaurações. Cinquenta restaurações de Classe I à amálgama e cinquenta restaurações de Classes III, IV e V de resina composta com até 8 anos de confecção, foram examinadas através de 4 métodos. $O$ autor utilizou um método direto (Método $A$ ), com critérios subjetivos, baseados nos critérios desenvolvidos por RYGE e colaboradores. Esse método direto foi comparado com três outros métodos indiretos, todos baseados em tomadas fotográficas com filmes de diapositivos coloridos, variando o grau de aumento (1X-método B e $2 \mathrm{X}$ - métodos $\mathrm{C}$ e D), realizadas no momento do exame clínico direto. Todos os diapositivos foram examinados sem projeção, por meio de um negatoscópio. $O$ autor concluiu que o método $D$, com o aumento de duas vezes e uma escala linear detecta facilmente pequenas diferenças entre as restaurações quanto a todas as características clínicas. Os métodos A, B e C não apresentaram diferença significantes entre as restaurações.

O uso de estudos clínicos para demonstrar a eficácia de materiais restauradores tem aumentado substancialmente devido ànecessidade de evidências clínicas para a aprovação de materiais pelos programas de aceitação. Dessa forma, JACOBSEN ${ }^{62}$, em 1988, realizou uma revisão de literatura a cerca do delineamento de estudos clínicos. Definiu que os estudos clínicos podem ser classificados como explanatórios, onde o material que está sendo avaliado é utilizado em condições controladas e com acompanhamentos periódicos, ou estudos pragmáticos, em que os materiais são avaliados em condições não controladas, também chamadas de pesquisa de "campo". O autor afirma que experimentos bem delineados aumentam a objetividade do estudo, reduzindo as interferências criadas pelo operador ou paciente, permitindo um melhor detalhamento das características do material. Estudos conduzidos em vários centros de pesquisa com a utilização do mesmo protocolo são preferíveis a estudos de um único centro. As restaurações devem ser realizadas aos pares, onde um preparo receberá o material a ser testado e o outro deve ser restaurado com o material controle. Os experimentos não pariados, em que cada paciente recebe um material (teste ou controle) são mais 
fáceis de serem conduzidos, sendo entretanto, mais difíceis de serem analisados, necessitando-se de uma amostragem maior e uma menor variabilidade de condições (tamanho da cavidade, posição do dente, exposição a cargas). Os estudos explanatórios apresentam-se como o melhor indicador do potencial de um novo material. No que diz respeito à amostragem, os pacientes devem participar do estudo voluntariamente, e estar disponíveis nos períodos de avaliação e também motivados a participar. Os critérios de inclusão no estudo são: boa higiene oral, cavidades pequenas ou moderadas, ausência de contatos prematuros, baixo índice de cárie, dentre outros aspectos. Outro fator de extrema importância no delineamento de uma pesquisa clínica é a formulação de hipóteses. As hipóteses podem ser tão simples quanto: "as resinas são melhores que o amálgama para cavidades de Classe II" ou precisas como - "o material microparticulado apresenta maior índice de desgaste que o material híbrido". Reporta ainda sobre o poder do teste estatístico o qual deve apresentar um mínimo de 25 restaurações ao final de três anos e 20 restaurações ao final de cinco anos, entretanto não recomenda nenhum teste. $O$ autor finaliza a revisão afirmando que a relação entre os testes laboratoriais e as performances clínicas permanece vagas e essa é provavelmente a área de maior desafio para os pesquisadores clínicos e laboratoriais.

CHADWICK et al. ${ }^{26}$, em 1991, reportaram a respeito de um estudo comparativo com dois métodos de avaliação, um método clínico (critérios USPHS modificado), e um método fotogramétrico para monitorar o desgaste de restaurações. Avaliaram o desgaste oclusal de dois materiais (resina composta e cimento ionomérico) tendo o amálgama como controle. Os autores observaram que as restaurações, quando avaliadas pelo método direto, não apresentaram diferenças estatisticamente significantes quanto aos critérios de forma anatômica e adaptação marginal. Todavia, quando do emprego do método indireto, foram encontradas diferenças na performance dos materiais estudados. 
Em 1996, a AMERICAN DENTAL ASSOCIATION ${ }^{5}$, através de seu conselho científico, estabeleceu algumas normas para a apreciação e julgamento de um novo material por meio de avaliações clínicas. O mínimo de duas avaliações clínicas independentes deve ser encaminhado, requerendo-se um período de observação de dois anos para a aceitação provisória e de quatro anos para a aceitação definitiva. Embora não seja exigido, deve-se dar preferência a modelos de estudo pariados, onde cada paciente recebe o material a ser testado e um controle de reconhecida eficácia. Esse estudo minimiza os efeitos da diferença entre os indivíduos, e só é requerido quando o fabricante deseja mostrar eqüivalência entre materiais restauradores. Com relação ao número de restaurações, deve-se realizar um mínimo de trinta restaurações, sendo que não pode realizar mais que três restaurações num mesmo indivíduo. O número de indivíduos participantes do estudo não pode ser menor que 25 pacientes no baseline, 20 pacientes aos dois anos e 15 pacientes aos quatro anos. Devendo-se apresentar uma distribuição equivalente entre as faixas etárias dos pacientes e um número igual de pacientes em relação ao gênero. A avaliação clínica deve incluir todas as características comumente empregadas para julgar a aceitação clínica de uma determinada restauração. A utilização de fotografias, imagens digitais, modelos de gesso ou réplicas em resina epóxica facilitam a avaliação de mudanças no decorrer do tempo.

Em 2000, ZAVRAS; GYPSON ${ }^{132}$ descreveram os processos científicos e regimentais que envolvem uma pesquisa clínica. Através da descrição da metodologia da investigação clínica, eles afirmam que o desenvolvimento do protocolo consiste do primeiro passo na condução dos trabalhos. Todo protocolo deve conter informações sobre a proteção e a segurança dos sujeitos envolvidos na pesquisa e a qualidade dos dados gerados pelo experimento. $O$ artigo relata ainda as obrigações do pessoal envolvido na pesquisa, como o coordenador da pesquisa e os pesquisadores. 
Em 2001, JOAKSTAD et al. $^{63}$ realizaram uma extensa revisão de literatura a cerca dos aspectos envolvidos nas pesquisas clínicas. Essa revisão esclarece que os estudos clínicos geralmente são conduzidos sob ótimas condições e, dessa forma, sugerem diferenças entre os dados destes estudos e os obtidos na prática clínica geral. As avaliações da qualidade de restaurações são influenciadas pelo prognóstico do dente e não pelo nível de excelência técnica obtida. Conseqüentemente, as avaliações clínicas são válidas somente quando conduzidas por profissionais com o conhecimento da história clínica do paciente, através da realização de estudos explanatórios, os quais se têm o controle de variáveis que possam interferir nos resultados, e, além disso, as observações periódicas do paciente possibilita o diagnóstico mais preciso da qualidade ou falha do material em estudo. Em relação aos sistemas de avaliação clínica, os autores afirmam que os métodos diretos $\mathrm{e}$ indiretos de avaliação da qualidade das restaurações detêm-se em características específicas das restaurações mais do que no seu estado geral. Métodos de avaliação indiretos escondem a avaliação global da restauração, devendo-se dar preferência a avaliações clínicas, sendo ou não subjetivas ou objetivas, de acordo com precisos critérios específicos.

\subsection{Etiologia das Lesões Cervicais não Cariosas}

\section{Em 1972, XHONGA; WOLCOTT; SOGNNAES ${ }^{127}$}

idealizaram um estudo clínico para medir a progressão de lesões erosivas em dentes que não receberam qualquer tipo de tratamento, em dentes que receberam aplicação tópica de flúor e em dentes restaurados. Nesse estudo foram utilizados 14 pacientes de ambos os sexos, com idades de 26 a 65 anos que apresentavam lesões erosivas. As medições das lesões erosivas foram realizadas no início e no final do período de observação, utilizando a técnica de replica com aumento de 20 vezes. Cinquenta e sete lesões não receberam qualquer tipo de tratamento, 56 lesões receberam aplicação tópica de flúor e 42 lesões foram restauradas com ouro em folha, amálgama e resina acrílica. Ao final de cinco meses de observação, a progressão das lesões foi de aproximadamente $7 \mu$ por semana para os dentes não tratados e para os que receberam aplicação tópica de flúor. A restauração das 
lesões fez com que houvesse uma diminuição do processo de desgaste pela metade, entretanto, o padrão de desgaste pôde ser observado na superfície dos materiais restauradores e em áreas adjacentes àrestauração, sugerindo a existência de fatores físicos e mecânicos no desenvolvimento desses tipos de lesões.

A alta prevalência de perda de estrutura dentária na junção cemento-esmalte em decorrência de erosão, abrasão e outros fatores não cariogênicos, a grande variedade de agentes etiológicos envolvidos nesse fenômeno, bem como a falta de uma relação entre causa e efeito, levaram RADENTZ; BARNES; CUTRIGHT ${ }^{90}$, em 1976, a avaliar os fatores que podem contribuir para o início e desenvolvimento desse processo. Os autores realizaram um estudo com 80 pacientes, com média de idade de 24 anos, dos quais 66 eram do sexo masculino e 14 do sexo feminino. Observaram que 50\% desses indivíduos apresentavam alguma evidência de lesão cervical não cariosa, sendo que os dentes mais afetados foram os primeiros molares superiores com $17,3 \%$ da amostra, seguidos dos primeiros pré-molares superiores com $13,3 \%$ e dos segundos prémolares inferiores, com $12,1 \%$. A técnica e a frequência de escovação bem como a quantidade de dentifrício utilizadas por indivíduo foram avaliadas e relacionadas a outros fatores como sexo, raça e o uso da mão direita ou esquerda durante a escovação. Os resultados não mostraram qualquer correlação entre as lesões cervicais cariosas e esses fatores. Apenas uma pequena relação entre a quantidade de dentifrício utilizada e a ocorrência de lesões pôde ser observada.

BRADY; WOOD ${ }^{17}$, em 1977, considerando a freqüente associação entre lesões cervicais e forças abrasivas, especialmente entre indivíduos que praticam higiene oral entusiasticamente, propuseram estudar essas lesões entre 900 dentistas. Os autores constataram uma prevalência de 5,3\%, atingindo caninos, pré-molares e primeiros molares. Os primeiros pré-molares foram os dentes mais afetados com $62 \%$ dos casos, seguido dos segundo pré-molares com $19 \%$, dos caninos com $12 \%$ e dos primeiros molares com $6 \%$. Os autores concluíram que existem dois mecanismos de ação na formação de lesões cervicais. O primeiro resulta em um defeito com características angulares, profundo e com margens 
nítidas e associado com tensão oclusal, e interação colágeno-apatita na dentina. O segundo com morfologia arredondada, raso e sem limites nítidos, resultando de simples abrasão física por fluídos orais e limpeza mecânica.

McCOY ${ }^{77}$, em 1983, considerou existir evidências clínicas suficientes para negar a popular teoria da friç̧ão por escovação na etiologia das lesões cervicais ainda em voga naquela época. Não encontrando suporte na literatura para a hipótese de que os defeitos angulares cervicais eram resultado de fadiga devido àmovimentação do dente, o autor submeteu uma série de diapositivos com exemplos clínicos dessas lesões cervicais àapreciação de cientistas com a formação em engenharia. Os engenheiros concluíram que embora tivessem pouco conhecimento em bruxismo, concordaram que os defeitos na região cervical eram óbvios exemplos de fadiga dos tecidos mineralizados. Trabalhos conduzidos por um grupo de engenheiros, através do método de elemento finito, concluíram que as forças de tensão na área gengival são suficientemente fortes para deslocar os prismas de esmalte dessas regiões. Eles também observaram que 0 alto estresse nessa região é o responsável pela dor comumente relatada em pacientes que receberam tratamento restaurador na região cervical.

LEE; EAKLE ${ }^{66}$, em 1984, apresentaram a hipótese de que as lesões erosivas tinham como fator etiológico primário as tensões de tração causadas pela mastigação e má-oclusão, e que fatores locais como escovação ou ácidos desempenham um papel secundário na dissolução da estrutura dentária. Os autores consideraram que a variada morfologia das lesões cervicais erosivas, assim chamadas por falta de melhor terminologia, e a falta de entendimento sobre sua etiologia provocam confusões com erosões provocadas por ácidos e abrasão por escovação. Alguns estudos têm mostrado que cargas excêntricas aplicadas à superfície oclusal geram estresse que se concentram na região cervical. Quando a oclusão é ideal, as forças mastigatórias são primeiramente direcionadas ao longo eixo do dente, resultando em dissipação e mínima distorção da dentina e cristais de hidroxiapatita. Quando a oclusão não é ideal, ocorre a formação de forças laterais que flexionam o dente, criando dois tipos de tensões na estrutura dentária. A 
primeira de compressão, localizada no lado para o qual o dente está sendo flexionado, a segunda de tração que atua no lado contrário ao da compressão. A região sob maior tensão de tração é a próxima ao fulcro, enquanto as regiões sob maior tensão de compressão são os contatos oclusais, o fulcro e o ápice da raiz. Como o esmalte e a dentina possuem alta resistência àcompressão, pouca ou nenhuma ruptura de estrutura cristalina ocorre com tensão de compressão. Entretanto, a habilidade das estruturas dentárias para suportar as tensões de tração é limitada, causando a ruptura das ligações químicas entre os cristais de hidroxiapatita. À medida que as ligações entre os cristais são quebradas, pequenas moléculas de água podem penetrar nos espaços existentes e impedir o restabelecimento das ligações químicas entre a estrutura cristalina. Caso as tensões de tração permaneçam durante a mastigação ou bruxismo, a estrutura dentária torna-se mais susceptível àdissolução química e fratura por forças físicas como fricção, por escovação, compressão e cisalhamento. Dessa forma, as lesões resultantes das tensões de tração deveriam possuir características peculiares, como estar próximo ou no fulcro do dente, possuir morfologia típica de cunha, representativa do volume de maior concentração de tensões nessa região. Fatores locais poderiam modificar a forma da lesão, mas o padrão universal deveria ser forma de cunha com ângulos nítidos. A direção das forças laterais geradas pela tensão de tração determina a localização da lesão. O tamanho da lesão está diretamente relacionado com a magnitude e frequência da aplicação das forças que gera a tensão de tração na região cervical. Os autores concluíram que embora as tensões de tração tenham sido propostas como o fator desencadeador na etiologia das lesões cervicais, múltiplos fatores, como a abrasão por escovação, ácidos presentes no fluido oral, presença de fluoretos no dente e nos fluidos orais, a presença do dente adjacente que influi na flexão do dente sob tensão de tração e o alinhamento e a anatomia do dente afetam o desenvolvimento do processo.

\section{Em 1988, BEVENIUS; L'ESTRANGE; ANGAR-}

MANSSON ${ }^{11}$ elaboraram um guia prático para uso dos clínicos para ajudar no diagnóstico diferencial entre lesões de erosão, abrasão e atrição. As lesões cervicais não cariosas, muitas vezes, têm sido restauradas com os materiais restauradores 
estéticos sem um diagnóstico diferencial prévio e sem a identificação dos fatores etiológicos. De acordo com Pindborg, as lesões erosivas são resultantes da perda de estrutura dentária por um processo químico que não envolve bactéria. As superfícies das lesões são lisas e polidas com margens bem definidas, e caracteristicamente livres de placa macroscópica. Quando a superfície dentinária está exposta, ocorre exacerbação da sensibilidade. Os autores sugeriram o emprego de alguns passos para o estabelecimento do diagnóstico diferencial: examinar as lesões sob boa iluminação, limpar e secar a região, de preferência com papel absorvente, e anotar a localização, a aparência e a severidade da lesão; fotografias; registro de modelos; testes salivares, história médica com relatos de medicações atuais e dieta. Essas informações são úteis para o estabelecimento de um diagnóstico preliminar e avaliação do principal fator etiológico.

GRIPPO ${ }^{48}$, em 1991, descreveu abfração como a junção de duas palavras latinas, $a b$ significa para fora e fraction ruptura, e, designa a perda patológica de estrutura dentária originada por forças biomecânicas por causa da flexão dentária e conseqüente fadiga do esmalte e da dentina em um ponto distante da aplicação das forças. $O$ efeito dessas forças depende de sua direção, magnitude, frequência, duração e localização, quando os dentes entram em contato durante a mastigação e parafunção, causando lesões no esmalte e na dentina. No esmalte, as lesões podem ser desde pequenas trincas, acentuadas com luz transmitida ou estrias horizontais, chamados planos de deslocamento molecular ou linhas de Luder, ou então possuir forma de pires, semilunar ou, ainda, invaginação nas pontas das cúspides. Na dentina, as lesões podem se apresentar como defeitos angulares profundos na margem gengival da superfície vestibular, possui forma circunferencial, localização subgengival, lingual ou interproximal, simples ou múltiplas, alternadas, com ângulo de $45^{\circ}$ e, ainda, nas margens das coroas e restaurações. Portanto, o sentido do termo abfração, dado pelo autor, não se limita a lesões em forma de cunha, mas a todas as lesões advindas de sobrecarga oclusal. 
Em 1991, HOOD ${ }^{57}$, relatou a necessidade do conhecimento dos aspectos relacionados à biomecânica de dentes hígidos, preparados e restaurados para se obter uma resposta clínica satisfatória. $\mathrm{O}$ autor constatou que forças aplicadas na superfície oclusal do dente induzem estresses em restaurações localizadas em um ponto distante àaplicação da força, resultando numa diminuição das dimensões cervico-oclusais do preparo, e que, a magnitude da deformação está relacionada \&̀ dimensões da quantidade de tecido dentário perdido, sendo esses efeitos são mais característicos nos dentes molares e pré-molares quando comparados aos incisivos.

GALLIEN; KAPLAN; OWENS ${ }^{44}$, em 1994, relataram um aumento na prevalência e na conscientização a respeito das lesões cervicais não cariosas, devido ao envelhecimento da população e do aumento da preocupação estética dos pacientes. Afirmaram que a comunidade odontológica não está completamente esclarecida a cerca dos fatores etiológicos e da classificação das lesões cervicais não cariosas. Embora os termos abrasão, erosão, atrição e abfração tenham diferentes significados, são utilizados pelos dentistas de modo permutável no diagnóstico das lesões cervicais não cariosas. Conforme descrito por vários autores, lesões de abrasão são produzidas pela fricção de materiais exógenos sobre as superfícies dos dentes, causando destruição da superfície dentária. Esses materiais incluem cerdas de escovas de dente, dentifrício e alimentos. As lesões resultantes são côncavas e apresentam uma textura de superfície lisa, sendo usualmente encontradas nas faces vestibulares dos dentes. A atrição é o desgaste resultante do contato dente-a-dente durante movimentos funcionais ou parafuncionais. Áreas de atrição são geralmente superfícies planas bem definidas, com bordas bem delimitadas, produzindo facetas de desgaste na superfície incisal ou oclusal do dente antagônico. As lesões de erosão se referem àperda de estrutura dentária devido àação de agentes químicos de origem exógena, como bebidas ácidas e carbonatadas e sucos de frutas cítricas, e endógena através da regurgitação de ácidos gástricos. Essas lesões ocorrem tanto nas superfícies vestibulares quanto nas linguais. $O$ termo abfração é oriundo do processo resultante da ação de estresse tensional, causado por forças laterais ou excêntricas sobre o 
dente, determinando o aparecimento da lesão. Essas peculiares lesões em $V$ ou em forma de cunha são localizadas em áreas de má-oclusão e em áreas onde abrasão por escovação são improváveis, como por exemplo, sob a margem gengival livre ou superfícies proximais. Outra particularidade desse fenômeno é a ocorrência de lesões em apenas um único dente do arco, enquanto os adjacentes permanecem hígidos. O tratamento consiste da restauração com resina composta ou cimento de ionômero de vidro e/ou a remoção dos fatores causais. Caso a estética não esteja comprometida e a perda de estrutura dentária não comprometa a resistência do dente, o tratamento pode-se basear na observação dessas lesões. Os autores concluem enfatizando a necessidade de um acurado exame clínico para determinar a etiologia e o correto diagnóstico de lesões cervicais.

LAMBERT; LINDENMUTH ${ }^{65}$, em 1994, analisando a dificuldade de determinar os fatores etiológicos das lesões cervicais não cariosas, observaram que durante anos essas lesões tiveram sua etiologia marcada por hábitos incorretos de escovação, entretanto muitos clínicos observaram que as lesões frequentemente ocorrem num determinado dente sem o acometimento dos adjacentes. Os autores apresentam vários trabalhos que corroboram com a teoria do estresse oclusal como fator etiológico primário para a formação das lesões cervicais não cariosas. O novo termo abfração caracteriza a lesão cervical de forma irregular, esta forma correlaciona-se com as áreas de compressão e tensão exercidas pelas forças oclusais. Os prismas de esmalte são resistentes em compressão e frágeis em tração, dessa forma, a lesão resultante é menor em áreas de compressão e maior na área de tração. Portanto, as forças oclusais devem ser consideradas como um fator etiológico na formação das lesões cervicais, bem como na falha de restaurações cervicais por meio de um diagnóstico acurado.

YAP; NEO $^{128}$, em 1995, analisaram que os termos lesões de erosão/abrasão, abrasão cervical, defeitos em forma de cunha, cavidades de abrasão, entalhes cervicais e lesões cervicais idiopáticas referem-se àmesma entidade clínica, caracterizada pela perda do contorno vestibular na junção cementoesmalte. Os autores postularam a padronização da terminologia como lesões 
cervicais não cariosas, e sugeriram um guia para o diagnóstico, a prevenção e o monitoramento dessas lesões. Estudos de prevalência das lesões cervicais mostram que a taxa de manifestação dessa doença em adultos jovens é menor que $20 \%$, e maior que $30 \%$ em idosos, sugerindo um aumento da prevalência com a idade. O sucesso no tratamento das lesões cervicais consiste num correto diagnóstico. Os autores concluem enfatizando o papel importante do diagnóstico na prevenção de alterações patológicas derivadas das lesões cervicais e a importância do acompanhamento do desgaste dentário como meio de verificar a efetividade de medidas preventivas.

BADER et al. ${ }^{7}$, em 1996, examinaram os fatores associados àetiologia das lesões cervicais não cariosas. Os pacientes examinados estavam expostos à três maiores causas do aparecimento das lesões, que são: abrasão, erosão e flexão do dente, através de exame clínico, anamnese e questionário de dieta. Os resultados sugerem que as lesões cervicais não cariosas têm etiologia multifatorial, e que o mecanismo de causa múltipla está envolvido no surgimento e na progressão de uma lesão individual.

LEE; EAKLE $^{67}$, em 1996, revisaram o conceito de flexão dentária após dez anos da hipótese na qual as tensões de tração geradas oclusalmente poderiam induzir a formação de lesões cervicais não cariosas. A morfologia das lesões em forma de cunha e sua frequente localização subgengival não poderia ser explicada pelas teorias de abrasão por escovação ou erosão ácida, e o trauma oclusal isoladamente não oferece uma adequada explicação, pois existe uma ampla evidência de que muitos dentes exibem sinais de oclusão traumática sem apresentar lesões cervicais. A introdução do conceito de estresse oclusal e seu componente de tração gerado na região cervical tiveram boa aceitação na etiologia primária e desenvolvimento dessas lesões porque pôde explicar sua morfologia e localização, estando de acordo com os princípios mecânicos aplicados à estruturas dentárias e materiais restauradores, oferecendo uma base racional para o tratamento adequado. De acordo com os autores, o ponto principal para o diagnóstico diferencial de lesões cervicais provocadas por estresse oclusal é a 
presença de forças laterais durante a mastigação ou movimentos parafuncionais. Outros aspectos que contribuem para o diagnóstico são a presença de faceta de desgaste, lesões em forma de cunha, localização subgengival, a perda da guia anterior e a orientação do longo eixo dos dentes em relação \&̀ forças oclusais. Destacou-se que embora as tensões de tração sejam apontadas como um fator etiológico primário, a etiologia multifatorial das lesões cervicais não cariosas deve sempre ser considerada. Os autores concluíram que a estrutura dentária não é uma entidade estática e está sujeita a deformação sob cargas oclusais, e que uma adesão àestrutura dentária deve ser acompanhada de um certo grau de flexibilidade do material restaurador adesivo para acomodar a deformação sob estresse.

HANAOKA et al. ${ }^{50}$, em 1998, categorizaram a etiologia das lesões cervicais não cariosas, identificaram as relações entre os fatores biomecânicos e a formação de lesões cervicais e investigaram o método mais efetivo para a restauração desses tipos de lesões. A etiologia das lesões cervicais não cariosas é categorizada da seguinte forma: abrasão (desgaste friccional mecânico), erosão (dissolução química), abfração (perda induzida por estresse oclusal). As lesões cervicais não cariosas podem ser causadas pela interação multifatorial desses mecanismos, mas não somente por um único mecanismo. A teoria da flexão dentária proposta por Lee e Eakle é um mecanismo satisfatório para explicar a formação dos defeitos cervicais no esmalte próximo àjunção amelocementária, entretanto, não existem evidências da formação de defeitos em dentina e cemento. Dessa forma, os autores propuseram um ensaio biomecânico para dar suporte à teoria da flexão do dente. Eles concluíram que as microfendas na dentina e no cemento, oriundas de acúmulo de estresse podem agir como fator contribuinte inicial na formação dos defeitos cervicais. Em relação ao tratamento a ser instituído, os autores afirmaram que a determinação dos fatores etiológicos que estão atuando em cada paciente e a eliminação desses fatores é essencial para se obter um resultado satisfatório do tratamento. As lesões cervicais devem ser restauradas para prevenir a perda contínua de estrutura dentária e para o reforço do dente, quando estiver com sensibilidade intolerável, comprometimento estético e para manutenção da higiene oral e prevenção de cárie. 
Com o objetivo de verificar a relação existente entre o estresse oclusal, a saúde periodontal e hábitos alimentares com o aparecimento de lesões cervicais não cariosas, MAYHEW; JESSEE; MARTIN ${ }^{76}$, em 1998, delinearam um projeto para contribuir no estudo da etiopatogenia desses tipos de lesões. Um total de 178 lesões cervicais foi examinado em 43 pacientes, os quais foram questionados acerca dos hábitos alimentares, e passaram por criteriosos exames oclusal e periodontal. A avaliação da dieta consistiu no relato da ingestão de comidas e/ou bebidas ácidas nas últimas 24 horas, a avaliação periodontal, consistiu da medição da perda de inserção com sonda periodontal, presença de mobilidade dentária e verificação da perda óssea pelo exame radiográfico. O exame oclusal avaliou a forma e a orientação das lesões, a presença e a localização de facetas de desgaste e, sintomas e características da oclusão cêntrica e excêntrica. Os resultados indicaram que 95\% das lesões examinadas exibiram facetas de desgaste, indicando uma forte correlação entre facetas e a presença de lesões cervicais não cariosas; $98,3 \%$ dos dentes examinados apresentaram mobilidade menor ou igual a 1 , e não houve associação entre a presença de faceta e mobilidade, como também não houve correlação entre a presença de lesões e a dieta. Fatores como a idade e oclusão traumática em pacientes com desoclusão em grupo podem estar relacionados com a etiologia das lesões cervicais não cariosas. Entretanto, os autores concluíram que estudos longitudinais devem ser conduzidos para confirmar a etiologia das lesões cervicais e estabelecer o tratamento mais apropriado.

MILOSEVIC et al. $^{78}$, em 1998, destacou a natureza multifatorial da etiologia das lesões cervicais não cariosas e as dificuldades encontradas para se chegar a um correto diagnóstico. A erosão pode ter origem extrínseca devido aos ácidos provenientes de alimentos, bebidas e processos industriais e intrínsecas devido a doenças de refluxo gastro-esofágico e desordens alimentares como anorexia nervosa e bulimia. A atrição ou desgaste atricional resulta do contato dente a dente o qual ocorre no ponto de contatos proximais e superfície oclusal/incisal durante a função normal, ou nas pontas das cúspides durante apertamento ou bruxismo. A abrasão refere-se ao desgaste da estrutura 
dentária por processos mecânicos, como na escovação vigorosa com dentifrícios abrasivos. A abfração resulta da aplicação de cargas oclusais excêntricas, levando à flexão do dente e ao desenvolvimento de tensões de tração e compressão na região cervical do dente. Os autores concluíram ratificando que as orientações preventivas dos pacientes em relação ao desgaste dentário e hábitos alimentares devem ser implementadas pelos profissionais.

NEVES; DISCACCIATI ${ }^{82}$, em 1999, realizaram uma revisão de literatura sobre a etiologia, diagnóstico e tratamento das lesões de abfração. Como descrito por diversos autores, lesões de abrasão são decorrentes da fricção de materiais exógenos sobre a superfície dos dentes. Ocorre tanto nas faces oclusais/incisais, como nas vestibulares e proximais, sendo que nessas duas geralmente envolvendo superfícies radiculares expostas. Hábitos orais como segurar pregos, grampos e tachas, uso de cachimbos e procedimentos vigorosos de higiene oral são os maiores causadores de abrasão dental. A atrição é definida como o desgaste resultante do contato dente a dente através de movimentos funcionais ou parafuncionais incluindo mastigação e bruxismo. Ela se apresenta como facetas de desgaste bem definidas, planas com margens bem circunscritas. Pode ocorrer nas faces oclusais, incisais e proximais dos dentes. Esse fenômeno é mais fisiológico que patológico, estando associado ao processo de envelhecimento. Já a erosão, seria a perda de substância dentária devido a um processo químico não envolvendo bactérias. É denominada de extrínseca aquela causada por ácidos da dieta, medicamentos, água de piscina e do ar no ambiente de trabalho, e de intrínseca ou perimólise, aquela causada por regurgitação do suco gástrico, muito comum em pacientes portadores de hérnia de hiato. No entanto, um tipo específico de perda de estrutura dentária não se relaciona a essas três definições. Trata-se de uma perda geralmente em forma de cunha, mais comum em superfícies cervicais vestibulares, podendo ocorrer também em proximais, linguais de dentes que normalmente apresentam bom suporte periodontal. Tais lesões podem afetar dentes subseqüentes de um hemiarco ou um único elemento dentário, permanecendo seus vizinhos intactos. Podem também ocorrer sob as margens de coroas totais e restaurações cervicais, e sob a gengiva marginal livre. Todos esses achados vieram 
descartar a possibilidade de serem os procedimentos de higiene oral o fator etiológico primário para tais lesões. Diversas teorias relativas àetiologia desse tipo de lesão têm sido propostas, incluindo a hiperatividade dos tecidos moles circundantes, aumento do fluxo do fluido cervicular gengival devido a trauma oclusal e flexão dentária causada por forças oclusais. Esta última, proposta por Lee e Eakle, parece ser a mais realista. Em relação ao tratamento, existe hoje um consenso entre os autores, afirmando que deve ser instituído levando-se em consideração o fator causal, uma vez que, caso seja feita apenas a restauração do defeito, a lesão pode reaparecer em um nível mais apical ou mesmo a restauração se deslocar. Os autores concluíram que o diagnóstico diferencial deve ser feito, levando-se em consideração todos os fatores causais que podem estar atuando naquele determinado momento. O tratamento deve ser baseado nesse diagnóstico, eliminando os fatores causais e restaurando-se o defeito.

OSBORNE-SMITH; BURKE; WILSON ${ }^{83}$, em 1999, num trabalho de revisão, afirmaram que as lesões cervicais não cariosas podem ser definidas como a perda de estrutura dentária na região cervical do dente através de um processo que não envolve bactéria. A abrasão e a erosão têm sido amplamente reportadas como os fatores causais das lesões cervicais não cariosas. Entretanto, mais recentemente a flexão do dente tem sido relacionada ao aparecimento dessas lesões, proporcionando um renovado interesse na patogênese da perda de estrutura na região cervical dos dentes. Na verdade, a etiologia das lesões cervicais não cariosas é complexa, com erosão, abrasão e a flexão do dente apresentando diferentes contribuições na formação e no desenvolvimento das lesões. Os autores fazem uma descrição detalhada de cada um dos diferentes tipos de lesões objetivando determinar o fator causal primário. $O$ tratamento deve ser baseado no conhecimento dos fatores etiológicos e terapias paliativas devem ser preferidas.

TELLES; PEGORARO; PEREIRA ${ }^{107}$, em 2000, publicaram um estudo a respeito da prevalência das lesões cervicais não cariosas em acadêmicos de Odontologia e sua relação com aspectos oclusais, foi constatado que das quarenta e oito pessoas, com idades entre 16 e 24 anos, 50\% apresentaram 
pelo menos um dente com lesão cervical não cariosa, denotando alta precocidade no aparecimento dessas lesões. As lesões ocorreram predominantemente na face vestibular, sendo que os dentes mais atingidos foram os primeiros molares superiores com $21,3 \%$, seguidos pelos primeiros pré-molares superiores, com 16,9\%. A idade revelou ser um fator significativo na ocorrência das lesões, uma vez que as lesões cervicais não cariosas apresentaram-se nos indivíduos de faixa etária mais elevada. A análise dos modelos de gesso dos dentes que apresentaram lesões revelou que $78,5 \%$ apresentavam facetas de desgastes indicativas de hábitos parafuncionais. No grupo com lesão, a média foi de quinze dentes com facetas de desgaste por indivíduo, enquanto que no grupo sem lesão a média foi de 10,8, sugerindo que o estresse oclusal tem alguma influência no desenvolvimento das lesões.

ALMEIDA $^{3}$, em 2001, avaliou em microscopia óptica de luz convencional e polarizada e microscopia eletrônica de varredura, as eventuais alterações na estrutura dos tecidos dentários mineralizados na região cervical de pré-molares humanos e correlacioná-las com o desenvolvimento de tensões durante o ato mastigatório, tendo-se como parâmetro de comparação a idade dos pacientes e a prevalência de facetas de desgaste oclusal, com vistas àetiopatogenia das lesões cervicais não cariosas. Para a análise em microscopia óptica foram selecionados 160 pré-molares, estabelecidos de acordo com os seguintes critérios: Grupo I (controle) - 15 dentes fora de oclusão; grupo II (experimental) - 80 dentes de pacientes entre 10 e 19 anos; grupo III (experimental) - 50 dentes entre 20 e 29 anos e grupo IV - 15 dentes apresentando lesões cervicais não cariosas. A análise dos resultados permitiu concluir que: as alterações morfológicas dos tecidos dentários mineralizados encontradas na região cervical dos pré-molares foram positivamente associadas com a prevalência de facetas de desgaste oclusal nas duas faixas etárias estudadas; a elevada variabilidade morfológica das lesões cervicais reflete mecanismos intrínsecos a sua etiologia multifatorial; a prevalência de facetas de desgaste oclusal aumentou com a idade; as tensões originárias da mastigação influenciam na prevalência das alterações na micromorfologia dos tecidos dentários mineralizados, sugerindo que podem atuar como fator dominante 
ou co-fator na etiopatogenia das lesões cervicais não cariosas; o fator determinante da ocorrência de alterações nos tecidos dentários mineralizados na região cervical é a presença de esforços oclusais funcionais ou da parafunção, representados pelo aumento da prevalência de facetas de desgaste oclusal com a idade dos pacientes nas duas faixas etárias estudadas.

LYONS $^{71}$, em 2001, abordou numa revisão de literatura a etiologia das lesões de abfração, considerando-a complexa. Há muitas evidências de que 0 início dessas lesões ocorre como resultado do estresse gerado oclusalmente, resultando em flexão do dente. A influência da microflora oral e a abrasão causada pela escovação combinada com a dinâmica atividade inter-oclusal são os responsáveis pelo desenvolvimento das lesões de abfração. Várias teorias têm sido propostas e numerosas pesquisas e estudos têm sido conduzidos, mas o fator causal primário ainda está para ser definitivamente determinado. A constante deformação causada pelo estresse oclusal induz a alternadas expansão e compressão da estrutura dentária na região cervical do dente e, como resultado, ocorre a fratura da pequena espessura de esmalte friável dessa região. Uma vez iniciado o processo de perda de estrutura dentária e coadjuvado com os fatores de erosão, abrasão e oclusão a perda de estrutura é acentuada, denotando a atividade multifatorial da etiologia das lesões cervicais não cariosas. Esse trabalho de revisão conclui que a carga oclusal é o fator inicial para o desenvolvimento das lesões de abfração.

\subsection{Avaliações Clínicas de Restaurações de Lesões Cervicais não Cariosas}

BRANDAU; ZIEMIECKI; CHARBENEAU ${ }^{18}$, em 1984, realizaram um estudo de acompanhamento clínico por 4 anos e 6 meses de restauração de lesões cervicais com cimento de ionômero de vidro. Eles afirmaram que a adesão do ionômero àdentina representa uma grande vantagem para a restauração de lesões com profundidades tão reduzidas quanto $1 \mathrm{~mm}$, evitando dessa forma o deslocamento da restauração, contribuindo para a higiene do paciente e eliminando o desconforto de estímulos térmicos e tácteis através da 
cobertura da dentina exposta. Esse estudo foi desenvolvido para avaliar as características clínicas e a utilização do cimento de ionômero de vidro em restaurações de defeitos cervicais sem a execução de preparo cavitário para auxiliar na retenção. Um total de 148 restaurações foi confeccionado em 32 pacientes com pelo menos uma lesão cervical com profundidade maior que $1 \mathrm{~mm}$ na região central. Antes da execução das restaurações, analisou-se a relação entre as paredes cervical e incisal com o plano sagital, classificando-as de acordo com a angulação e posterior verificação da relação existente entre a angulação e a retenção. Os procedimentos restauradores foram realizados de acordo com as orientações do fabricante e as restaurações foram avaliadas pelos critérios desenvolvidos por Cvar e Ryge, analisando-se a cor, descoloração marginal, forma anatômica, adaptação marginal, cárie, retenção e textura superficial (Método de Chandler). As avaliações foram conduzidas por dois examinadores independentes que chegavam a um consenso quando havia divergências. Os autores concluíram que o cimento de ionômero de vidro usado para restauração de defeitos cervicais apresentou uma adequada união com a estrutura dentária mesmo sem qualquer forma de retenção mecânica, pois $75 \%$ das restaurações estiveram presentes ao final de 54 meses de avaliação. A perda das restaurações (25\%) não parece estar associada com a angulação e o tipo de defeito cervical e sim com a pequena profundidade da lesão nas extremidades mesial e distal do defeito cervical. Em relação àforma anatômica, $80 \%$ das restaurações apresentaram uma continuidade com a estrutura dentária, sendo que $7 \%$ apresentaram sobcontorno e $13 \%$ perda de material com exposição dentinária. A descoloração marginal foi evidente em apenas $9 \%$ das restaurações. Não houve evidências de cárie e a sensibilidade diminuiu ou foi eliminada completamente após a restauração das lesões e permaneceu inalterada em todo o período de avaliação.

VANHERLE et al. ${ }^{122}$, em 1986, idealizaram um estudo clínico para verificar a performance do sistema restaurador adesivo Scothbond/Silux na restauração por períodos prolongados sem a preparação cavitária. Uma equipe de 5 dentistas realizou 276 restaurações divididas em três categorias: Grupo A limpeza da superfície dentária com pedra-pomes e água e peróxido de hidrogênio 
com posterior aplicação de duas camadas de Scothbond na dentina seguida de resina composta. As restaurações foram polidas de acordo com os limites da lesão; Grupo B - a limpeza da lesão foi feita da mesma forma que no Grupo A, sendo acrescido de condicionamento ácido do esmalte. A aplicação do adesivo foi feita no esmalte e na dentina e o acabamento foi realizado com sobrecontorno na margem incisal; no Grupo C - fez-se o mesmo tratamento que o grupo B, só que se aplicou o adesivo de esmalte e não o Scothbond, e a restauração também foi realizada com sobrecontorno. As restaurações foram avaliadas inicialmente (baseline) com relação àaparência estética e adaptação marginal. A outra avaliação foi conduzida quando a média das restaurações estava com 6 meses e o índice de retorno foi de $71 \%$. A avaliação da adaptação marginal foi realizada com uma sonda e espelho clínico e os escores foram divididos em dois grupos, o primeiro de restaurações clinicamente aceitáveis sem falha marginal ou com apenas um defeito numa margem, e o segundo com restaurações clinicamente inaceitáveis com vários defeitos ou perda parcial e perda total da restauração. Ao final de 6 meses, $85,2 \%$ das restaurações estavam clinicamente aceitáveis e $14,8 \%$ inaceitáveis com relação àadaptação marginal. Comparando os tratamentos realizados, os Grupos B e C obtiveram resultados similares, enquanto o Grupo $A$ obteve os piores resultados com $15 \%$ das restaurações perdidas e 2,3\% para os demais grupos. Os autores concluíram que a técnica $A$ é insatisfatória devido ao grande número de falhas em retenção nos primeiros 6 meses de avaliação. A técnica $C$ foi mais biocompatível não apresentando necrose pulpar, entretanto ocorreu o aparecimento de lesões cariosas em $6 \%$ dos casos.

\section{ZIEMIECKI; DENNISON; CHARBENEAU ${ }^{133}$, em 1987,} avaliaram clinicamente um sistema adesivo de presa química, o Scothbond, na restauração de lesões de erosão/abrasão. O estudo foi delineado com o objetivo de avaliar a retenção de lesões cervicais sem a confecção de preparo cavitário, apenas com o emprego do sistema adesivo; avaliar o desempenho de cada restauração por exame visual, nos critérios de cor, descoloração marginal, adaptação marginal, forma anatômica e cárie secundária e, finalmente analisar a sensibilidade pré e pósoperatória. Um total de 37 pacientes recebeu 171 restaurações, sendo divididos em 
três grupos. O sistema adesivo Scothbond foi aplicado em todos os dentes, variando-se em cada grupo o tipo de resina composta ou a técnica de preparo. No Grupo I ( $n=54)$ empregou-se uma resina quimicamente ativada, Silar, 3M; no Grupo II ( $n=66)$ utilizou-se uma resina fotoativada, Silux, 3M; e no Grupo III $(n=51)$ empregou-se a mesma resina do grupo anterior, mas os dentes receberam um tratamento do ângulo cavo-superficial na forma de bisel e condicionamento do esmalte. As restaurações foram avaliadas nos períodos inicial, seis meses e doze meses por dois examinadores. Os resultados indicaram um acentuado decréscimo da sensibilidade no período de um ano. No que diz respeito à retenção, as restaurações dos Grupos I e II tiveram um desempenho semelhante aos seis meses (87\% e $86,4 \%$ respectivamente), entretanto, no período de um ano a diferença entre os grupos passou para 8\%, 72\% para Silar e 80\% para Silux. Quando o esmalte foi biselado e condicionado, o índice de retenção foi de $100 \%$ e $90 \%$ aos seis meses e um ano, respectivamente. $O$ índice de retenção foi menor na mandíbula que na maxila, indicando uma maior dificuldade de realização do isolamento do campo operatório. As características das lesões, nas restaurações que falharam são as seguintes: a maior parte das lesões era de forma circular, com ângulo maior que $135^{\circ}$ e com dimensões inciso-cervicais menores que $2 \mathrm{~mm}$ e profundidade de $1 \mathrm{~mm}$. Os autores concluíram que o biselamento e o condicionamento ácido do esmalte proporcionaram maior retenção quando comparados com apenas a aplicação do sistema adesivo.

HEYMANN et al. ${ }^{54}$, em 1988, delinearam um estudo para avaliar a performance clínica de dois sistemas restauradores adesivos e combinação de diferentes técnicas de aplicação dos sistemas adesivos para restauração de 178 lesões cervicais de Classe V. A superfície dentinária foi abrasionada com pontas diamantadas e os dentes passaram por uma profilaxia com pasta de pedra-pomes e água. O preparo restringiu-se ao biselamento do ângulo cavo-superficial incisal/oclusal sem a execução de retenções mecânicas adicionais. A superfície adamantina foi condicionada com ácido fosfórico a 37\% na forma de gel e seguiu-se a aplicação do sistema adesivo de acordo com a técnica a ser empregada e posterior restauração. Todas as restaurações foram avaliadas por dois 
examinadores pelo método direto nos períodos inicial, dois, seis e doze meses usando os critérios do USPHS, retenção e sensibilidade pós-operatória. Foi anotado na ficha clínica sinais de bruxismo, apertamento e presença de facetas de desgaste que evidenciasse estresse oclusal excessivo para correlacionar com falhas na retenção. O índice de retorno após um ano foi de $94 \%$. Os índices de retenção nos períodos de avaliação de 2 meses, 6 meses e 1 ano foram respectivamente 91,6/ 87,6/ 82,6. Não houve diferença entre os índices de retenção e as variáveis empregadas. Entretanto, o maior número de falhas ocorreu com a utilização da resina composta Prisma-Fil com o adesivo Prisma Universal Bond aplicado numa única camada. O menor número de falhas ocorreu com a utilização da resina Prisma Micro-Fine e o prisma Universal Bond aplicado em duas camadas. A resina de macropartícula apresentou maior número de falhas (17) que a microparticulada (10), embora, não tenha havido diferença estatisticamente significante. Em relação aos fatores de oclusão associados, dos treze pacientes que apresentaram falhas, doze tinham algum tipo de fator interferente (facetas, bruxismo e/ou apertamento), tendo apresentado associação estatisticamente significante. A associação também foi evidente no fator idade, onde os pacientes mais velhos apresentaram maiores falhas. No que diz respeito àlocalização das restaurações, não houve diferença em relação ao tipo de dente, mas houve diferença em relação ao arco, havendo maior número de falhas na região da mandíbula. Os critérios do USPHS apresentaram pequena variação na cor, descoloração marginal e integridade marginal, entretanto não houve diferença estatisticamente significante entre as variáveis testadas. Os autores concluíram que embora não tenha havido diferença estatisticamente significante para os critérios e combinações avaliadas, os fatores de oclusão traumática e idade do paciente ou combinação de ambos parecem estar envolvidos no índice de falhas das restaurações.

Em um trabalho de revisão sobre os materiais empregados para restauração de lesões cervicais, BRACKETT; ROBINSON ${ }^{13}$, em 1990, afirmaram que o uso da resina composta e do cimento de ionômero de vidro apresenta grande vantagem estética em relação ষ̀ restaurações metálicas. O aspecto da união àestrutura dentária desenvolvido por esses materiais reduz ou 
elimina a necessidade de preparação cavitária. Os materiais àbase de resina composta apresentam um excelente resultado estético em áreas cervicais por apresentarem uma aceitável reprodução da cor natural dos dentes. Para o sucesso clínico com o uso da resina composta em lesões cervicais as margens em esmalte devem ser biseladas e condicionadas para melhorar a retenção. Estudos clínicos advertem que o prognóstico para retenção em lesões cervicais sem preparo cavitário é crítico na presença de estresse oclusal, com o aumento da idade do paciente e quando as lesões são de pequena espessura. A adesividade do cimento de ionômero de vidro àestrutura dentária torna -o como o material de eleição para restauração de lesões cervicais não retentivas. Estudos têm demonstrado um índice de retenção para o cimento de ionômero de vidro maior que $90 \%$ após três anos. Os autores concluíram que o cimento de ionômero de vidro apresenta o menor índice de cárie secundária e melhores resultados na retenção de restaurações de lesões cervicais sem a execução de preparo cavitário. Reforça que o uso de materiais combinados (cimento de ionômero de vidro e resina composta) tem apresentado um prognóstico satisfatório na restauração de lesões cervicais com resina composta, mas acrescenta que independente da técnica empregada para obter-se um bom desempenho das restaurações é necessário seguir as especificações do fabricante e um adequado isolamento do campo operatório.

BAYNE et al. ${ }^{9}$, em 1991, categorizaram as variáveis que devem ser controladas no delineamento de um estudo clínico bem conduzido e as dividiram em cinco grupos: 1- preparo do dente, 2- operador, 3- material, 4localização intra-oral e 5- variáveis do paciente. Discutiu-se a influência desses fatores no estudo de sistemas adesivos na solução de casos de lesões de Classe V. Nesse estudo testou-se a retenção de dois sistemas adesivos combinados com três resinas compostas e três técnicas de aplicação do adesivo distintas em 178 restaurações. As restaurações foram avaliadas nos períodos inicial, 2 e 6 meses, 1, 2 e 3 anos após a colocação usando os critérios do USPHS, sensibilidade e retenção. Os resultados da avaliação do USPHS ficaram praticamente inalterados. Toda sensibilidade foi resolvida pelo tratamento. O resultado mais interessante foi a correlação existente entre as falhas de retenção em pacientes mais velhos. Os 
pacientes de 21-40, 41-60 e 61-80 tiveram perdas na retenção de respectivamente, $31 \%, 62 \%$ e $75 \%$. As condições intra-orais representam um fator muito crítico para o delineamento de estudos clínicos e devem ser minuciosamente observadas. $O$ formato da lesão, superfície disponível para adesão, extensão do esmalte, tipo de dentina e a dinâmica do substrato devem ser considerados.

HANSEN $^{51}$, em 1991, avaliou o índice de retenção cumulativa após cinco anos de restaurações de lesões de erosão restauradas com resina composta de micropartícula. Um total de 105 restaurações foi executado com a resina Silux, sendo 75 tratadas com Gluma e 30 com Scothbond-1. O preparo do dente restringiu-se àmodificação da superfície dentinária pelo emprego de pontas diamantada e o biselamento do ângulo cavo-superficial. Não foi confeccionado retenções mecânicas adicionais e utilizou-se dique de borracha para o isolamento. $O$ índice de retenção após cinco anos para os sistemas Gluma/Scothbond-1 foi respectivamente de $90 \%$ e $47 \%$. O índice de retenção para ambos os sistemas foi significantemente maior na maxila que na mandíbula.

van MEERBEEK et al. ${ }^{117}$, em 1993, avaliou por um período de dois anos a eficácia de dois sistemas adesivos, o Clearfil New Bond e o Scothbond 2. Os critérios avaliados foram índice de retenção e adaptação marginal em 306 lesões cervicais de Classe V. As lesões apresentavam etiologias diversas e os dentes foram divididos em dois grupos experimentais, o Grupo A, onde não foi realizado qualquer tipo de preparo ou condicionamento ácido $\mathrm{e}$ as margens apresentavam uma relação de 90ำ com a superfície externa do dente, e o Grupo B, em que se realizou o biselamento das margens de esmalte e posterior condicionamento. O adesivo Clearfil foi aplicado em 189 lesões (Grupo A=41, Grupo $B=148$ ) e o adesivo Scothbond 2 em 117 lesões, sendo 50 no Grupo A e 67 no grupo B. A eficácia clínica foi determinada pela porcentagem de restaurações perdidas após o período de seis meses e dois anos. Os resultados demonstraram que para o sistema Clearfil, $21 \%$ das restaurações do Grupo A falharam ao final de dois anos, ao passo que somente $1 \%$ das restaurações do Grupo B apresentou falha. Para o sistema Scothbond 2, 13\% das restaurações do Grupo A foram 
perdidas e todas as restaurações do Grupo B estavam retidas. Apesar disso, a adaptação marginal das restaurações cervicais restauradas com Clearfil/Clearfil Ray revelaram menores defeitos comparados com o Scothbond/Silux Plus.

HEYMANN; BAYNE ${ }^{56}$, em 1993, revisaram os fatores envolvidos para o sucesso da adesão dentinária. Muitos estudos laboratoriais têm demonstrado uma grande variabilidade de resultados de resistência adesiva, dessa forma, os valores clínicos desses estudos estão sempre sob suspeita. Atualmente, os novos sistemas adesivos reportam valores de resistência adesiva mais elevados, e para confirmação desses valores, inúmeras pesquisas clínicas estão sendo conduzidas. No entanto, a grande maioria dos estudos relata somente fatores referentes aos materiais e comparação entre produtos. Embora as diferenças dos materiais afetem a adesão, existem outras variáveis clínicas importantes que devem ser consideradas. Os autores relataram de maneira direta os fatores da adesão dentinária, ressaltando a importância de cada um e sua interferência no processo adesivo. Os fatores considerados foram: dentina, dente, paciente e material.

IANZANO; GWINNETT ${ }^{61}$, em 1993, avaliaram a performance clínica do sistema adesivo All Bond 2 e da resina composta Bis-Fil M empregando a técnica do condicionamento ácido total. Trinta e seis pacientes participaram do estudo, com um número igual de homens e mulheres, e idade média de 61 anos. Um total de 78 restaurações foi confeccionado, sendo que um máximo de três por paciente. As restaurações foram confeccionadas por um único operador e as lesões apresentavam-se sem cárie e com um envolvimento dentinário de $75 \%$. O esmalte recebeu um acabamento das margens em bisel e seguiram-se as especificações do fabricante para a realização do procedimento adesivo pela técnica úmida. As restaurações foram avaliadas de acordo com os critérios de Ryge nos períodos inicial e um ano. Após um ano, 34 pacientes estiveram disponíveis para a avaliação. O índice de retenção foi de $98,6 \%$, a cor e a descoloração marginal tiveram 95,8\% de escore Alfa, e 83,1\% para a integridade marginal, representada por sobrecontorno e não por fraturas do material e/ou dente. Não houve presença de cárie secundária e sensibilidade pós-operatória. Os autores concluíram que se deve 
ter cuidado com a interpretação dos bons resultados com a técnica do condicionamento ácido total, sendo requerido um período de acompanhamento maior.

van MEERBEEK et al. ${ }^{118}$, em 1993, testaram dois sistemas adesivos comerciais, Tenure e Tripton, em dois tipos diferentes de cavidades em trinta e cinco pacientes. Cento e trinta e duas lesões foram divididas em dois grupos, no Grupo A, as lesões não apresentaram envolvimento de esmalte, e no Grupo B, as lesões foram restauradas com o biselamento do esmalte periférico, com posterior condicionamento ácido. $O$ índice de retenção, a evidência clínica de microinfiltração e a integridade marginal foram monitorados por um período de dois anos. Os resultados indicaram um alto índice de falhas, quando somente a superfície dentinária estava envolvida. O sistema adesivo Tenure apresentou uma perda de $30 \%$ e o Tripton de 55\% após o período de dois anos. Entretanto, o grupo que empregou o condicionamento ácido apresentou um resultado bastante satisfatório, com apenas uma restauração de cada sistema adesivo deslocando-se. Os critérios de evidência de microinfiltração clínica e integridade marginal apresentaram o mesmo comportamento para os dois grupos. Os autores concluíram que a retenção micromecânica promovida pelo condicionamento ácido do esmalte é indispensável para o sucesso clínico de restaurações de lesões cervicais de Classe $\mathrm{V}$ com resina composta.

A união dos sistemas restauradores adesivos àdentina continua sendo um desafio na prática clínica, e com o intuito de contribuir para um melhor entendimento do assunto, van DIJKEN ${ }^{115}$, em 1994, avaliou clinicamente a retenção de quatro sistemas adesivos (Mirage bond, Tenure, Tripton e Scothbond 2) em lesões de erosão e abrasão cervicais por um período de quatro anos. Oitenta e um pacientes, sendo 44 homens e 37 mulheres, participaram do estudo, e um total de 223 restaurações foi confeccionado em lesões de pequena profundidade. Todas as lesões foram restauradas sem a execução de preparo cavitário e não foi utilizado isolamento absoluto. O esmalte periférico àlesão não passou por nenhum tipo de tratamento e não se realizou condicionamento ácido. Os sistemas restauradores 
foram empregados segundo as orientações dos fabricantes, exceto pela falta do condicionamento e o polimento foi realizado após duas semanas. A eficácia clínica dos sistemas adesivos foi determinada pela porcentagem de restaurações perdidas durante o período de avaliação. Os índices de perda de restaurações para os sistemas Mirage bond, Tenure, Tripton e Scothbond 2, foram respectivamente: $38 \%$, $8,5 \%, 30,2 \%$ e $9,6 \%$. Após três anos o índice de falhas aumentou para $73 \%, 51,2 \%$, $83 \%$ e $21,2 \%$, e após quatro anos o índice de perdas das restaurações passou para $74,6 \%, 56,1 \%, 83 \%$ e $23,1 \%$. O sistema adesivo Scothbond 2 apresentou o menor índice de falhas após o período de quatro anos quando comparados com os demais adesivos $(p<0,001)$. $O$ fator idade não foi significante no índice de perda das restaurações, pois os sistemas apresentaram perdas nos três grupos etários estudados. $O$ índice de perda das restaurações em todos os grupos etários após dois anos foi de $88 \%$ do total de falhas observadas durante o estudo.

DUKE et al. ${ }^{30}$, em 1994, delinearam um estudo para avaliar o comportamento clínico do sistema adesivo modificado (Prisma Universal Bond 3) empregado para restaurar lesões cervicais em adultos por um período de dois anos. Concomitantemente ao estudo clínico, realizou-se uma parte laboratorial para caracterização da interface adesiva entre o sistema adesivo e a superfície dentinária através de microscopia eletrônica de varredura e microscopia confocal. Um total de 38 pacientes entre 36 e 72 anos foi dividido em dois grupos com 47 restaurações cada, sendo que no Grupo $A$ as restaurações foram colocadas apenas em superfícies dentinárias, sem envolvimento intencional de esmalte, e no Grupo B, as restaurações foram inseridas em superfícies de esmalte e dentina com biselamento das margens de esmalte e condicionamento ácido do esmalte. Todas as restaurações foram executadas sob isolamento absoluto e avaliadas no baseline, 6 meses, 1 ano e dois anos de acordo com o método de Ryge (USPHS) nos seguintes critérios: retenção, cor, integridade marginal, descoloração marginal, forma anatômica, cárie secundária, sensibilidade pós-operatória e resposta gengival. Os resultados apresentaram $100 \%$ de retorno dos pacientes no período de um ano e $94,7 \%$ ao final de dois anos, com perda de dois pacientes. Ao final do período de avaliação, os dois grupos apresentaram 100\% de retenção para as 81 restaurações 
avaliadas. Os critérios de cor, cárie secundária e forma anatômica permaneceram inalterado durante o período do estudo. As imagens laboratoriais dos sistemas adesivos confirmaram o desempenho clínico favorável apresentado pelos adesivos nesse estudo. Na microscopia confocal uma zona de interdifusão de resina foi observada ao longo da interface dentinária. Esses achados suportam a conclusão de que o principal mecanismo de adesão com esse sistema é a retenção micromecânica.

Com o objetivo de avaliar a reprodutibilidade dos testes de microinfiltração in vitro, FERRARI et al. ${ }^{37}$, em 1994, investigou a habilidade do selamento de três sistemas restauradores adesivos através da comparação dos dados obtidos de microinfiltração in vivo, de restaurações com três meses de serviço clínico com a microinfiltração de restaurações realizadas em dentes extraídos. Para o estudo da microinfiltração in vivo, 29 pacientes voluntários receberam 40 restaurações em dentes comprometidos periodontalmente. Todos os dentes apresentavam-se sem restaurações e os pacientes concordaram em adiar a remoção dos elementos dentários por um prazo de 90 dias para a completa integração com a cavidade bucal. Os dentes receberam um mesmo tipo de preparo, sendo que no Tipo I, todas as margens estavam em esmalte e no Tipo II, a margem cervical estava em cemento/dentina. Os materiais empregados foram: Clearfil Liner Bond, Gluma 2000, restaurados com resina híbrida e com resina de micropartícula e, Scothbond Multi-Purpose. Após o procedimento restaurador e resguardado 0 período de serviço clínico, os dentes foram extraídos e imersos por 24 horas em solução de fucsina básica a $0,5 \%$ e, depois, lavados abundantemente e armazenados por 7 dias em solução de cloramina a 1\%. Para os espécimes in vitro, 40 dentes extraídos receberam o mesmo tipo cavitário e procedimento restaurador que o grupo anterior e, ao final foram armazenados por uma semana em água deionizada e passaram por ciclagem térmica, para enfim serem imersos na solução de fucsina, objetivando que ambos os grupos recebam o mesmo tratamento. A análise foi feita por meio do seccionamento e medição dos escores de penetração do corante. A análise estatística dos dados revelou que os sistemas que mais infiltraram foi o Clearfil Liner Bond e o Scothbond Multi-Purpose em condições in 
vitro, para o tipo cavitário II e nas margens apicais, e não houve diferença nos demais índices de microinfiltração. Os autores concluíram que o resultado do estudo clínico obteve melhores índices de infiltração marginal que o dos espécimes in vitro, entretanto, o resultado de ambos experimentos foi muito similar, indicando que os testes de infiltração laboratoriais podem estimar de uma forma razoável a performance clínica.

TYAS $^{108}$, em 1994, realizou um estudo clínico para verificar a efetividade de sistemas restauradores adesivos na restauração de lesões cervicais de erosão/abrasão. Um total de cem restaurações foi confeccionado e divididas em 5 grupos com vinte restaurações cada. Os sistemas empregados foram: All-Bond, Photobond, Denthesive e Pertac, restaurados com resina composta, e Geristore, uma resina composta modificada por poliácidos. Um total de quinze pacientes participou do estudo, e a média de idade foi de 63 anos. As avaliações foram feitas nos períodos de 3, 6 e 12 meses, através do critério de retenção, no qual o sucesso clínico estava baseado na presença da restauração, a perda total ou parcial era sinônimo de falha da restauração. Ao término no período de avaliação, a porcentagem de restaurações retidas foi: All-Bond 69.6\%, Photobond $78.2 \%$, Denthesive $42.8 \%$, Pertac $7.5 \%$, Geristore $71.8 \%$. O autor concluiu que os resultados estavam em concordância com os estudos laboratoriais de resistência adesiva.

TYAS $^{109}$, em 1994, avaliou o desempenho clínico do sistema adesivo Tenure por um período de três anos. Vinte lesões cervicais foram restauradas em cinco pacientes com média de idade de 58 anos. O procedimento restaurador foi executado sem o condicionamento ácido do esmalte e a resina composta utilizada foi a Silux. O índice de falhas de retenção cumulativa, nos períodos de 1 ano, 2 e 3 anos, respectivamente, foi de 5\%, 5\% e $11 \%$, e houve um discreto aumento da descoloração marginal. $O$ autor conclui que os resultados desse estudo estão em concordância com os demais trabalhos. 
A validação dos testes laboratoriais com os sistemas adesivos requer uma comprovação de sua eficiência clínica, e, dessa forma, van MEERBEEK et al. ${ }^{119}$, em 1994, avaliaram clinicamente sistemas adesivos mais antigos (Scotchbond, Gluma, Clearfil New Bond, Scotchbond 2, Tenure e Tripton) em comparação com os sistemas mais recentes (Bayer exp. 1 e 2, Clearfil Liner Bond System e Scotchbond Multi-Purpose). Um total de 1177 lesões cervicais de 346 pacientes foi restaurado com dois tipos cavitários, no Grupo A, o esmalte não foi biselado nem condicionado, conforme recomendado pela ADA, e no Grupo B, realizou-se o bisel e o condicionamento das margens de esmalte. Os autores concluíram que o índice de retenção clínica demonstrou a superioridade dos novos sistemas adesivos.

MANEENUT; TYAS $^{73}$, em 1995, realizaram um acompanhamento clínico por um período de um ano com cimento de ionômero de vidro modificado por resina em lesões cervicais de abrasão. Sessenta lesões foram restauradas em 13 pacientes, com cada um dos materiais em estudo, divididos em 3 grupos de 20 restaurações cada. Os materiais empregados foram o Fuji II LC, Photac-Fil e o Vitremer, de acordo com as especificações dos fabricantes. Os pacientes foram examinados nos períodos inicial, 6 e 12 meses após a confecção das restaurações, nos critérios de cor, descoloração marginal e retenção. Ao término de um ano, não houve deslocamento de nenhuma restauração. No entanto, em relação ao critério cor, as restaurações de Vitremer apresentaram um escurecimento, sendo diferente estatisticamente dos demais materiais. Todas as restaurações apresentaram um aumento estatisticamente significante na descoloração marginal, entretanto, essa descoloração foi clinicamente insignificante.

TYAS $^{110}$, em 1995, avaliou as diversas nomenclaturas empregadas para designar a perda de estrutura dentária na região cervical dos dentes, como abrasão, erosão, abrasão/erosão, e lesão cervical idiopática. No entanto, muitas dessas lesões não apresentam a aparência e a localização comuns ̀̀ lesões típicas de erosão e/ou abrasão, e, têm aumentado a associação do papel 
do estresse oclusal na etiologia das lesões cervicais. As lesões cervicais não cariosas freqüentemente requerem restauração, sendo que as técnicas restauradoras mais comumente empregadas são a restauração com cimento de ionômero de vidro, restauração com resina composta e o cimento de ionômero de vidro com forramento ou base e finalmente, a restauração de resina composta e sistema adesivo. O autor discute $\mathrm{O}$ emprego das técnicas restauradoras, apresentando resultados de trabalhos, indicando vantagens e desvantagens. O emprego do cimento de ionômero de vidro é indicado como a melhor técnica para restauração das lesões cervicais não cariosas, seguida pela técnica do sanduíche e pela restauração convencional com sistema adesivo.

Alguns estudos laboratoriais apontam a técnica de sanduíche, restauração de resina composta utilizando-se o cimento de ionômero de vidro como agente forrador, como uma técnica que reduz a microinfiltração em comparação com as restaurações de ionômero ou resina composta isoladamente, especialmente em margens cervicais. Com base nesse conceito, POWELL; JOHNSON; GORDON ${ }^{87}$, em 1995, idealizaram um estudo para analisar a performance clínica de restaurações de Classe $\mathrm{V}$ de acordo com os critérios do USPHS. O estudo comparou o desempenho clínico de três técnicas restauradoras em 116 lesões cervicais de erosão e abrasão de 25 pacientes. Cada paciente recebeu no mínimo três técnicas restauradoras, a saber, restauração com cimento de ionômero de vidro (Ketac-Fil), restauração com resina composta e sistema adesivo (Silux Plus e Scothbond 2) e restauração com resina composta e sistema adesivo empregando o cimento de ionômero de vidro como forrador (Silux Plus/Scothbond2 e Vitrebond). O objetivo do trabalho era determinar se uma das técnicas empregadas demonstrava superioridade clínica. Os parâmetros de cor, descoloração marginal, textura de superfície, desenvolvimento de cárie foram comparados e o sucesso clínico foi mensurado pelo índice de retenção das restaurações. Fatores como localização do dente, idade do paciente e oclusão foram analisados para determinar seu efeito no desempenho das restaurações. Ao término dos três anos de avaliação, vinte e quatro pacientes e 110 restaurações foram examinadas. Todas as restaurações apresentaram-se clinicamente aceitáveis para 
os critérios avaliados. No critério textura superficial, as restaurações de cimento de ionômero de vidro apresentaram um desempenho pior do que as restaurações de resina composta. As restaurações de ionômero de vidro e resina composta com ionômero como forrador, apresentaram melhores índices de retenção com 97,3 \% e $100 \%$ respectivamente. No entanto, as restaurações com resina composta e sistema adesivo apresentaram piores índices com $75,7 \%$ de retenção ao final de três anos. $O$ aumento da função oclusal, mobilidade e localização do dente foram associados com a diminuição do índice de retenção.

Com o objetivo de avaliar o melhor material para a restauração de lesões cervicais não cariosas, NEO et $\mathbf{a l}^{81}$., em 1996, conduziram um estudo de avaliação clínica com dois cimentos de ionômero de vidro, um de presa química, o Fuji Cap II, e outro modificado por resina composta, o Fuji II LC, comparativamente com dois sistemas restauradores adesivos, o Prisma Universal Bond 3 (PUB 3)/ APH e o Imperva Bond/Lite Fil II A. Um total de 10 pacientes (4 homens e 6 mulheres) participou do estudo e a média de idade foi de 47 anos. Cada paciente tinha no mínimo quatro lesões cervicais não cariosas a serem restauradas e um total de 83 restaurações foram confeccionadas. Não foi realizado qualquer tipo de preparo cavitário e não foi empregado o dique de borracha para o isolamento do campo operatório. Os materiais foram empregados de acordo com as instruções dos fabricantes, sendo empregado o condicionamento do esmalte nas restaurações de resina composta. As avaliações foram realizadas por dois examinadores independentes utilizando-se o método de Cvar e Ryge modificado para os critérios de cor, descoloração marginal, forma anatômica, adaptação marginal e cárie secundária nos períodos inicial e 18 meses. O critério retenção foi anotado como ausente ou presente. Todos os pacientes estiveram disponíveis ao final da avaliação e nenhuma restauração apresentou cárie secundária. Para o critério cor, o Fuji Cap II (cimento de ionômero convencional) apresentou o pior resultado com apenas duas das 21 restaurações obtendo conceito Alfa no baseline. Entretanto, as restaurações com cimento de ionômero de vidro modificado e com resina composta apresentaram boa reprodução de cor. Com relação àdescoloração marginal, todos os materiais exibiram algum tipo de manchamento nas margens, mas apenas foi estatisticamente 
significante para as restaurações com o PUB 3/APH que apresentaram $50 \%$ das restaurações com conceito Bravo após 18 meses. As restaurações mantiveram a forma anatômica durante o período de avaliação não havendo diferenças significativas entre os materiais. Um número significante de restaurações para os quatro materiais apresentou perda na integridade marginal passando de Alfa para Bravo aos 18 meses. O índice de retenção para o sistema restaurador adesivo Imperva bond/Lite Fil II A foi de 65\%, com 7 restaurações deslocadas. O cimento de ionômero de vidro modificado por resina apresentou apenas uma restauração deslocada com índice de retenção de $95 \%$ e o cimento de ionômero de vidro convencional e o PUB 3/APH apresentaram $100 \%$ de retenção. Os autores concluíram que os sistemas restauradores adesivos não devem ser classificados como um grupo, pois podem apresentar diferentes valores de retenção e que os estudos laboratoriais nem sempre se correlacionam com os dados clínicos.

van MEERBEEK et al. ${ }^{120}$, em 1996, avaliaram o desempenho clínico de quatro sistemas adesivos, sendo dois experimentais da Bayer e dois comerciais, o Clearfil Liner Bond e o Scothbond Multi-Purpose, para restauração de lesões cervicais de Classe V. Quatrocentos e vinte lesões de erosão/abrasão foram restauradas com os quatro sistemas restauradores adesivos, com a variação de dois tipos cavitários, com margens em esmalte biseladas ou não. Os sistemas adesivos comerciais demonstraram altos índices de retenção, em ambos os tipos cavitários, após três anos de acompanhamento. Em contrapartida, os sistemas experimentais apresentaram índices de retenção baixos no mesmo período de avaliação. Nenhum dos sistemas garantiu margens livres de infiltração ao longo do tempo, e a descoloração marginal também seguiu o mesmo padrão que o índice de retenção. Os autores concluíram que os sistemas experimentais apresentaram resultados clínicos insatisfatórios e, embora, os índices de retenção tenham melhorado para os sistemas comerciais, o selamento marginal ainda é um problema a ser solucionado. E, a microinfiltração clínica, ao invés de índice de retenção, pode ser um fator mais efetivo para a avaliação de novos sistemas adesivos. 
A grande maioria dos estudos realizados com sistemas adesivos emprega como substrato para adesão a dentina normal, sem contudo, levar em consideração substratos clinicamente relevantes como a dentina afetada por cárie e a dentina cervical esclerótica. YOSHIYAMA et al. ${ }^{131}$, em 1996, idealizaram um estudo para verificar a variabilidade regional da resistência adesiva através do teste de microtração em regiões oclusal e gengival de superfícies dentinárias de lesões cervicais escleróticas comparativamente àmesma região em lesões preparadas em dentina normal. Os sistemas adesivos empregados foram 0 All Bond 2, Scothbond Multi-Purpose e Clearfil Liner Bond 2. Os resultados indicaram que não há diferença estatisticamente significante entre as resistências adesivas de espécimes feitos na oclusal e gengival em ambos substratos. Entretanto, a resistência adesiva em lesões naturais com dentina esclerótica foram $20 \%$ a $45 \%$ menores do que em dentina normal dependendo do sistema adesivo empregado.

TYAS $^{111}$, em 1996, avaliou clinicamente a performance de cinco sistemas restauradores por um período de três anos. Um total de 100 restaurações (20 por sistema restaurador) foi confeccionada em lesões cervicais de 15 pacientes. Os sistemas utilizados foram: All-Bond, Photobond, Denthesive, Pertac Bond e Geristore, um dos cinco produtos apresenta união pela camada híbrida e os demais apresenta união química àdentina, embora o Photobond e o Geristore apresentem a formação de camada híbrida. As restaurações foram avaliadas por 3 meses, 6 meses, 1, 2 e 3 anos no critério de retenção (presença ou ausência). Os resultados mostraram que não houve diferença entre os materiais com respeito à idade do paciente e a localização do dente. O índice de perda variou de $26 \%$ a $95 \%$ dependendo do sistema empregado. Os sistemas All-Bond e Photobond apresentaram menores índices de falhas com $26 \%$, sendo que $20 \%$ ocorreu nos primeiros seis meses de avaliação. Os sistemas Geristore e Pertac-Bond apresentaram índices de falhas de $69 \%$ e $95 \%$ respectivamente, e isto pode ser devido àdificuldade de apresentar uma un ião química sob a dentina, sugerindo que os próximos desenvolvimentos de união com grupos carboxílicos devam apresentar 
um sistema hidrofilo.

NEO; CHEW $^{80}$, em 1996, avaliaram clinicamente a performance clínica de três modalidades de tratamentos para a restauração de lesões cervicais não cariosas. Cada procedimento restaurador foi avaliado pelos parâmetros de cor, descoloração marginal, forma anatômica, adaptação marginal e retenção por um período de três anos. Dezoito pacientes, sendo 13 homens e 5 mulheres com idades de 22 a 73 anos, foram selecionados para participarem do estudo. Os pacientes apresentavam boa saúde geral, ausência de lesões cariosas extensas, ausência de bruxismo e um mínimo de três lesões cervicais não cariosas, com formatos variados e profundidade axial de no mínimo de $1 \mathrm{~mm}$. Cento e cinquenta e nove restaurações foram confeccionadas com uma das três técnicas restauradoras: 1) cimento de ionômero de vidro, 2) resina composta e sistema adesivo e 3) restauração pela técnica do sanduíche que combina ambos os materiais. Todas as restaurações foram inseridas por um único operador, seguindose as especificações dos fabricantes, inclusive no que diz respeito ao condicionamento ácido do esmalte. O preparo cavitário limitou-se àconfecção do bisel das margens em esmalte para as restaurações de resina composta. As restaurações foram avaliadas no baseline, 1,2 e 3 anos após a execução dos procedimentos. O índice de retorno foi de $100 \%$ em todos os períodos de avaliação. O índice de retenção para o grupo restaurado com resina composta e sistema adesivo foi de $78 \%$, com doze restaurações deslocadas, ao passo que para o grupo restaurado pela técnica do sanduíche e o grupo com cimento ionomérico os índices foram de $96 \%$ e $95 \%$ respectivamente. Em geral, a deterioração marginal foi mais pronunciada do que a descoloração marginal para todos os grupos. Não houve diferenças estatisticamente significantes para o critério forma anatômica, mas as restaurações com o cimento de ionômero de vidro exibiram maior mudança, com $77 \%$ das restaurações com conceito Alfa após três anos. Ao final de três anos, os autores concluíram que as três modalidades restauradoras não apresentaram diferenças estatísticas significantes para os critérios cor, descoloração marginal, forma anatômica e adaptação marginal, embora tenha havido uma deterioração geral das restaurações com o passar do tempo. 
As restaurações de lesões de Classe $V$ têm-se apresentado como um excelente modelo para avaliar a eficácia clínica dos sistemas adesivos. Esse fato é decorrente de numerosos fatores como a natureza não retentiva das lesões, grandes áreas de dentina exposta e margens limitadas de esmalte e o alto grau de flexão do dente com decomposição de forças incidindo sobre a região cervical do dente. Com esse propósito, BOGHOSIAN ${ }^{12}$, em 1996, avaliou o desempenho clínico de um novo sistema adesivo o OptiBond. Oitenta restaurações foram confeccionadas em trinta e cinco pacientes de acordo com os parâmetros estabelecidos pela Academia Dentária Americana para sistemas restauradores adesivos. Ao final de dois anos, todos os critérios clínicos avaliados apresentaram conceitos excelentes com $94 \%$ a $100 \%$ Alfa.

HÖRSTED-BINDSLEV; KNUDSEN; BAELUM ${ }^{58}$, em 1996, avaliaram clinicamente o desempenho de duas formulações para a melhoria do sistema adesivo Gluma. Oitenta dentes (51 maxilares e 29 mandibulares) com lesões de erosão e abrasão na face vestibular foram restaurados em 26 pacientes, sendo 16 mulheres e 10 homens. Cada paciente recebeu um mesmo número de restaurações com as duas formulações adesivas para teste. As avaliações foram feitas no baseline, 1, 2 e 3 anos após a confecção das restaurações, baseando-se nos critérios estabelecidos pelo sistema USPHS e de acordo com o programa de aceitação da Academia Dentária Americana para materiais restauradores estéticos. O índice de retenção foi de $88 \%$ para os dois sistemas, e no que diz respeito à integridade marginal, as mudanças de conceitos Alfa para Bravo durante o período de observação foi devido a fraturas associadas ao sobrecontorno de material restaurador nas margens. Não houve diferença estatisticamente significante para os critérios cor, textura superficial e índices de placa e gengival.

\section{Em 1996, MATIS; COCHRAN; CARLSON ${ }^{74}$ avaliaram} clinicamente, por um período de dez anos, o emprego do cimento de ionômero de vidro na restauração de lesões cervicais não cariosas. Trinta pacientes com no mínimo quatro lesões cervicais receberam um dos procedimentos restauradores a 
seguir: restauração com Ketac-Fil com acabamento imediato; Ketac-Fil com acabamento mediato; Chelon-Fil e restauração com a resina Cervident. É necessário salientar que as lesões não receberam qualquer tipo de preparo cavitário. Após o período de 10 anos, dezoito pacientes compareceram à avaliação. Os índices de retenção para os materiais foram os seguintes: Ketac-Fil com acabamento imediato, 83\%; Ketac-Fil com acabamento retardado, 78\%; Chelon-Fil, 67\% e resina composta Cervident, $17 \%$. Os cimentos de ionômero de vidro apresentaram índices de retenção estatisticamente maiores que a resina composta. Os autores concluíram que o cimento de ionômero de vidro é o material ideal para restauração de lesões de erosão/abrasão cervicais quando um procedimento não invasivo for recomendado, devido ao alto índice de retenção por longos períodos de tempo.

Os sistemas adesivos atuais têm apresentado uma significativa melhoria na união aos substratos dentários, e com o objetivo de avaliar a performance clínica de um sistema adesivo em lesões cervicais de erosão e abrasão, MANDRAS et al. ${ }^{72}$, em 1997, delinearam um estudo clínico em concordância com as diretrizes estabelecidas pela Academia Dentária Americana. Um total de 62 lesões foi restaurado em 25 pacientes, sem a execução de preparo cavitário e com uma grande superfície dentinária exposta (75\%). As lesões foram restauradas com o sistema do Clearfil Liner Bond/Clearfil Photo Anterior e divididas de acordo com o seguinte critério: Tipo I (12) - lesões em forma de V com $1 \mathrm{~mm}$ de profundidade; Tipo II (31) - lesões me forma de V maiores que $1 \mathrm{~mm}$ de profundidade; Tipo III (7) - lesões em forma circular com profundidade de $1 \mathrm{~mm}$ e Tipo IV (12) - lesões circulares com profundidade maior que $1 \mathrm{~mm}$. As restaurações foram avaliadas por dois examinadores nos critérios de cor, descoloração marginal e integridade marginal de acordo com os critérios estabelecidos por Ryge; e ainda pela presença ou ausência de cárie, sensibilidade pré e pós-operatória e falha da restauração devido àperda da retenção ou outras causas. Ao final de três anos, quatro das 55 restaurações remanescentes no estudo falharam devido àfalta de retenção e as avaliações dos outros critérios demonstraram uma performance excelente. Os autores concluíram que os elevados valores de resistência adesiva apresentados pelo sistema Clearfil Liner Bond em testes de cisalhamento 
correlacionam-se bem com uma união estável na cavidade bucal com altos índices de retenção.

ABDALLA; ALHADAINY ${ }^{1}$, em 1997, avaliaram o desempenho clínico de três marcas de cimento de ionômero de vidro modificado por resina e uma resina composta modificada por poliácido em lesões cervicais por um período de dois anos. Oitenta lesões cervicais foram restauradas em 40 pacientes que participaram do estudo. Todas as lesões apresentavam um tamanho similar e localizadas na face vestibular, livre de cárie e, obrigatoriamente, em oclusão. Os dentes foram isolados com dique de borracha e não receberam qualquer tipo de preparo cavitário. Os grupos experimentais foram divididos em quatro com um total de vinte restaurações cada, nos Grupos I, II e III, empregou-se cimento de ionômero de vidro modificado por resina (Fuji II LC, Photac-Fil e Vitremer); no Grupo IV, utilizou-se uma resina composta modificada por poliácido (Dyract). Os materiais foram empregados de acordo com as especificações dos fabricantes e aplicou-se um agente de superfície para todas as restaurações. As avaliações foram executadas por dois examinadores independentes e de acordo com o sistema do USPHS, nos critérios de cor, forma anatômica, adaptação marginal, descoloração marginal e retenção, nos períodos inicial, um ano e dois anos. Após dois anos, 73 restaurações estiveram disponíveis para a avaliação, apresentando um índice de retorno de 92,5\%. O índice de retenção geral foi de 98,6\%, com apenas uma restauração deslocada para o Grupo do Photac-Fil. No critério cor, as porcentagens de escore Alfa foram 85\% para o Fuji II LC, 78\% para o Photac-Fil, 67\% para o Vitremer e $89 \%$ para o Dyract. Para a forma anatômica, 100\% das restaurações de Dyract receberam conceito Alfa, 94\% das restaurações de Photac-Fil e Vitremer tiveram conceitos Alfa e $90 \%$ para as restaurações de Fuji II LC. Todos os grupos apresentaram discrepâncias marginais e descoloração marginal, entretanto não foram estatisticamente significantes. Os autores concluíram que embora todos os materiais tenham apresentado um excelente comportamento clínico no período de dois anos, um acompanhamento mais longo é requerido para estabelecer a real longevidade desses materiais. 
PRATI et al. ${ }^{89}$, em 1997, avaliaram a qualidade marginal do esmalte e da dentina em restaurações de Classe $V$ com vários sistemas restauradores adesivos através do exame de réplicas por microscopia eletrônica de varredura (MEV). Avaliou-se, também, a microinfiltração entre os sistemas restauradores e as paredes cavitárias de esmalte e dentina em diferentes níveis. Cavidades não-retentivas foram preparadas em terceiros molares humanos recémextraídos nas superfícies vestibulares e linguais ao nível da junção cemento/esmalte. Os materiais foram empregados de acordo com as especificações dos fabricantes, sendo utilizados quatro sistemas adesivos (All Bond 2, Clearfil Liner Bond 2, OptiBond FL e Scothbond Multi-Uso Plus) e dois cimentos ionoméricos (Fuji II LC e Vitremer). Várias cavidades foram preparadas e não restauradas para avaliar a morfologia do esmalte e da dentina sem restauração. Imediatamente após o polimento, as restaurações foram moldadas com o polivinilsiloxano para a obtenção de réplicas em resina epóxica. Cada réplica foi observada em MEV para avaliar a morfologia ao longo das margens cervicais em dentina e incisais em esmalte, e, além disso, avaliou-se a presença de fraturas, porosidades e outras alterações ao longo das margens. Cada dente foi armazenado por 24 horas em solução corante para avaliação da microinfiltração circunferencial e longitudinal. A análise da microscopia eletrônica de varredura mostrou que, nas margens em esmalte, houve uma continuidade interfacial (material restaurador/estrutura dentária). Entretanto, a qualidade marginal do esmalte foi grandemente influenciada pelas fraturas de prismas de esmalte, onde em alguns casos os prismas foram removidos e pequenos defeitos na interface eram visíveis. A restauração não se projetou em nenhum caso e raras porosidades, próximas às margens, foram observadas nos compósitos. As margens em dentina apresentaram, em muitos espécimes, discrepâncias marginais e fratura da interface sistema adesivo/resina composta. Entretanto, não houve fraturas coesivas em dentina nos espécimes avaliados. Os procedimentos de acabamento e polimento apresentaram-se bastante agressivos à dentina, com margens em dentina mais desgastadas do que a resina composta. De um modo geral, as restaurações com ionômero de vidro apresentaram menor fratura de esmalte e menores falhas marginais em dentina que as de resina composta. Os autores concluíram que o completo selamento das margens em dentina ainda está 
longe do ideal e a presença de discrepâncias marginais sugere que a contração de polimerização, própria dos materiais resinosos, pode criar um prejuízo \&̀ margens das restaurações acarretando num efeito negativo na sobrevida de restaurações de resina composta.

BURROW; TYAS ${ }^{22}$, em 1998, idealizaram um estudo para verificar a efetividade de um sistema restaurador adesivo empregado para restauração de lesões cervicais não cariosas. Um total de cem lesões foi restaurado em treze pacientes com o cimento de ionômero adesivo Fuji Bond LC e posterior inserção de uma das resinas, Estio LC ou Silux Plus. Os pacientes foram avaliados aos seis e doze meses, nos critérios de retenção, descoloração marginal e cor. Para o critério retenção empregou-se o exame intra-oral, e para os demais critérios utilizou-se a avaliação das fotografias. Ao término de um ano, duas restaurações de Silux Plus deslocaram-se, resultando num índice de retenção cumulativa de $98 \%$. Ao exame fotográfico não houve descoloração das margens das restaurações e a reprodução da cor permaneceu excelente.

GLADYS et al. ${ }^{46}$, em 1998, avaliaram a adaptação marginal e a retenção de materiais empregados para a restauração de lesões cervicais não cariosas por um período de 18 meses. Os materiais utilizados foram o cimento de ionômero de vidro convencional, HIFI Máster Palette, três cimentos de ionômero de vidro modificado por resina, Fuji II LC, Vitremer e um Experimental da 3M, e uma resina composta modificada por poliácidos, Dyract. A avaliação clínica foi realizada nos períodos inicial, 6, 12 e 18 meses, nos critérios de retenção, integridade marginal, microinfiltração clínica, cárie secundária e vitalidade dentária. No caso de perda de restauração e presença de defeitos mais severos, os dentes eram moldados para a confecção de réplicas para examinar, por microscopia eletrônica de varredura, a superfície e as margens das restaurações. No critério retenção, houve um bom desempenho de todos os materiais. As discrepâncias marginais foram localizadas nas margens incisais de esmalte e nas margens cervicais em dentina, exceto para o Dyract, que apresentou maior defeito nas margens de esmalte. Nenhum dos sistemas pode garantir margens livres de microinfiltração por um 
período de tempo longo. Os autores concluíram que o selamento marginal continua sendo um problema, e que as pesquisas futuras deveriam se concentrar na melhoria do selamento marginal antes de se recomendar a utilização dos materiais.

TYAS $^{112}$, em 1998, avaliou a performance clínica de uma resina composta modificada por poliácido (compômero) por um período de um ano. Quarenta e uma restaurações foram confeccionadas em nove pacientes, sendo 36 em lesões cervicais não cariosas e 5 em lesões de Classe III. Os pacientes tinham uma média de idade de 62 anos (50 a 75). O compômero empregado foi o Dyract, e seguiu-se toda a recomendação do fabricante para a realização das restaurações. As avaliações foram conduzidas no baseline e após um ano, e os critérios de cor e descoloração marginal foram avaliados por fotografias padrões. Após um ano, todos os pacientes retornaram para a avaliação e, apenas uma restauração cervical havia deslocado, com índice de retenção de 97\%. Oito restaurações apresentaram algum grau de descoloração marginal. $\mathrm{O}$ autor concluiu que o material apresentou bons resultados em lesões cervicais não cariosas e que é necessário um período maior de acompanhamento do material.

BROWNING; BRACKETT; GILPATRICK ${ }^{19}$, em 1999, iniciaram uma série de projetos com o objetivo de investigar o papel do módulo de elasticidade no sucesso clínico de restaurações de lesões cervicais não cariosas. As diversas classes de materiais restauradores são comparadas e, nesse estudo comparou-se especificamente duas resinas compostas, uma híbrida e outra de micropartícula. Trinta pares de restaurações foram inseridas em 30 pacientes, sendo que cada paciente recebeu apenas duas restaurações com os materiais em estudo, Silux Plus e Z-100. A idade dos pacientes variou de 40 a 75 anos e o sistema adesivo Scothbond Multi-Uso foi utilizado em todos os casos. Os materiais foram empregados segundo as especificações do fabricante, sendo realizados acabamento do ângulo cavo-superficial na forma de bisel e condicionamento do esmalte e da dentina. As avaliações foram feitas no baseline, 6 e 12 meses, por dois examinadores independentes, e de acordo com os critérios desenvolvidos por Cvar e Ryge. Os resultados indicaram um índice de retenção de $97 \%$ para ambos os 
materiais, com uma restauração de cada material tendo se deslocado. De uma forma geral não houve diferenças entre os materiais nos diferentes critérios avaliados. Futuras avaliações serão publicadas para averiguar o desempenho dos materiais.

BRACKETT et al. ${ }^{15}$, em 1999, elaboraram um projeto com o objetivo de comparar o desempenho clínico de dois materiais utilizados para restauração de lesões cervicais, sendo um compômero e um cimento de ionômero de vidro modificado por resina. O estudo foi conduzido por um período de um ano, e, um total de 31 pacientes recebeu 34 pares de restaurações, com os materiais em estudo, o Compoglass e o Fuji II LC. Nenhum paciente recebeu mais que dois pares de restaurações. As lesões cervicais foram restauradas sem a realização de preparo, e de acordo com as instruções dos fabricantes, exceto pelo condicionamento ácido da estrutura dentária nas restaurações do compômero (Compoglass). As restaurações foram avaliadas por dois examinadores nos períodos inicial, 6 e 12 meses, empregando-se o sistema do USPHS. O critério que recebesse o conceito Charlie significava falha da restauração. Trinta e um pares de restaurações estiveram disponíveis no retorno de um ano, resultando num índice de retorno de 95\%. A porcentagem de escores Alfa, nos critérios avaliados, para o Compoglass e o Fuji II LC foram respectivamente: retenção (84/100); cor (81/100); descoloração marginal (78/97); cárie secundária (88/100); forma anatômica (92/100) e integridade marginal (26/46). Houve uma diferença estatisticamente significante no índice de falhas entre os materiais. Ambos os materiais apresentaram um selamento marginal insatisfatório, entretanto, de uma forma geral o cimento de ionômero modificado apresentou um desempenho clínico mais favorável que o compômero. Os autores sugerem um período de acompanhamento mais longo para verificar melhor as diferenças entre os materiais.

BRACKETT et al. ${ }^{14}$, em 1999, dando continuidade ao protocolo de avaliação de diferentes materiais para restauração de lesões cervicais não cariosas, avaliaram por um período de dois anos, a performance clínica de dois cimentos de ionômero de vidro, um convencional e outro modificado por resina composta. Trinta e quatro pares de restaurações foram confeccionados em 29 
pacientes, com idades de 30 a 73 anos, e média de 45 anos. Cada paciente recebeu um número igual de restaurações e nenhum paciente recebeu mais que dois pares. Os materiais utilizados foram o Ketac-Fil e o Photac-Fil, não houve qualquer tipo de preparo cavitário, e as lesões apresentavam diversas profundidades axiais. Ao final de dois anos, o índice de retorno foi de $85 \%$ e o índice de retenção para ambos os materiais foi de $93 \%$. O aspecto estético das restaurações foi semelhante com 86 a $88 \%$ das restaurações recebendo escore Alfa. Entretanto, duas restaurações, sendo uma de cada material, desenvolveram lesões cariosas, num mesmo paciente. Os autores concluíram que ambos os materiais apresentaram comportamentos clínicos semelhantes, e que os índices apresentados são suficientes para total aceitação do programa de aceitação da ADA para sistemas adesivos.

A restauração de lesões cervicais não cariosas sem a realização de preparo cavitário têm dado suporte a inúmeros estudos de sistemas adesivos. BURROW; TYAS ${ }^{23}$, em 1999, avaliaram o índice de retenção desses tipos de lesões empregando um sistema adesivo de frasco único associados a materiais de diferentes módulos de elasticidade. Cento e cinco lesões cervicais foram restauradas em 14 pacientes, com idades de 31 a 77 anos. Os grupos experimentais foram restaurados com o mesmo sistema adesivo, One-Step, sendo divididos em 3 grupos com 35 restaurações cada, dois com resinas de baixo módulo de elasticidade (AEliteflow e Bisco Glaze) e o outro com a resina de micropartícula (Silux Plus). O procedimento restaurador foi realizado seguindo-se as especificações dos fabricantes, não sendo realizado qualquer tipo de preparo cavitário, entretanto, a superfície dentinária foi ligeiramente abrasionada com uma ponta diamantada em baixa velocidade. As restaurações foram avaliadas nos períodos de seis meses e um ano nos critérios de retenção e reprodução de cor, através da avaliação de diapositivos. Aos seis meses, todas as restaurações estavam presentes e nenhuma descoloração marginal foi detectada. O exame visual e de diapositivos mostrou uma excelente reprodução da cor dos dentes, exceto para as restaurações de Bisco Glaze. Depois de mais seis meses, um paciente com 4 restaurações não compareceu àav aliação e cinco restaurações foram perdidas por deslocamento, sendo duas de Silux Plus e três de Aeliteflow. Um pequeno número de restaurações 
exibiu descoloração marginal, devido a excesso de material restaurador em áreas não condicionadas e não removidos após o polimento. Os autores concluíram que os novos sistemas restauradores adesivos empregando adesivos que formam a camada híbrida têm uma performance clínica satisfatória e que não houve diferença entre as resinas de baixo módulo de elasticidade e a resina de micropartícula no que diz respeito àretenção das restaurações.

Com o objetivo de avaliar a influência do módulo de elasticidade dos materiais no índice de retenção de restaurações de lesões cervicais não cariosas, BROWNING; BRACKETT; GILPATRICK ${ }^{20}$, em 2000, avaliaram por um período de dois anos a performance clínica de duas resinas compostas de diferentes módulos de elasticidade. Trinta pares de restaurações foram inseridas em 30 pacientes, sendo que cada paciente recebeu apenas duas restaurações com os materiais em estudo, Silux Plus e Z-100. Vinte e oito pares de restaurações estiveram disponíveis para a avaliação de dois anos, e 21 pares de restaurações, de ambos os materiais, apresentaram conceito Alfa no critério retenção, 4 pares de Z100 foram deslocadas e tiveram conceito Charlie e, também, 3 pares de Silux Plus falharam. Isto resultou num índice de retenção de $89 \%$ para a resina Silux Plus e $86 \%$ para a Z-100, o qual não apresentou diferenças estatisticamente significantes no período de dois anos, levando-se a refletir qual a relevância do módulo de elasticidade dos materiais na retenção de restauração de lesões cervicais não cariosas.

di LENARDA; CADENARO; DORIGO ${ }^{28}$, em 2000, avaliaram clinicamente o desempenho de um compômero por um período de quatro anos, analisando a influência do condicionamento ácido. Sessenta lesões cervicais, 24 cariosas e 36 não cariosas, foram divididas em dois grupos de trinta e restauradas com Dyract. Os grupos experimentais foram caracterizados da seguinte forma: Grupo I, as lesões não foram condicionadas e no Grupo II, as lesões foram condicionadas com ácido fosfórico por trinta segundos. As restaurações foram avaliadas a cada seis meses, num período de quatro anos, de acordo com os critérios do sistema USPHS, com algumas modificações. Em ambos os grupos os 
índices de retenção foram elevados e não houve diferenças estatísticas entre eles. Aos dois anos não houve perda de restaurações, e aos quatro anos, o índice de perda foi de $13 \%$ para o Grupo I e 10\% para o Grupo II. Os critérios cárie secundária e sensibilidade foram ausentes no grupo condicionado e de incidência baixa para o grupo não condicionado, com 6,7\% em ambos os casos, entretanto, não houve diferenças estatísticas entre os materiais. Os dois casos de cárie secundária desenvolveram-se aos 48 meses. O critério desgaste foi irrelevante com uma incidência de $6,7 \%$ em ambos os grupos. Para os critérios de descoloração e integridade marginal, houve diferenças estatisticamente significantes entre os grupos, com o grupo não condicionado apresentando $40 \%$ e $\quad 36,7 \%$ respectivamente, e o grupo condicionado 16,7 e 13,3\%. Os autores concluíram que o Dyract teve um desempenho clínico aceitável, e que a adaptação marginal é melhorada com o condicionamento ácido.

A grande maioria dos sistemas adesivos disponíveis no mercado apresenta como mecanismo da ação a interação com o substrato dentinário por meio da formação da camada híbrida, a qual é formada pela difusão dos componentes hidrofílicos dos sistemas adesivos pela trama colágena exposta através do condicionamento ácido. TYAS; BURROW ${ }^{113}$, em 2000, avaliaram a performance clínica de um sistema adesivo, EBS, em lesões cervicais não cariosas. Um total de quarenta restaurações foi confeccionado em oito pacientes, com média de idade de 53 anos. O procedimento adesivo foi realizado de acordo com as instruções do fabricante, o qual consiste, essencialmente, do condicionamento do esmalte e dentina por 20 segundos com o ácido fosfórico a $32 \%$, e posterior aplicação e evaporação do EBS Primer, seguido da aplicação e fotopolimerização do adesivo EBS e restauração da lesão com Pertac II (ESPE). As restaurações foram fotografadas nos períodos inicial e após um ano para a avaliação da descoloração marginal através de uma escala linear contínua. Ao término de um ano, um paciente com quatro restaurações não foi localizado e as demais 36 restaurações foram avaliadas. Uma restauração foi perdida, resultando num índice de retenção cumulativa de $97 \%$. Apenas uma das 35 restaurações apresentou uma discreta descoloração marginal. 
van DIJKEN ${ }^{116}$, em 2000, elaborou um estudo para verificar a efetividade de três sistemas restauradores para a restauração de lesões cervicais não cariosas, sendo dois sistemas adesivos e um cimento de ionômero de vidro. Um total de 148 lesões foi confeccionado em 60 pacientes (31 homens e 29 mulheres), com idades entre 29 e 88 anos, e média de 57 anos. As restaurações foram realizadas por um único operador, com um mínimo de um e o máximo de três restaurações por material. As lesões foram categorizadas em termos de profundidade, divididas em superficial, moderada e profunda e esclerose dentinária, dentina normal, menos que $50 \%$ de esclerose e mais que $50 \%$ de esclerose. As lesões foram restauradas segundo as especificações dos fabricantes, inclusive com condicionamento ácido do esmalte e dentina para os sistemas adesivos, entretanto o biselamento das margens não foi executado. Os sistemas restauradores empregados foram o EBS/Pertac Hybrid, o One-Step/Prisma TPH e o Fuji II LC, onde o primeiro é um adesivo de três passos, o segundo, de passo único e o último um cimento de ionômero de vidro modificado por resina composta. As restaurações foram avaliadas no baseline e a cada seis meses, por um período de três anos, nos critérios de adaptação marginal/retenção, cor, descoloração marginal, cárie secundária e textura superficial, empregando o sistema do USPHS. A eficácia da união foi estabelecida pela porcentagem de restaurações perdidas durante o período de avaliação. Seis restaurações deixaram de ser avaliadas no período de três anos, o índice de perda acumulada em 12 meses foi de $2 \%$ para os sistemas EBS e Fuji II LC e, 24\% para o One-Step. Aos três anos os sistemas EBS, One-Step e Fuji II LC tiveram, respectivamente uma perda de 10\%, 49\% e 7\%. O sistema adesivo de passo único mostrou um elevado número de falhas. As cinco restaurações perdidas do sistema EBS foram oriundas de lesões não escleróticas, entretanto as três restaurações perdidas do ionômero foram de lesões escleróticas. Para o sistema One-Step, $65,2 \%$ das lesões perdidas foi de dentina esclerótica e $31,8 \%$ de dentina não esclerótica. $O$ autor concluiu que o sistema adesivo de passo único apresentou um índice de retenção insatisfatório num curto período de tempo (6 meses) e que não ficou confirmado que a esclerose dentinária interfira negativamente na retenção clínica dos sistemas adesivos. 
SAKOOLNAMARKA et al. ${ }^{97}$, em 2000, examinaram lesões cervicais não cariosas $\mathrm{e}$ as modificações estruturais que ocorrem após 0 condicionamento ácido da dentina. A metodologia incluiu três tipos de lesões, sendo nove em formato de cunha, nove em formato circular e cinco preparos realizados em terceiros molares. Todas as lesões tinham como característica uma superfície dura, lisa e sem descoloração. Os dentes foram seccionados e divididos em três grupos com cada um contendo os três tipos de lesões. No Grupo I, não houve tratamento de superfície, e nos grupos II e III, as superfícies dentinárias foram tratadas com ácido fosfórico a $35 \%$ e ácido poliacrílico a $25 \% /$ cloreto de alumínio a $3 \%$, respectivamente. As superfícies das lesões foram examinadas por microscopia eletrônica de varredura num campo de emissão e microscopia de força atômica. Os resultados indicaram que as lesões preparadas apresentaram smear layer, independente do tratamento de superfície. $O$ tratamento com os ácidos removeu a smear layer, embora no ácido poliacrílico tenha sido encontrado um resquício de lama dentinária. As imagens das lesões sem tratamento da superfície dentinária apresentaram uma dentina altamente mineralizada e completa obliteração dos túbulos dentinários. Após o tratamento ácido, as imagens revelaram desmineralização da superfície, a qual foi mais pronunciada para o ácido fosfórico. Os autores concluíram que o depósito mineral na superfície das lesões diminuiu o efeito do condicionamento ácido.

O desenvolvimento de novos materiais como o cimento de ionômero de vidro modificado por resina e resinas compostas modificadas por poliácidos têm aumentado o número de materiais disponíveis para a restauração de defeitos cervicais. Com o objetivo de avaliar o comportamento clínico desses materiais, FOLWACZNY et al. ${ }^{39}$, em 2000, elaboraram um estudo de acompanhamento por um período de dois anos. Cento e noventa e sete lesões foram restauradas em 37 pacientes, sendo 69 casos de lesões não cariosas, 57 casos de lesões cariosas e 71 casos de substituições de restaurações. Os dentes foram aleatoriamente divididos em quatro grupos, empregando-se no Grupo A, a resina composta Tetric com 36 casos, no Grupo B, o compômero Dyract em 79 
casos, no Grupo C, 51 casos com o cimento de ionômero modificado por resina, Fuji II LC, e no Grupo D, a mesma classe de material que o anterior, utilizando-se o Photac-Fil em 31 casos. Os materiais foram utilizados de acordo com as especificações dos fabricantes, inclusive com a confecção do bisel e condicionamento ácido para as restaurações de resina composta. As restaurações foram avaliadas de acordo com o sistema do USPHS, nos períodos inicial, 8 e 24 meses. Ao término de dois anos, as restaurações de resina composta apresentaram resultados superiores em relação aos demais grupos. As restaurações com o compômero apresentaram um desempenho próximo àresina composta e um grande número de restaurações com o cimento de ionômero de vidro apresentaram escores Bravo ou Charlie em no mínimo um dos critérios avaliados.

FOLWACZNY et al. ${ }^{38}$, em 2000, realizaram um estudo para verificar as mudanças superficiais ocorridas nas restaurações executadas no seu estudo anterior, por um período de três anos, através do emprego de um scanner a laser em três dimensões. As imagens foram superpostas automaticamente e realizou-se uma digitalização por subtração por meio de software especialmente desenvolvido para tanto. A perda total de substância, em mícrons, da superfície das

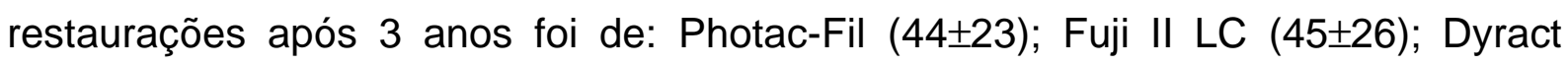
$(71 \pm 47)$ e Tetric (18 \pm 12$)$. As restaurações das lesões cervicais não cariosas foram as que apresentaram maiores índices de desgaste entre os outros tipos cavitários restaurados (66 233$)$. Os autores concluíram que a resina composta apresentou um grau de desgaste significantemente menor que os outros materiais empregados.

FOLWACZNY et al. ${ }^{40}$, em 2001, publicaram os resultados clínicos do mesmo estudo por um período de três anos e os resultados gerais foram bastante semelhantes aos apresentados na avaliação de dois anos. No critério cor, as porcentagens de escores Alfa, para Tetric, Dyract, Fuji IILC e Photac Fil, foram respectivamente, $86,77,58$ e 40 . Seguindo a mesma disposição dos materiais, para textura de superfície os resultados foram: 81, 83, 16 e 9. A integridade marginal em dentina apresentou os valores de 86, 70, 55 e 61 e a descoloração marginal de 82 , 
84, 71 e 48. A forma anatômica apresentou os valores de $91 \%$ para Tetric, $83 \%$ para o Dyract, 39\% para o Fuji II LC e 35\% para o Photac-Fil. O número de restaurações deslocadas foi de uma para a resina composta, cinco de compômero, duas para o Fuji II LC e três para o Photac-Fil. Entretanto, não houve diferenças estatisticamente significantes entre os materiais para o critério retenção. O compômero deve ter apresentado o maior número de falhas de retenção devido a não utilização do condicionamento ácido do esmalte. A resina composta apresentou a melhor performance clínica geral, seguida das restaurações de compômero. E, como pode ser comprovado pelos resultados, os cimentos de ionômero de vidro modificado por resina apresentaram os piores resultados.

FOLWACZNY et al. ${ }^{41}$, em 2001, publicaram os resultados parciais dos estudos anteriores por um período de cinco anos, analisando o desempenho de apenas dois sistemas restauradores (compômero e cimento de ionômero de vidro modificado por resina) em lesões cervicais não cariosas. Dezesseis pacientes receberam um total de 46 restaurações, sendo 18 com o Fuji II LC, um cimento de ionômero de vidro modificado por resina e 28 com o compômero Dyract. As lesões foram restauradas sem a confecção de preparo cavitário e não se empregou o dique de borracha para o isolamento do campo operatório. Após cinco anos, 14 pacientes estiveram disponíveis para o retorno e 34 restaurações foram examinadas. Nenhuma restauração apresentou cárie secundária durante o período de cinco anos de avaliação, cinco restaurações de Dyract e quatro restaurações de Fuji II LC receberam conceitos Charlie ou Delta em um dos critérios avaliados e tiveram que ser substituídas. Não houve perda de restauração por deslocamento para o ionômero de vidro, entretanto, quatro restaurações de compômero deslocaram-se. Os materiais apresentaram diferenças estatísticas significantes em quase todos os critérios avaliados, exceto para a integridade marginal e descoloração marginal em margens de esmalte. Os autores concluíram embora um número elevado de restaurações de compômero tenha se deslocado, não houve diferenças estatísticas entre os materiais e, considerando as restaurações presentes, o compômero apresentou um desempenho clínico superior ao cimento de ionômero de vidro na restauração de lesões cervicais não cariosas no período de 
cinco anos.

BRACKETT et al. ${ }^{16}$, em 2001, compararam por um período de dois anos a performance clínica do cimento de ionômero de vidro modificado por resina (CIVMR) e uma resina composta modificada por poliácido (RCMP) em lesões cervicais não cariosas. As setenta e oito lesões não receberam qualquer tipo de preparo cavitário, e foram colocadas em 31 pacientes. Os materiais empregados foram o Fuji II LC (CIVMR) e o Compoglass (RCMP). No final do estudo, 32 pares de restaurações estiveram disponíveis, resultando num índice de retorno de 94\%. As restaurações de Fuji II LC tiveram um desempenho melhor, obtendo maior número de escore Alfa em todas as categorias. Três restaurações de Compoglass apresentaram cárie, no primeiro ano de avaliação, e cinco restaurações falharam por deslocamento. Os autores concluíram que o cimento de ionômero de vidro modificado por resina apresentou um desempenho clínico superior à resina composta modificada por poliácidos.

TYAS; BURROW ${ }^{114}$, em 2001, apresentaram o resultado de três anos de uma avaliação de um sistema restaurador na resolução de casos de lesões cervicais não cariosas. Treze pacientes, com média de idade de 60,5 anos, receberam 100 restaurações de resina composta, Silux Plus ou Estio LC (50 de cada material), empregando o cimento de ionômero de vidro modificado Fuji Bond LC como agente de união. Ao final de três anos, todas as restaurações de Estio LC e 94\% das restaurações de Silux Plus estavam presentes, resultando num índice cumulativo de $97 \%$. No critério integridade marginal, as restaurações tiveram um índice satisfatório de resultados com 95\% para o Silux e 98\% para o Estio LC, e não houve diferença estatisticamente significante entre os materiais.

SWIFT JUNIOR ${ }^{104}$, em 2001, avaliaram a performance clínica de dois sistemas adesivos de frasco único, sendo um com carga e outro sem carga. Um total de 101 restaurações foram confeccionadas em 33 pacientes, com um número próximo para cada sistema adesivo. Os sistemas adesivos empregados foram: Optbond Solo/Prodigy e Prime \& Bond 2.1/TPH Spectrum. Não foi realizado 
qualquer tipo de preparo cavitário, apenas a superfície dentinária foi abrasionada com uma ponta diamantada. As restaurações foram avaliadas nos períodos inicial, 6 e 18 meses, seguindo-se os critérios modificados do USPHS. Ao término da avaliação, o índice de retenção foi de $93,6 \%$ para o Optibond Solo e $98 \%$ para o Prime \& Bond 2.1, o qual não foi estatisticamente significante. Nos critérios descoloração e integridade marginal, as restaurações com o sistema adesivo com carga obtiveram $91 \%$ de escore Alfa, enquanto as restaurações com sistema adesivo sem carga apresentaram 94 e 100\% respectivamente. As diferenças entre os escores não foram estatisticamente significantes. Os autores concluíram que ambos sistemas adesivos apresentaram um ótimo índice de retenção, superando as diretrizes da ADA para completa aceitação do material. Qualquer benefício oriundo do emprego de adesivo carregado não pôde ser detectado no período em estudo, sugerindo um período maior de avaliação.

SWIFT JUNIOR ${ }^{105}$, em 2001, apresentaram o acompanhamento de três anos do estudo anterior, e os resultados foram similares ao apresentado no período de dezoito meses. O índice de retenção foi de 93,3\% para o Optibond Solo e $89,4 \%$ para o Prime \& Bond 2.1, o qual não foi estatisticamente significante. O critério descoloração marginal apresentou um índice de $12 \%$ para ambos adesivos, e não houve desenvolvimento de cárie. Os autores concluíram que ambos adesivos apresentaram um excelente índice de retenção ao final de trinta e seis meses, e quando os materiais são empregados de forma apropriada, as restaurações permanecem retidas durante um período de no mínimo três anos de vida clínica. 


\section{PROPOSIÇÃo}

Testar a hipótese de que o sistema restaurador adesivo (Excite - Tetric Ceram/Vivadent) e o cimento de ionômero de vidro modificado por resina (Vitremer/3M) proporcionarão comportamentos clínicos semelhantes, no que diz respeito à retenção, integridade marginal, descoloração da margem cavosuperficial, manutenção da forma anatômica (desgaste), cárie secundária e sensibilidade pós-operatória, nos períodos de tempo de avaliação estipulados quais sejam: imediato (baseline), seis meses e doze meses e vinte e quatro meses. 


\section{MATERIAL E MÉTODOS}

\subsection{Seleção de Pacientes}

Os pacientes selecionados para o presente estudo eram oriundos da clínica de pós-graduação da Faculdade de Odontologia de Bauru e da Polícia Militar. Inicialmente, foi necessária a presença de no mínimo duas lesões cervicais não cariosas por paciente, independentemente de sua localização na arcada dentária. Foram utilizados trinta pacientes voluntários de ambos os sexos (7 mulheres X 23 homens), com idades entre vinte três a sessenta e oito anos, com média de 39 anos, os quais após esclarecimentos acerca do trabalho a ser executado e, em concordância, assinaram um termo de aceitação para a realização do estudo. Nesse termo, os pacientes eram orientados quanto ao tipo de tratamento a ser executado, o material empregado, e se comprometiam a colaborar com o estudo, principalmente quando fossem chamados para as avaliações das restaurações. Uma ficha clínica, especialmente confeccionada, com todos os dados pessoais e informações normalmente solicitadas ao se fazer a anamnese, foi preenchida, e a partir de então os pacientes foram integrados definitivamente no estudo. As Figuras 1, 2 e 3 mostram respectivamente os modelos de carta de informação ao paciente, termo de consentimento livre e esclarecido e ficha clínica.

Os critérios para a inclusão dos pacientes neste estudo foram: adequada higiene oral, baixo índice de cárie, ausência de doença periodontal e hábitos parafuncionais, presença de no mínimo duas lesões cervicais não cariosas a serem restauradas com os materiais restauradores em estudo. 
UNIVERSIDADE DE SÃO PAULO

FACULDADE DE ODONTOLOGIA DE BAURU

DEPARTAMENTO DE DENTÍSTICA, ENDODONTIA E MATERIAIS DENTÁRIOS

Título do Projeto:

Responsáveis pelo Projeto:

Neste estudo serão confeccionadas restaurações com uma resina composta e um cimento de ionômero de vidro, em dentes que apresentem lesões cervicais de etiologia não cariosa. Trata-se de procedimentos corriqueiros em clínica odontológica e necessários ao bem estar da saúde do paciente. Os materiais utilizados encontram-se disponíveis no mercado e foram previamente estudados através de testes de comportamento físico e estudos prévios de biocompatibilidade, não demonstrando nenhum risco àintegridade do ser humano.

Assim sendo, dou pleno consentimento àFaculda de de Odontologia de Bauru para, por intermédio de seus professores e alunos de pós-graduação, devidamente autorizados, fazer diagnóstico, planejamento, fotografia, moldagens, tratamento e pesquisa em minha pessoa, de acordo com os conhecimentos enquadrados no campo dessa especialidade.

Concordo também, que a documentação referente aos exames efetuados e quaisquer outras informações concernentes ao planejamento de diagnóstico e/ou tratamento, constituem propriedade exclusiva dessa Faculdade, àqual dou plen o direito de uso para fins de ensino e divulgação, respeitados os respectivos códigos de ética. Estando disponível, disponho-me a participar de futuras reavaliações $(6,12$ e 24 meses) para controle.

Bauru, de de 2000.

\section{Assinatura do Paciente}

Documento apresentado: $\mathrm{N}^{\mathrm{o}}$

FIGURA 1 - Modelo de carta de informação ao paciente 
UNIVERSIDADE DE SÃO PAULO

FACULDADE DE ODONTOLOGIA DE BAURU

DEPARTAMENTO DE DENTÍSTICA, ENDODONTIA E MATERIAIS DENTÁRIOS

Título do Projeto:

Responsáveis pelo Projeto:

NOME:

FICHA N ${ }^{\mathrm{O}}$

Por este instrumento que atende æ̀̀ exigências legais, o(a) senhor(a) portador (a) da cédula de identidade no. SSP $/$ , após leitura minuciosa da CARTA DE INFORMAÇÃO AO PACIENTE, devidamente explicada pelo(s) profissional(is) em seus mínimos detalhes, ciente dos serviços e procedimentos aos quais será submetido, não restando quaisquer dúvidas a respeito do lido e do explicado, firma seu CONSENTIMENTO LIVRE E ESCLARECIDO em concordância de participar da pesquisa proposta no que lhe é cabível, conforme CARTA DE INFORMAÇÃO AO PACIENTE.

Fica claro que o paciente e/ou seu representante legal podem, a qualquer momento, retirar seu CONSENTIMENTO LIVRE E ESCLARECIDO e deixar de participar do estudo alvo da pesquisa e ciente que todo trabalho realizado torna-se informação confidencial guardada por força do sigilo profissional (Art. $9^{\circ}$ do Código de Ética Odontológica).

Por estarem entendidos e conformados, assinam o presente termo.

Bauru, de de 2000.

Assinatura do Paciente

Responsável pelo estudo 
UNIVERSIDADE DE SÃO PAULO

FACULDADE DE ODONTOLOGIA DE BAURU

DEPARTAMENTO DE DENTÍSTICA, ENDODONTIA E MATERIAIS DENTÁRIOS

NOME:

FICHA N $N^{O}$

Gênero: $M(\quad) \quad F(\quad) \quad$ Idade: Data de Nascimento:

Profissão:

Endereço Comercial:

Telefone:

Endereço Residencial:

Telefone:

Telefone para Recados (Amigo/Parente):

\section{QUESTIONÁRIO DE SAÚDE}

01- Está sob tratamento médico?

02- Já teve hemorragia?

03- Sofre (u) de algum tipo de alergia?

04- Já teve reumatismo infeccioso?

05- Sofre (u) de distúrbios cardiovasculares?

06- Sofre (u) de gastrite ou úlcera?

07- É diabético ou possui diabéticos na família?

08- Já desmaiou alguma vez?

09- Está tomando algum medicamento?

10- Esteve doente, internado ou foi operado nos últimos 5 anos?

11- Tem hábitos, vícios ou manias?

$\mathrm{Eu}$, , portador do documento

$\mathrm{n}^{\mathrm{o} .}$ , declaro, para a realização deste estudo, serem verdadeiras

minhas declarações. Assumo os riscos de quaisquer eventuais problemas durante a execução de meu tratamento, decorrente de minha negligência ou omissão ao fornecer as informações acima.

Bauru, de
Motivo?

Devido a quê?

A quê?

Quando?

Qual?

Quem?

Porquê?

de 2000.

Assinatura do Paciente ou Responsável

FIGURA 3 - Modelo de ficha clínica, de dados pessoais e anamnese (Frente) 
UNIVERSIDADE DE SÃO PAULO

FACULDADE DE ODONTOLOGIA DE BAURU

DEPARTAMENTO DE DENTÍSTICA, ENDODONTIA E MATERIAIS DENTÁRIOS

NOME:

FICHA NO:

IDADE:

SEXO:

DATA:

END: TEL:( )

N으: COMPL: BAIRRO:

NOME: PARENTESCO

END: TEL:( )

N으. COMPL:

BAIRRO:

NOME:

PARENTESCO

END:

TEL:( )

$\mathrm{N}$ 으.

COMPL::

BAIRRO:

\section{ODONTOGRAMA}

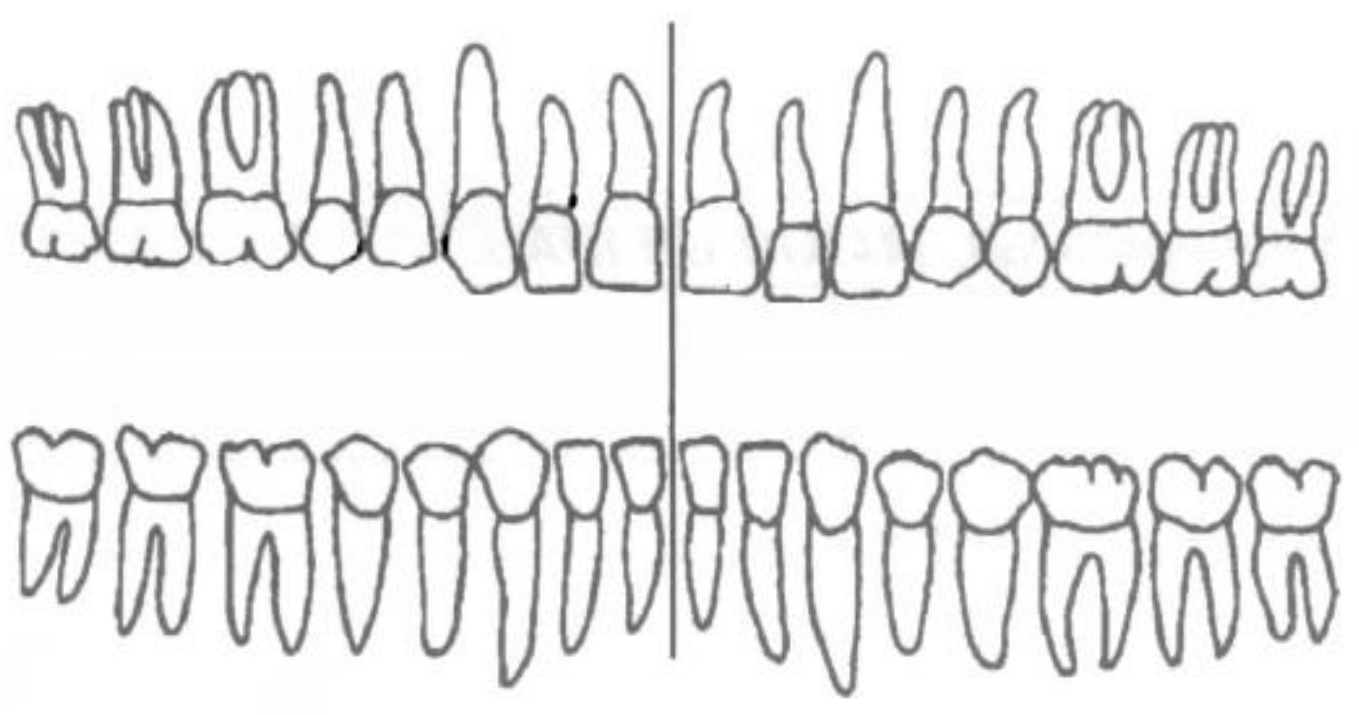

FIGURA 3 - Modelo de ficha clínica, de dados pessoais e anamnese (Verso) 


\subsection{SeleçÃo dos DenTeS}

Os dentes utilizados neste estudo apresentavam lesões cervicais não cariosas, com profundidades iguais ou superiores a $1 \mathrm{~mm}$, de etiologias diversas, independentemente de sua localização na arcada dentária. Preferencialmente, os dentes selecionados eram hígidos ou restaurados satisfatoriamente, sem presença de inflamação gengival ou alterações periapicais e em oclusão. Para tanto, realizou-se um criterioso exame clínico e radiográfico, verificando-se, também, a sensibilidade tátil da superfície dentinária a ser restaurada com o auxílio de uma sonda exploradora ํㅡㄴ. Esses procedimentos visavam ao diagnóstico da condição clínica pré-operatória.

Um total de setenta dentes foi restaurado, sendo trinta e cinco com o sistema restaurador adesivo (Excite/Tetric Ceram - Vivadent), denominado de grupo 1 , e os demais com o cimento de ionômero de vidro modificado por resina (Vitremer Primer/Vitremer - 3M), denominado grupo 2. A Tabela 1 descreve a divisão dos grupos experimentais e o número de restaurações por material utilizado. Vinte e seis pacientes receberam duas restaurações, três pacientes receberam quatro restaurações e apenas um paciente recebeu seis restaurações. A Tabela 2 representa a distribuição dos grupos dentários restaurados com os materiais avaliados.

TABELA 1 - Materiais empregados, número de grupos e restaurações

$\begin{array}{ccc}\text { GRUPO } & \text { MATERIAL } & \text { No DE RESTAURAÇÕES } \\ \text { I } & \text { EXCITE/TETRIC-CERAM } & 35 \\ \text { II } & \text { VITREMER-PRIMER/VITREMER } & 35\end{array}$


TABELA 2 - Número de restaurações realizadas por grupo dentário

\begin{tabular}{cccccccc} 
MATERIAL & \multicolumn{9}{c}{$\begin{array}{c}\text { SUPERIOR LOCALIZAÇÃO } \\
\text { I }\end{array}$} & PM & M & $\begin{array}{c}\text { INFERIOR } \\
\text { PM }\end{array}$ & TOTAL \\
$\begin{array}{c}\text { RESINA } \\
\text { COMPOSTA }\end{array}$ & $\mathbf{1}$ & $\mathbf{3}$ & $\mathbf{1 8}$ & $\mathbf{4}$ & 9 & 35 \\
$\begin{array}{c}\text { CIMENTO DE } \\
\text { IONOMERO DE } \\
\text { VIDRO }\end{array}$ & $\mathbf{1}$ & $\mathbf{2}$ & $\mathbf{2 3}$ & $\mathbf{1}$ & $\mathbf{8}$ & 35 \\
& & & & & & \\
\end{tabular}

\subsection{Procedimento Restaurador}

Previamente à execução das restaurações, alguns procedimentos foram executados, tais como profilaxia com pedra-pomes e água a fim de remover quaisquer resíduos ou placa bacteriana que pudesse interferir no processo de seleção de cor. Concluída a seleção de cor, outros procedimentos como, fotografias iniciais, anestesia local apropriada e isolamento absoluto do campo operatório foram realizados. $\mathrm{O}$ isolamento absoluto foi utilizado em todos os casos, com o emprego de grampos retratores gengivais $n^{-} 212$, reduzindo a contaminação e aumentando a visibilidade do operador, facilitando desta forma os procedimentos operatórios.

As lesões cervicais não foram submetidas a qualquer tipo de preparo cavitário, no que diz respeito àdeterminação de paredes e/ou retenções mecânicas adicionais, e nenhum tratamento foi executado ao longo do ângulo cavosuperficial e, somente quando necessário, recortadores de margem gengival eram empregados para a remoção de prismas de esmalte friáveis. É interessante salientar que com a finalidade de padronização, todos os procedimentos restauradores foram executados por um único operador.

Concluídos esses procedimentos, as lesões cervicais estavam aptas a receber o tratamento restaurador com os materiais em estudo. 


\subsubsection{Sistema Restaurador Adesivo}

O tratamento realizado nos substratos dentários limitou-se à execução do condicionamento ácido do esmalte e da dentina, com o ácido fosfórico a $37 \%$ na forma de gel (total etch - Vivadent), por um tempo de 30 segundos. Decorrido este tempo, as lesões foram lavadas abundantemente com jatos de água por um tempo igual ao do condicionamento, qual seja 30 segundos. A superfície dentária foi seca com o jato de ar posicionado àdistância com o objetivo de não desidratar demasiadamente a dentina e possibilitar o emprego da técnica úmida. Para tanto, as superfícies dentinária e adamantina deveriam estar ligeiramente umedecidas, mas sem excessos de água para possibilitar a penetração do sistema adesivo. A remoção de possíveis excessos de água foi realizada com o emprego de papel absorvente. A aplicação do sistema adesivo monocomponente (Excite Vivadent) foi feita de acordo com as recomendações do fabricante, sendo aplicado com pincéis adaptados, compatíveis com o tamanho da lesão, verificando-se o aspecto brilhoso conseguido, o qual era um indicador da correta aplicação do adesivo. O sistema adesivo foi fotoativado por 20 segundos, utilizando-se um aparelho fotopolimerizador (XL 3000 - 3M), com intensidade de luz de no mínimo $600 \mathrm{~mW} / \mathrm{cm}^{2}$, verificadas no início de cada procedimento ou restauração com 0 auxílio de um radiômetro. Caso não fosse conseguido um aspecto de brilho homogêneo em toda a superfície dentinária, o procedimento adesivo era repetido. A resina composta (Tetric Ceram - Vivadent) foi inserida em três incrementos aplicados consecutivamente nas paredes gengival, incisal/oclusal e cobertura final, com 0 auxílio de espátulas (Thompson - USA) e pincéis. Cada incremento foi fotoativado por 40 segundos.

O acabamento imediato das restaurações foi executado por meio da remoção de eventuais excessos com lâmina de bisturi № 12 , tomando-se 0 cuidado de não induzir defeitos nas margens, enquanto que o acabamento mediato e polimento foram realizados após o período de uma semana, a partir da utilização de brocas multilaminadas de 12 e 30 lâminas (Jet Burs), sob refrigeração, pontas de silicone abrasivas (Enhance - Dentsply), discos abrasivos de granulação fina (SofLex - 3M) aplicados de forma intermitente para evitar a geração de calor excessivo. Todo procedimento de acabamento mediato e polimento foi executado sob 
isolamento relativo com o emprego de rolos de algodão e sugadores de saliva para facilitar o acesso àmargem cervical das lesões o qual ficava limitado quando do emprego dos grampos retratores.

A Tabela 3 descreve as marcas comerciais do sistema restaurador adesivo e do cimento de ionômero de vidro empregados no presente estudo.

TABELA 3- Composição dos materiais e fabricantes

\begin{tabular}{|c|c|c|c|}
\hline MATERIAL & COMPOSIÇÃO & LOTE & FABRICANTE \\
\hline EXCITE & $\begin{array}{l}\text { BIS-GMA, HEMA (2-HIDROXIETILMETACRILATO), } \\
\text { DIMETACRILATOS, ACRILATO DE ÁCIDO FOSFÔNICO, } \\
\text { DIÓXIDO DE SILÍCIO E, INICIADORES E INIBIDORES EM } \\
\text { SOLUÇÃOO ALCOÓLICA (ETANOL) }\end{array}$ & В 20009 & VIVADENT \\
\hline TETRIC-CERAM & $\begin{array}{l}\text { BIS-GMA, DIMETACRILATO DE URETANO E } \\
\text { TRIETILENOGLICOL DIMETACRILATO. VIDRO DE BÁRIO, } \\
\text { TRIFLUORETO DE ITÉRBIO, VIDRO DE FLUORSILICATO } \\
\text { DE ALUMÍNIO E BÁRIO, DIÓXIDO DE SILÍCIO. } \\
\text { CATALISADORES, ESTABILIZADORES E PIGMENTOS }\end{array}$ & B 18241 & VIVADENT \\
\hline $\begin{array}{c}\text { VITREMER } \\
\text { PRIMER }\end{array}$ & $\begin{array}{c}\text { HEMA, ÁCIDO POLICARBOXÍLICO, ÁGUA, ETANOL, } \\
\text { FOTOINICIADOR }\end{array}$ & 19991013 & $3 \mathrm{M}$ \\
\hline VITREMER & $\begin{array}{l}\text { PÓ: VIDRO DE FLUOR-ALUMÍNIO SILICATO } \\
\text { LíQUIDO: HEMA, ÁGUA, SOLUÇÃO AQUOSA } \\
\text { FOTOSENSÍVEL DE ÁCIDO POIALQUEÔNICO MODIFICADA }\end{array}$ & 19991013 & $3 \mathrm{M}$ \\
\hline
\end{tabular}

\subsubsection{Cimento de lonômero de Vidro Modificado por Resina}

O cimento de ionômero de vidro modificado por resina (Vitremer Primer/Vitremer - 3M) foi empregado de acordo com as orientações do fabricante. O primer foi aplicado com um pincel sobre a superfície da lesão, permanecendo em contato com esta por um período de 30 segundos e fotoativado por 20 segundos, com o mesmo aparelho utilizado para o sistema restaurador adesivo. O cimento de ionômero de vidro foi manipulado, na proporção pó/líquido de $1: 1$, em placa de vidro empregando-se espátula o 24 , por aproximadamente 45 segundos até atingir-se, no final da aglutinação, uma massa de consistência cremosa, com aspecto úmido e brilhante. Após a manipulação, o material foi inserido na lesão com o auxílio da seringa do tipo Centrix e o uso de pontas descartáveis. Todo o procedimento de manipulação e inserção do material foi feito por um único operador, bem como o procedimento restaurador. Antes da fotoativação do material, 
acomodava-se o cimento de ionômero de vidro com o auxílio de espátulas para um melhor assentamento do material, na tentativa de dar uma conformação anatômica mais compatível com a região cervical. A fotoativação do cimento de ionômero de vidro modificado por resina foi realizada por um período de 40 segundos.

A remoção dos excessos mais grosseiros foi realizada com lâminas de bisturi no 12 e aplicourse uma fina camada do agente de superfície (Finnishing Gloss - 3M) que acompanha o conjunto do material restaurador. O acabamento e polimento foram executados àsemelhança das restaurações com o sistema restaurador adesivo.

\subsection{Avaliação Clínica}

\subsubsection{Método Direto}

Para a realização das avaliações clínicas empregou-se uma modificação do método de avaliação utilizado pelo Serviço de Saúde Pública Americano (United States Public Health Service), conhecido como Sistema de avaliação do USPHS, que se baseia na inspeção clínica, utilizando-se sonda exploradora $n^{\circ} 5$ e espelho bucal.

O sistema do USPHS determina a padronização de procedimentos prévios àsua utilização, quais sejam: os materiais a serem testados devem ser colocados nas mesmas condições, ou seja, pelo mesmo profissional, em um mesmo paciente e pelo mesmo período de observação. O desempenho de cada restauração é avaliado independentemente, necessitando-se de dois examinadores para se certificar da consistência da avaliação. Em geral, o grau de concordância entre os avaliadores deve ser de pelo menos $85 \%$, conferidas através de calibrações prévias e, quando existe desacordo entre os mesmos, em relação aos resultados obtidos, é feita uma discussão para se chegar a um acordo.

Os critérios adotados para a avaliação do desempenho clínico dos materiais em estudo foram: integridade marginal, descoloração da margem cavo-superficial, retenção, sensibilidade pós-operatória, manutenção da forma anatômica (desgaste) e cárie secundária. Para os critérios retenção e sensibilidade foi empregado uma adaptação ao sistema de avaliação do USPHS, 
pois os mesmos não são contemplados pelo sistema. A forma de utilização desses critérios baseia-se em uma decisão bipolar de respostas Sim ou Não e posterior organização dos dados em escala ordinal (Alfa, Bravo, Charlie e Delta). A descrição dos critérios adotados está minuciosamente enumerada na Tabela 4.

TABELA 4- Descrição dos critérios empregados para a avaliação clínica das restaurações

INTEGRIDADE MARGINAL

\begin{tabular}{ll}
\hline Alfa (A) & Não há evidência visual de fratura marginal e a ponta do explorador \\
Bravo (B) & não é aprisionado na interface dente/restauração. \\
& e/ou base não estão expostas nem a restauração apresenta \\
& mobilidade.
\end{tabular}

Charlie (C) O explorador penetra na interface dente/restauração, apresentando dentina e/ou base expostas, mas a restauração não está móvel, fraturada ou perdida.

Delta (D) A restauração apresenta mobilidade ou não mais existe.

\begin{tabular}{ll}
\hline & \multicolumn{1}{c}{ MANUTENÇÃO DA FORMA ANATÔMICA (DESGASTE) } \\
\hline Alfa (A) & $\begin{array}{l}\text { A restauração apresenta continuidade com a forma anatômica do } \\
\text { dente existente, podendo apresentar um ligeiro sobrecontorno. }\end{array}$ \\
Bravo (B) & $\begin{array}{l}\text { A restauração apresenta continuidade com a forma anatômica da } \\
\text { estrutura dentária, apresentando perda de material restaurador sem } \\
\text { exposição de dentina e/ou base. } \\
\text { Charlie (C) }\end{array} \quad \begin{array}{l}\text { Existe perda de material restaurador levando a exposição de } \\
\text { dentina e/ou base. }\end{array}$ \\
\hline
\end{tabular}

\section{DESCOLORAÇÃO DA MARGEM CAVO-SUPERFICIAL}

Alfa $(A) \quad$ Não há evidência visual de descoloração marginal na interface dente/restauração.

Bravo (B) Há evidência visual de descoloração marginal na interface dente/restauração, mas sua penetração não se estende em direção àpolpa.

Charlie (C) Há evidência visual de descoloração marginal na interface dente/restauração, com evidente extensão da penetração em direção àpol pa.

\begin{tabular}{ll}
\hline & \multicolumn{1}{c}{ RETENÇÃo } \\
\hline $\begin{array}{l}\text { Alfa }(\mathrm{A}) \\
\text { Charlie }(\mathrm{C})\end{array}$ & $\begin{array}{l}\text { Presença da restauração } \\
\text { Ausência parcial ou total da restauração }\end{array}$ \\
\hline \multicolumn{1}{c}{ CÁRIE SECUNDÁRIA } \\
\hline Alfa $(\mathrm{A})$ & \multicolumn{1}{c}{ Não há evidência visual de cárie na interface dente/restauração } \\
Charlie $(\mathrm{C})$ & Há evidência visual de cárie na interface dente/restauração \\
\hline & \multicolumn{1}{c}{ SENSIBILIDADE Pós-OPERATóRIA } \\
\hline Alfa $(\mathrm{A})$ & $\begin{array}{l}\text { Ausência de sintomatologia dolorosa a estímulos térmicos e/ou de } \\
\text { percussão. }\end{array}$ \\
Beta $(\mathrm{B})$ & $\begin{array}{l}\text { Presença de sintomatologia dolorosa quando da atuação dos } \\
\text { diferentes estímulos }\end{array}$ \\
Charlie $(\mathrm{C})$ & Presença de sintomatologia espontânea relatada pelo paciente
\end{tabular}


As avaliações clínicas foram conduzidas por dois profissionais, sendo um aluno de pós-graduação e outro, um professor do Departamento de Dentística, Endodontia e Materiais Dentários da Faculdade de Odontologia de Bauru/USP, sem o conhecimento dos materiais empregados e sem o conhecimento dos conceitos de ambos, o que se caracteriza um estudo cego. As avaliações eram feitas independentemente, e, quando havia discordância entre os conceitos, as restaurações eram reavaliadas em conjunto, chegando-se a um consenso, sendo que esta nova avaliação era considerada a definitiva.

A avaliação clínica imediata (Baseline) foi realizada após o polimento das restaurações e os períodos de avaliação subsequentes foram de seis meses, um ano e dois anos, tomando-se como parâmetros os mesmos critérios avaliados inicialmente. Uma ficha individual foi elaborada (Figura 4) para o registro das avaliações diretas dos examinadores nos diferentes períodos de avaliação considerando os aspectos enumerados na Tabela 4. Cada examinador pôde registrar separadamente os dados de seu exame.

\section{EXAMINADOR:}

Data: Paciente:

Dente:

\begin{tabular}{|l|l|l|l|l|}
\hline CRITÉRIOS & A & B & C & D \\
\hline Integridade Marginal & & & & \\
\hline Desgaste & & & & \\
\hline Descoloração Marginal & & & & \\
\hline Retenção & & & & \\
\hline Cárie Secundária & & & & \\
\hline Sensibilidade & & & & \\
\hline
\end{tabular}

FIGURA 4 - Ficha de avaliação 
Concomitantemente æ̀ avaliações pelo método direto foram conduzidas tomadas fotográficas, com aumentos padronizados de 1,5X, utilizandose uma câmera Nikkon Medical e filmes Ektachrome (Asa 64) para diapositivos coloridos. A obtenção de diapositivos permitiu a documentação da condição clínica inicial e nos diferentes períodos de avaliação, podendo auxiliar para definir classificações clínicas dúbias e ainda, para a ilustração do trabalho e, eventualmente servirem como meio para avaliações clínicas indiretas, após serem transformadas em fotografias ou por projeção.

\subsection{Planejamento Estatístico}

Os dados foram analisados estatisticamente através da comparação dos escores obtidos para cada critério entre os grupos experimentais com o teste exato de Fisher ou o teste Qui-quadrado de Pearson. Para a comparação intragrupo foi utilizado o teste de McNemar. O nível de significância adotado para todos os testes foi de $5 \%(p<0,05)$. 


\section{Resultados}

A realização de um estudo clínico dessa natureza apresenta algumas dificuldades, pois envolve o retorno e o acompanhamento de um grande número de pacientes por um prolongado período de tempo. Os índices de retorno dos pacientes encontram-se descritos na Tabela 5. Conforme pode ser analisado todos os pacientes estiveram disponíveis para as avaliações nos períodos (Baseline, 6 meses e 1 ano), obtendo-se um índice de 100\% de retorno, equivalente a trinta pacientes e setenta restaurações. Na última avaliação dois pacientes não compareceram, um por mudança de cidade, devido àtransferência de emprego e outro por óbito. Esse fato reduziu, o índice de retorno em 6,7\% e o número de restaurações avaliadas diminuiu em 4 , pois cada paciente tinha recebido apenas um par de restaurações.

TABELA 5 - Índice de retorno dos pacientes $(\mathrm{N}=30)$, expressos em porcentagem

\begin{tabular}{c|c|c|c|c|}
\hline Retorno & Baseline & 6 Meses & 1 Ano & 2 Anos \\
\hline Grupos I e II & 100 & 100 & 100 & 93,3 \\
\hline
\end{tabular}

A Tabela 6 mostra o número de restaurações avaliadas em cada intervalo de tempo para os dois grupos e as perdas das restaurações quer seja por deslocamento quer seja devido ao não retorno dos pacientes. 
TABELA 6- Número de restaurações avaliadas nos intervalos de tempo em estudo

\begin{tabular}{lccccccc} 
& \multicolumn{2}{c}{$\begin{array}{c}\text { Restaurações } \\
\text { Avaliadas }\end{array}$} & \multicolumn{2}{c}{ Perda da } & \multicolumn{2}{c}{$\begin{array}{c}\text { Perda do } \\
\text { Restauração }\end{array}$} & \multicolumn{2}{c}{ Paciente } \\
GRUPOS & I & II & I & II & I & II \\
Baseline & 35 & 35 & 0 & 0 & 0 & 0 \\
6 Meses & 31 & 35 & 4 & 0 & 0 & 0 \\
1 Ano & 30 & 35 & 1 & 0 & 0 & 0 \\
2 Anos & 26 & 33 & 2 & 0 & 2 & 2
\end{tabular}

Durante o estudo, o número de restaurações avaliadas permaneceu constante para o grupo II (cimento de ionômero de vidro modificado por resina) em quase todos os períodos de tempo, exceto aos dois anos, quando dois pacientes não retornaram e, dessa forma as restaurações não foram avaliadas. Para o grupo I (resina composta) o comportamento foi diferente, pois aos 6 meses quatro restaurações deslocaram-se, seis meses depois uma restauração deslocou-se e no final de dois anos mais quatro restaurações não foram avaliadas, duas por deslocamento e duas por não retorno do paciente.

Os resultados das avaliações clínicas para o grupo I nos diferentes períodos de tempo e os escores recebidos para os critérios avaliados estão descritos, em porcentagem, na Tabela 7. Os critérios são: retenção (R), integridade marginal (IM), descoloração marginal (DM), desgaste (D), cárie secundária (CS) e sensibilidade (S). 
TABELA 7- Resultados das avaliações, em porcentagem, das restaurações de resina composta (Grupo I)

\begin{tabular}{lccccccccccccccc} 
& \multicolumn{3}{c}{} & \multicolumn{1}{c}{ R } & \multicolumn{3}{c}{ IM } & \multicolumn{1}{c}{ DM } & \multicolumn{4}{c}{ D } & \multicolumn{3}{c}{ CS } \\
ESCORE & A & C & A & B & A & B & A & B & C & A & C & A & B \\
Baseline & 100 & 0 & 97,1 & 2,9 & 100 & 0 & 100 & 0 & 0 & 100 & 0 & 91,4 & 8,6 \\
6 Meses & 89 & 11 & 87,1 & 12,9 & 100 & 0 & 81 & 16 & 3 & 100 & 0 & 97 & 3 \\
1 Ano & 86 & 14 & 67 & 33 & 97 & 3 & 80 & 17 & 3 & 100 & 0 & 97 & 3 \\
2 Anos & 79 & 21 & 50 & 50 & 92 & 8 & 69 & 27 & 4 & 100 & 0 & 100 & 0
\end{tabular}

Os resultados das avaliações clínicas para o grupo II estão descritos, em porcentagem, na Tabela 8.

TABELA 8- Resultados das avaliações, em porcentagem, das restaurações de cimento de ionômero de vidro modificado por resina (Grupo II)

\begin{tabular}{|c|c|c|c|c|c|c|c|c|c|c|c|c|c|}
\hline & \multicolumn{2}{|c|}{$\mathbf{R}$} & \multicolumn{2}{|c|}{ IM } & \multicolumn{2}{|c|}{ DM } & \multicolumn{3}{|c|}{ D } & \multicolumn{2}{|l|}{ CS } & \multicolumn{2}{|c|}{ S } \\
\hline $\begin{array}{l}\text { ESCORE } \\
\text { Baseline }\end{array}$ & $\begin{array}{c}A \\
100\end{array}$ & $\begin{array}{l}\text { C } \\
0\end{array}$ & $\begin{array}{c}A \\
100\end{array}$ & $\begin{array}{l}\text { B } \\
0\end{array}$ & $\begin{array}{r}A \\
100\end{array}$ & $\begin{array}{l}\text { B } \\
0\end{array}$ & $\begin{array}{r}A \\
100\end{array}$ & $\begin{array}{l}\text { B } \\
0\end{array}$ & $\begin{array}{c}C_{0} \\
0\end{array}$ & $\begin{array}{c}A \\
100\end{array}$ & $\begin{array}{l}\text { C } \\
0\end{array}$ & $\begin{array}{c}A \\
100\end{array}$ & $\begin{array}{l}\text { B } \\
0\end{array}$ \\
\hline 6 Meses & 100 & 0 & 88,6 & 11,4 & 100 & 0 & 97,1 & 2,9 & 0 & 100 & 0 & 97,1 & 2,9 \\
\hline 1 Ano & 100 & 0 & 77 & 23 & 100 & 0 & 97,1 & 2,9 & 0 & 100 & 0 & 97,1 & 2,9 \\
\hline 2 Anos & 100 & 0 & 60,6 & 39,4 & 97 & 3 & 85 & 15 & 0 & 100 & 0 & 100 & 0 \\
\hline
\end{tabular}

Com a finalidade de determinar se houve diferença estatisticamente significante entre os grupos, os dados foram submetidos ao teste exato de Fisher ou ao teste Qui-quadrado de Pearson $\left(\chi^{2}\right)$ com nível de significância de $5 \%$. Observou-se que houve diferença estatisticamente significante entre os materiais avaliados somente no critério retenção no período de 2 anos. Entretanto, já no período de um ano, para este mesmo critério, a significância estava próxima com $\mathrm{p}=0,053$. As Tabelas $9,10,11$ e 12 mostram respectivamente as comparações 
entre os grupos nos períodos de tempo avaliados (baseline, 6 meses, 1 ano e 2 anos). Os critérios que não foram analisados mostraram coincidência de escores, não necessitando de comparações.

TABELA 9- Comparação entre os materiais no baseline

$\begin{array}{ccc} & \begin{array}{c}\text { Integridade } \\ \text { Marginal }\end{array} & \text { Sensibilidade } \\ \text { Grupo I } & \mathrm{p}=1,00 & \mathrm{p}=0,23 \\ \mathrm{x} & \mathrm{ns} & \mathrm{ns}\end{array}$

Teste exato de Fisher $(p<0,05)$

ns=não significante

TABELA 10- Comparação entre os materiais aos 6 Meses

$\begin{array}{ccccc} & \text { Retenção } & \begin{array}{c}\text { Integridade } \\ \text { Marginal }\end{array} & \text { Desgaste } & \text { Sensibilidade } \\ \text { Grupo I } & \mathrm{p}=\mathbf{0 , 1 1} & \mathrm{p}=1,00 & \mathrm{p}=\mathbf{0 , 0 9} & \mathrm{p}=1,00 \\ \text { X } & \mathrm{ns} & \mathrm{ns} & \mathrm{ns} & \mathrm{ns} \\ \text { Grupo II } & & & & \end{array}$

Teste exato de Fisher $(p<0,05)$

ns=não significante

\# Teste Qui-quadrado de Pearson $(p<0,05)$

TABELA 11- Comparação entre os materiais no período de 1 ano

\begin{tabular}{cccccc|} 
& Retenção & $\begin{array}{c}\text { Integridade } \\
\text { Marginal }\end{array}$ & $\begin{array}{c}\text { Descoloração } \\
\text { Marginal }\end{array}$ & Desgaste & Sensibilidade \\
$\begin{array}{c}\text { Grupo I } \\
\text { X }\end{array}$ & $\begin{array}{c}\mathrm{p}=\mathbf{0 , 0 5 3} \\
\text { ns }\end{array}$ & $\begin{array}{c}\mathrm{p}=\mathbf{0 , 4 1} \\
\text { ns }\end{array}$ & $\begin{array}{c}\mathrm{p}=\mathbf{0 , 4 6} \\
\mathrm{ns}\end{array}$ & $\begin{array}{c}\# \\
\mathrm{p}=\mathbf{0 , 0 8} \\
\mathrm{ns}\end{array}$ & $\begin{array}{c}\mathrm{p}=1,00 \\
\mathrm{~ns}\end{array}$ \\
Grupo II & & & & & \\
\hline
\end{tabular}

Teste exato de Fisher $(p<0,05)$

ns=não significante

\# Teste Qui-quadrado de Pearson $(p<0,05)$ 
TABELA 12- Comparação entre os materiais no período de 2 anos

\begin{tabular}{|c|c|c|c|c|}
\hline & Retenção & $\begin{array}{l}\text { Integridade } \\
\text { Marginal }\end{array}$ & $\begin{array}{l}\text { Descoloração } \\
\text { marginal }\end{array}$ & Desgaste \\
\hline $\begin{array}{c}\text { Grupo I } \\
x \\
\text { Grupo II }\end{array}$ & $p=\underset{*}{0,01}$ & $\begin{array}{c}p=0,44 \\
n s\end{array}$ & $\begin{array}{c}p=0,57 \\
n s\end{array}$ & $\begin{array}{c}\# \\
p=2,57 \\
n s\end{array}$ \\
\hline \multicolumn{5}{|c|}{$\begin{array}{l}\text { Teste exato de Fisher }(p<0,05) \\
\text { ns=não significante }\end{array}$} \\
\hline $\begin{array}{l}\text { * diferença } \\
\text { \# Teste Qui- }\end{array}$ & $\begin{array}{l}\text { camente s } \\
\text { do de Pear }\end{array}$ & $\begin{array}{l}\text { ante } \\
><0,05)\end{array}$ & & \\
\hline
\end{tabular}

A comparação intragrupo foi realizada com 0 teste de McNemar com nível de significância de $5 \% \quad(p<0,05)$. As Tabelas 13 e 14 respectivamente mostram os resultados das avaliações intragrupo nos diferentes períodos de tempo para os grupos I e II. O critério cárie secundária não foi avaliado, pois o mesmo permaneceu inalterado durante todo o período de avaliação não havendo o aparecimento de lesões cariosas.

TABELA 13- Comparação dos resultados da resina composta nos períodos de avaliação

\begin{tabular}{|c|c|c|c|c|c|}
\hline GRUPO I & Retenção & $\begin{array}{l}\text { Integridade } \\
\text { Marginal }\end{array}$ & $\begin{array}{c}\text { Descoloração } \\
\text { Marginal }\end{array}$ & Desgaste & Sensibilidade \\
\hline $\begin{array}{l}\text { Baseline } x \\
6 \text { Meses }\end{array}$ & $\begin{array}{c}\chi^{2}=2,25 \\
p=0,13 \\
\text { ns }\end{array}$ & $\begin{array}{c}\chi^{2}=\tilde{1}, 33 \\
p=0,24 \\
\text { ns }\end{array}$ & ns & $\begin{array}{c}\chi^{2}=6 \\
p=0,11 \\
\text { ns }\end{array}$ & $\begin{array}{c}\chi^{2}=0,50 \\
p=0,48 \\
\text { ns }\end{array}$ \\
\hline $\begin{array}{l}\text { Baseline } x \\
1 \text { Ano }\end{array}$ & $\begin{array}{c}\chi^{2}=3,20 \\
p=0,07 \\
\text { ns }\end{array}$ & $\begin{array}{c}\chi^{2}=7,11 \\
p=0,008 \\
*\end{array}$ & $\begin{array}{c}\chi^{2}=0,00 \\
p=1 \\
\text { ns }\end{array}$ & $\begin{array}{c}\chi^{2}=6 \\
p=0,11 \\
\text { ns }\end{array}$ & $\begin{array}{c}\chi^{2}=0,50 \\
p=0,48 \\
\text { ns }\end{array}$ \\
\hline $\begin{array}{l}\text { Baseline } x \\
2 \text { anos }\end{array}$ & $\begin{array}{c}\chi^{2}=5,14 \\
p=0,02 \\
*\end{array}$ & $\begin{array}{c}\chi^{2}=10,08 \\
p=0,002 \\
*\end{array}$ & $\begin{array}{c}\chi^{2}=0,50 \\
p=0,48 \\
\text { ns }\end{array}$ & $\begin{array}{c}\chi^{2}=8 \\
p=0,04 \\
*\end{array}$ & ns \\
\hline
\end{tabular}


Analisando a Tabela 13, pode-se constatar que não houve diferença estatisticamente significante entre os períodos inicial (baseline) e seis meses para todos os critérios avaliados. Na comparação com o período de um ano, houve diferença estatisticamente significante no critério integridade marginal. Entretanto, na comparação do período inicial e dois anos, houve diferença estatisticamente significante para os critérios retenção, integridade marginal e desgaste.

TABELA 14- Comparação dos resultados do cimento de ionômero de vidro modificado por resina nos períodos de avaliação

\begin{tabular}{|c|c|c|c|c|c|}
\hline GRUPO II & Retenção & $\begin{array}{l}\text { Integridade } \\
\text { Marginal }\end{array}$ & $\begin{array}{l}\text { Descoloração } \\
\text { Marginal }\end{array}$ & Desgaste & Sensibilidade \\
\hline $\begin{array}{l}\text { Baseline } x \\
6 \text { Meses }\end{array}$ & ns & $\begin{array}{c}\chi^{2}=2,25 \\
p=0,13 \\
\text { ns }\end{array}$ & ns & $\begin{array}{c}\chi^{2}=0,00 \\
p=1 \\
\text { ns }\end{array}$ & $\begin{array}{c}\chi^{2}=0,00 \\
p=1 \\
\text { ns }\end{array}$ \\
\hline $\begin{array}{l}\text { Baseline } x \\
1 \text { Ano }\end{array}$ & ns & $\begin{array}{c}\chi^{2}=6,13 \\
p=0,01 \\
*\end{array}$ & ns & $\begin{array}{c}\chi^{2}=0,00 \\
p=1 \\
\text { ns }\end{array}$ & $\begin{array}{c}\chi^{2}=0,00 \\
p=1 \\
\text { ns }\end{array}$ \\
\hline $\begin{array}{l}\text { Baseline } x \\
2 \text { anos }\end{array}$ & ns & $\begin{array}{c}\chi^{2}=11,08 \\
p=0,001 \\
*\end{array}$ & $\begin{array}{c}\chi^{2}=0,00 \\
p=1 \\
\text { ns }\end{array}$ & $\begin{array}{c}\chi^{2}=3,20 \\
p=0,07 \\
\text { ns }\end{array}$ & ns \\
\hline
\end{tabular}

A análise da Tabela 14 nos permite afirmar que só houve diferença estatisticamente significante no critério integridade marginal quando da comparação do período inicial com os períodos de um ano e dois anos. Os demais critérios permaneceram semelhantes no decorrer do tempo.

Os dois materiais apresentaram comportamento clínico satisfatório no período de dois anos. Na comparação entre os grupos só houve diferença estatisticamente significante no critério retenção, no período de dois anos, conforme análise da Tabela 12. Nos demais critérios os materiais não apresentaram diferenças estatisticamente significante. Nota-se, entretanto, uma superioridade de performance clínica do grupo II, devido àconstância dos escores nos diversos períodos de avaliação. 
As Figuras 5-9 ilustram uma seqüência de acompanhamento da resina composta nos períodos de avaliação (baseline, 6 meses, 1 ano e 2 anos).

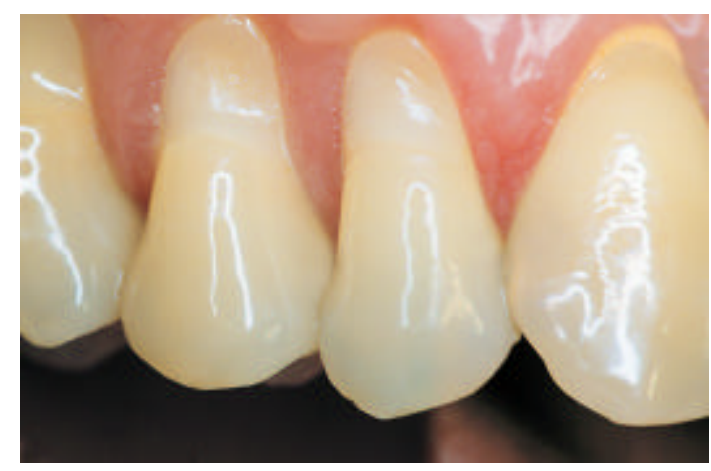

Figura 5 - Lesão cervical no dente 14

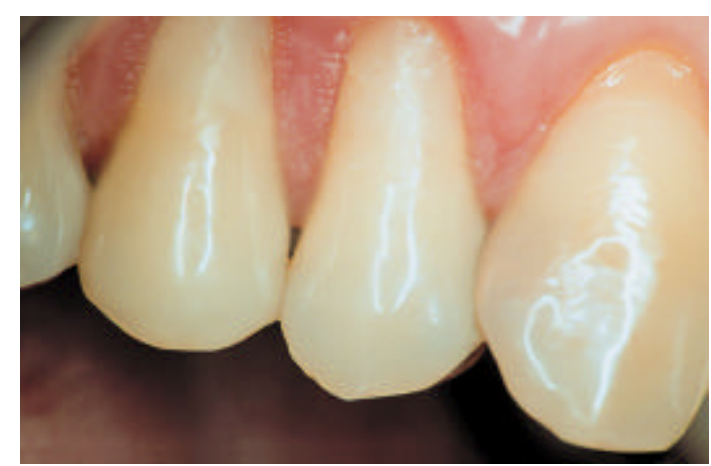

Figura 7 - Aspecto da restauração aos 6 meses

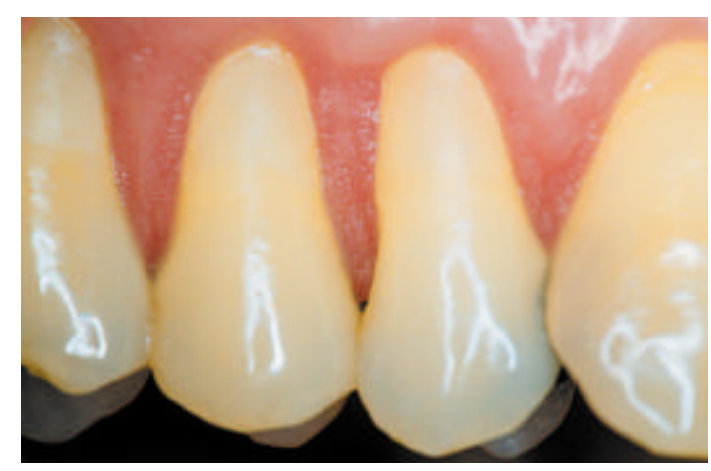

Figura 6 - Aspecto da restauração no baseline

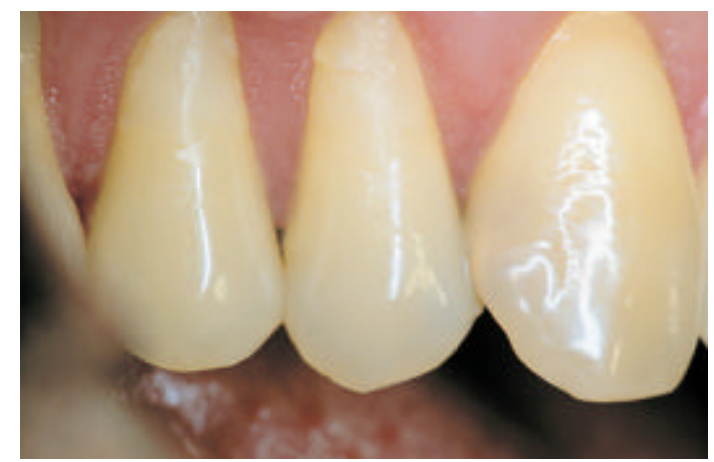

Figura 8 - Aspecto da restauração aos 12 meses

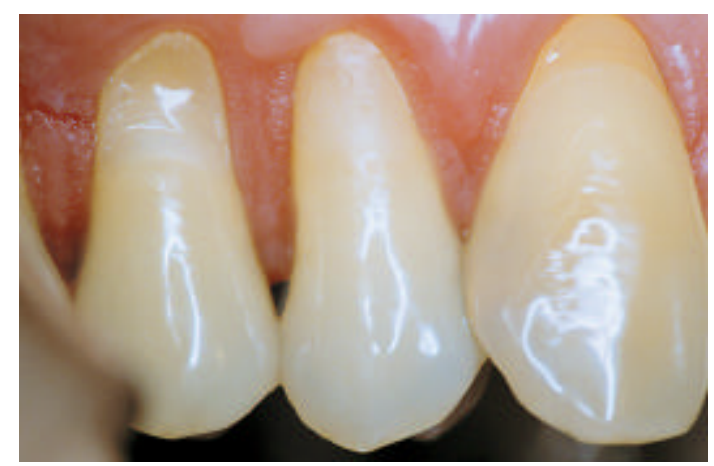

Figura 9 - Aspecto da restauração aos 2 anos 
As Figuras 10-14 ilustram uma seqüência de acompanhamento do cimento de ionômero de vidro modificado por resina composta nos períodos de avaliação (baseline, 6 meses, 1 ano e 2 anos).

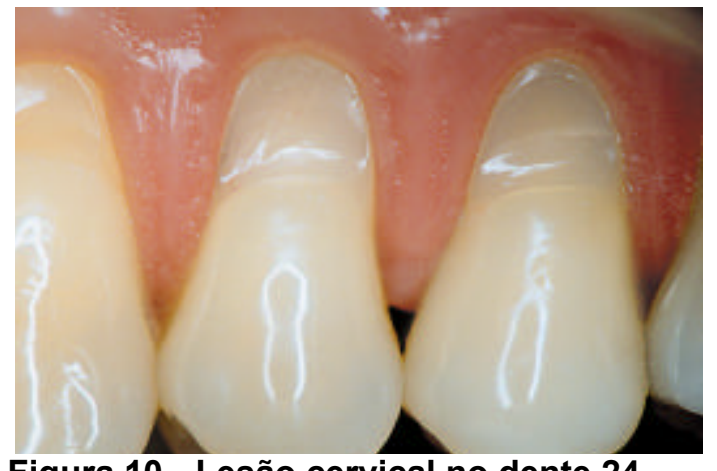

Figura 10 - Lesão cervical no dente 24

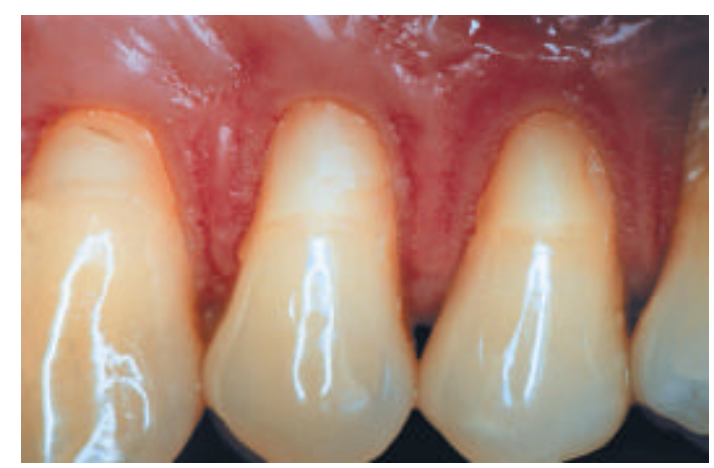

Figura 12- Aspecto da restauração aos 6 meses

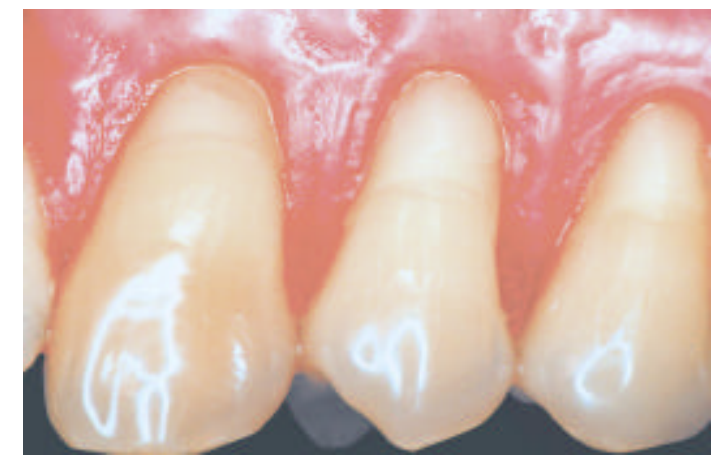

Figura 11 - Aspecto da restauração no baseline

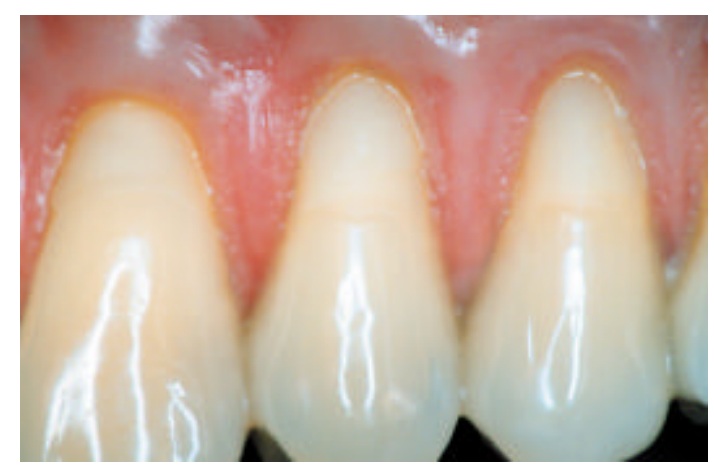

Figura 13 - Aspecto da restauração aos 12 meses

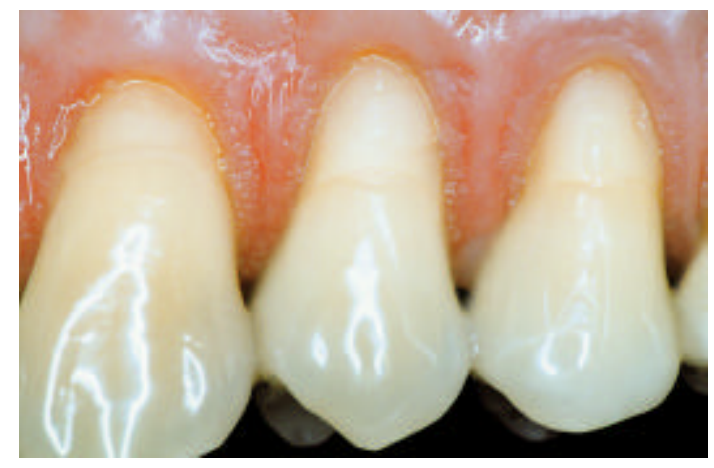

Figura 14- Aspecto da restauração aos 2 anos 


\section{DISCUSSÃo}

\subsection{Da Metodologia}

Durante muitos anos, o tratamento odontológico foi dividido em restauração de dentes anteriores e de dentes posteriores e, para tanto, qualquer material empregado na cavidade bucal, fosse restaurador ou intermediário, necessitava apenas apresentar boas características mecânicas. Com o passar do tempo esse conceito foi ampliado, pois além de boas propriedades mecânicas, os materiais necessitavam apresentar compatibilidade biológica, uma vez que são empregados sobre uma estrutura vital.

Anteriormente àmplantação do programa de especificações da Associação Dentária Americana, a cavidade bucal era usada para testes indeterminados com materiais restauradores. Como os métodos de avaliação utilizados naquela época eram limitadamente controlados, os resultados não eram conclusivos. A análise e os testes laboratoriais são essenciais antes que o material seja utilizado na boca e, infelizmente, a concordância dos dados obtidos e o nível de desempenho clínico são pequenos ou não existe ${ }^{63,68,93,132}$.

No que concerne aos testes laboratoriais, pode-se dizer que não seria tão difícil estabelecermos uma padronização mundial, o que em parte já é feito através das normas ou critérios estabelecidos pela Associação Dentária Americana (ADA). O Conselho de Materiais Dentários, Instrumentos e Equipamentos da ADA desenvolve e divulga especificações e padrões para inúmeros materiais dentários e dispositivos. Após a avaliação destes, o produto passa a ser classificado como: aceitável, aceitável provisoriamente ou não aceitável. A classificação de aceitável é válida normalmente por três anos podendo, ao fim desse período, ser reconsiderada. Os produtos que recebem a classificação de aceitável provisoriamente mostram a existência de evidências razoáveis de sua segurança e utilidade, sendo revistos anualmente durante três anos. A classificação de não 
aceitáveis é dada aos produtos que não passaram pelos critérios da especificação ou que se mostram perigosos àsaúde do clínico ou do paciente ${ }^{4,6,33,68,92}$.

Quanto aos testes clínicos e, mais especificamente, quanto ao acompanhamento do comportamento clínico dos materiais, observa-se que primeiramente as avaliações clínicas eram baseadas em critérios meramente empíricos, o que dificultava grandemente sua reprodutibilidade, comprometendo sua confiabilidade. Atualmente, existem vários métodos de avaliação, na sua grande maioria bem criteriosos; todavia verifica-se, também, uma grande variabilidade na aplicação desses métodos de avaliação, o que muitas vezes torna difícil estabelecermos uma análise comparativa dos resultados apresentados nas diversas pesquisas clínicas ${ }^{63,93,94}$.

Recentemente, houve um grande aumento no número de publicações de avaliação de materiais restauradores. Infelizmente, poucas publicações avaliam a reprodutibilidade ou a sensibilidade do método utilizado. Os estudos que se preocupam com esses fatores afirmam que os métodos de avaliação subjetivos e descritivos apresentam limitações significantes em seus resultados. Dessa forma, verificou-se a necessidade de padronização dos métodos de avaliação, através da introdução de critérios preestabelecidos ${ }^{4,63,93,94,100}$.

O sistema do USPHS, que ainda é utilizado amplamente hoje em dia, determina a padronização de procedimentos prévios a sua utilização quais sejam: os materiais a serem testados devem ser colocados nas mesmas condições, ou seja, pelo mesmo profissional, em um mesmo paciente e pelo mesmo período de observação. O desempenho de cada restauração é avaliado independentemente, necessitando-se de dois examinadores para se certificar da consistência da avaliação. Em geral, o grau de concordância entre os avaliadores deve ser de pelo menos $85 \%$ e, quando existe desacordo entre os mesmos em relação aos resultados obtidos, é feita uma discussão para se chegar a um acordo 4,10,27,63,68,92,94,95,100. 
A avaliação clínica através do sistema do USPHS baseia-se na inspeção clínica, a partir do exame visual, utilizando-se sonda exploradora e espelho bucal, podendo ser empregado tanto para restaurações metálicas quanto para restaurações estéticas ${ }^{10,33,63,94,132}$. A forma de utilização desses critérios baseiase em uma decisão bipolar de respostas Sim ou Não e posterior organização dos dados em escala ordinal (Alfa, Bravo, Charlie e Delta). De acordo com RYGE ${ }^{94}$, esses critérios e conseqüentes classificações refletem uma significância clínica em vez de uma significância estatística. Algumas regras devem ser seguidas para a classificação no sistema: dois profissionais fazem avaliações independentes; cada profissional deve avaliar cada critério; a característica que recebe a classificação mais baixa determina a categoria; se há concordância entre os profissionais, quanto àclassificação, esta é considerada final; se há discordância na classificação, os profissionais devem examinar novamente e juntos chegarem a uma decisão final ${ }^{47,94}$.

Algumas modificações foram acrescidas ao sistema do USPHS a fim de se analisarem características clínicas não abordadas inicialmente. A introdução desses novos critérios determinou o sistema de avaliação USPHS modificado, que além de contemplar os critérios descritos no referido sistema, como integridade marginal, perda da forma anatômica (desgaste), reincidência de cárie, reprodução da cor e descoloração da margem cavo-superficial, avalia também a sensibilidade pós-operatória, retenção e resistência àratura ${ }^{63,68}$.

Outro método direto para a avaliação clínica de restaurações foi estabelecido pela California Dental Association (CDA). Os critérios de avaliação foram elaborados com o objetivo de que a qualidade de trabalho executado pelos cirurgiões-dentistas, abrangendo várias especialidades da Odontologia, fosse avaliada por profissionais clínicos e não por burocratas. As características mais comumente avaliadas com relação à qualidade das restaurações são: textura superficial, cor, forma anatômica e integridade marginal ${ }^{47,94}$. 
O sistema de classificação CDA apresenta duas categorias principais (satisfatória e não aceitável) que, em outras palavras, significam se as restaurações devem ser mantidas ou substituídas. A classificação satisfatória inclui duas subcategorias, sendo a primeira o nível de excelência, no qual a restauração apresenta expectativa de longa durabilidade, protegendo o dente e estruturas circunvizinhas, e a segunda o nível de aceitabilidade, apresentando um ou mais aspectos que a distanciam das condições ideais. As restaurações classificadas como não aceitáveis também podem ser subdivididas em duas subcategorias: substituição por prevenção de danos futuros aos dentes ou tecidos circunvizinhos e substituição imediata, quando esses danos já estão presentes ${ }^{47,95}$.

Diferentemente do sistema USPHS, os códigos empregados por esse sistema não são o Alfa, Bravo, Charlie e Delta (ABCD), para evitar qualquer confusão com sistemas de gradação utilizados em instituições educacionais. Os códigos Romeo, Sierra, Tango e Victor (RSTV) foram preferidos por ser o alfabeto internacional empregado na aviação ${ }^{10,47}$.

Dentre os métodos de avaliação clínica desenvolvidos e de ampla aplicabilidade, o método direto talvez seja o de mais fácil execução e o que apresenta o menor custo operacional. Por outro lado, é dentre todos os métodos de avaliação clínica o mais sujeito a falhas. Desse modo, o método direto tem sido amplamente associado a métodos indiretos a fim de se obter uma análise mais precisa e, principalmente, documentada, uma vez que apenas os métodos indiretos permitem a reavaliação da amostragem depois de determinado período de tempo ou uma posterior discussão entre examinadores ou avaliadores ${ }^{34,63,100}$.

Os métodos indiretos baseiam-se na análise de condições do desempenho clínico dos materiais, através do auxílio de fotografias, réplicas ou qualquer outro tipo de artifício que duplique e/ou reproduza as restaurações dentárias. Assim, de acordo com ERICKSEN ${ }^{34}$, um método de avaliação clínica indireto é definido como uma técnica de registro que reproduz uma condição intrabucal, tornando-a disponível para uma inspeção extrabucal. 
A utilização dos métodos indiretos para a avaliação clínica de materiais restauradores (avaliação por modelos e fotografias) apresenta como vantagens a obtenção de dados quantitativos, o que possibilita a realização de testes estatísticos paramétricos, maior sensibilidade e acurácia. Além disso, permite a documentação da condição clínica nos diferentes períodos de tempo e sua posterior reavaliação. Em contrapartida, constituem-se de métodos cujo custo é mais elevado, necessitando de maior tempo para sua execução e avaliação, e também apresentam uma característica subjetiva ${ }^{34,63,100}$.

ERICKSEN $^{34}$ afirma que a obtenção de diapositivos e ainda de fotografias coloridas, em papel ou transparências, são também sugeridas para a avaliação do desempenho clínico de materiais restauradores estéticos, permitindo análise de critérios como manchamento, descoloração marginal, reincidência de cáries e retenção. Salienta ainda que ambos os métodos de avaliação (direto e indireto) são necessários para a obtenção de uma visão completa e balanceada das propriedades clínicas dos materiais restauradores. Entretanto, JOKSTAD et al. ${ }^{63}$, em uma extensa revisão bibliográfica acerca dos sistemas de avaliação de restaurações, afirmam que os métodos diretos e indiretos de avaliação da qualidade das restaurações detêm-se em características específicas das restaurações mais do que no seu estado geral. Os métodos de avaliação indiretos mascaram a avaliação global da restauração, devendo-se dar preferência a avaliações clínicas diretas, que se tornarão subjetivas ou objetivas dependendo dos critérios específicos estabelecidos. Já a $A D A^{5}$, em 1996, afirma que os métodos de avaliação indiretos como a utilização de fotografias, imagens digitais, modelos de gesso ou réplicas em resina epóxica facilitam a avaliação de mudanças no decorrer do tempo, devendo ser empregados conjuntamente com o método de avaliação direto.

De acordo com a Academia Dentária Americana ${ }^{4}$, as escalas de avaliações e os procedimentos de classificação são recomendados para a avaliação clínica de materiais restauradores. O sistema de apresentar ao pesquisador uma série de decisões bipolares, baseadas em respostas de sim ou 
não, apresenta-se bastante efetivo em estudos clínicos.

Com base na consideração de todas essas variáveis, o presente estudo optou pelo uso do método direto, através do sistema do USPHS modificado, e associação com diapositivos. Esse fato permitiu uma forma mais realística para a comparação das hipóteses estabelecidas, sendo atualmente o método de eleição pela maioria dos pesquisadores da área clínica-restauradora. $A$ obtenção de diapositivos possibilitou a documentação da condição clínica inicial e nos diferentes períodos de avaliação, auxiliando para que fossem definidas classificações clínicas dúbias.

O correto delineamento de um estudo clínico passa por determinadas fases que devem ser respeitadas para que se obtenha um melhor aproveitamento dos dados e, dessa forma, garante a consistência do estudo. JACOBSEN $^{62}$ afirma que experimentos bem delineados aumentam a objetividade do estudo, reduzindo as interferências criadas pelo operador ou pacientes, permitindo um melhor detalhamento das características do material. A Federação Dentária Internacional $^{35}$ (FDI) preconiza inúmeros requisitos que devem ser levados em consideração para o sucesso de um estudo clínico bem conduzido. Entretanto, devese salientar que essas diretrizes podem, aliás, devem ser modificadas para adequação a determinados tipos de estudos e, algumas vezes, deve-se suprimir alguns passos que resultam desnecessários para um estudo clínico específico.

A primeira etapa a ser planejada deve ser a identificação do problema a ser pesquisado, através de um embasamento literário para que o estudo tenha um bom suporte. As hipóteses a serem testadas e os objetivos a serem cumpridos na metodologia devem estar contemplados de maneira elucidativa ${ }^{35}$.

O presente estudo teve como objetivo avaliar o desempenho clínico de materiais restauradores estéticos na restauração de lesões cervicais não cariosas e, como pode ser notado pela literatura levantada, constitui-se um assunto de relevada importância pelos pesquisadores, devido ao grande número de 
publicações encontradas. Até o presente momento, existem muitas controvérsias a respeito de vários fatores que cercam a etiologia, o diagnóstico e o tratamento das lesões cervicais não cariosas. Por meio desta pesquisa tentou-se dar uma contribuição a mais no intuito de elucidar alguns aspectos concernentes ao assunto. Procurou-se, também, seguir as recomendações de órgãos reconhecidamente competentes e com experiência em pesquisa clínica como a Federação Dentária Internacional, a Academia Dentária Americana e a Faculdade de Odontologia de Bauru, através do cumprimento de suas diretrizes, desde a questão da elaboração do projeto de pesquisa como também de sua condução, passando pela determinação da amostragem, aspectos éticos, tipos de testes estatísticos, dentre outros aspectos relevantes.

A hipótese levantada foi a de que ambos os materiais, sistema adesivo/resina composta e cimento de ionômero de vidro modificado por resina, apresentariam comportamentos clínicos semelhantes nos aspectos avaliados e dentro do período de tempo estipulado pelo estudo. Como pode ser notado, é uma hipótese de igualdade sem a especificidade de dizer qual material seria melhor que outro e em que aspecto determinado material seria superior.

Para a determinação da amostragem seguiu-se as orientações da FDI, que enfatiza a importância da cooperação das pessoas e organizações envolvidas, bem como a seleção de pacientes que possuam estabilidade geográfica e que estejam profundamente motivados na participação do estudo até àconclusão ${ }^{35}$. JACOBSEN ${ }^{62}$, além de afirmar que os pacientes devem participar do estudo voluntariamente, estar disponíveis nos períodos de avaliação e também motivados a participar, apresenta os critérios de inclusão do estudo como boa higiene oral, cavidades pequenas ou moderadas, ausência de contatos prematuros, baixo índice de cárie, dentre outros aspectos.

Seguindo essas orientações, a população do estudo constituiu-se de pacientes oriundos da clínica de pós-graduação da Faculdade de Odontologia de Bauru e da Polícia Militar. A escolha da amostragem foi feita de 
forma criteriosa, passando por um processo de triagem, por meio da seleção inicial de pacientes com presença de no mínimo duas lesões cervicais não cariosas e, finalmente, por uma seleção mais criteriosa, baseada na anamnese e exames clínicos e radiográficos. A Federação Dentária Internacional ${ }^{35}$ afirma que a metodologia deve ser bem delineada e consistir de critérios de seleção e exclusão dos pacientes, definindo a população participante; possíveis fontes de pacientes participantes podem incluir escolas, instituições e grupos organizados tais como bombeiros e policiais. Os critérios para inclusão dos pacientes neste estudo foram: adequada higiene oral, baixo índice de cárie, ausência de doença periodontal e hábitos parafuncionais, os dentes deveriam apresentar lesões cervicais não cariosas com profundidades iguais ou superiores a $1 \mathrm{~mm}$, de etiologias diversas, independentemente de sua localização na arcada dentária. Preferencialmente, os dentes selecionados eram hígidos ou portadores de restaurações satisfatórias, sem presença de inflamação gengival ou alterações periapicais e em oclusão.

Avaliados por estes critérios, os paciente só eram incluídos no estudo após serem informados acerca do trabalho, através da orientação do tipo de tratamento a ser executado, do material empregado, e da assinatura do termo de consentimento livre e esclarecido, seguindo as orientações do Comitê de Ética em Pesquisa da FOB-USP60.

O número de pacientes e o número de restaurações constituem-se aspectos de relevada importância para consubstanciar os resultados obtidos através do planejamento estatístico compatível com o modelo experimental. De acordo com JACOBSEN ${ }^{62}$ e RYGE; CVAR $^{93}$ as restaurações devem ser realizadas aos pares, onde um preparo receberá o material a ser testado e o outro deve ser restaurado com o material controle. Os experimentos não pariados, em que cada paciente recebe um material (teste ou controle), são mais fáceis de serem conduzidos sendo, entretanto, mais difíceis de serem analisados, necessitando-se de uma amostragem maior e uma menor variabilidade de condições (tamanho da cavidade, posição do dente, exposição a cargas). A ADA 4 afirma que estudos pariados minimizam os efeitos da diferença entre os indivíduos. Dessa forma, 
seguiu-se a orientação da ADA optando-se por um modelo pariado devido ذ̀ vantagens relatadas e a superioridade em relação a um estudo não pariado.

A Associação Dentária Americana ${ }^{5}$ afirma que o número de indivíduos participantes não pode ser menor que 25 pacientes e que o número de restaurações deve ser de, no mínimo, trinta, sendo que não se pode realizar mais que três restaurações num mesmo indivíduo. Dessa forma, a amostragem, na presente pesquisa, envolveu trinta pacientes e trinta e cinco restaurações por material, um número superior ao recomendado pela ADA e em consonância com a grande maioria dos estudos clínicos consultados, assim como não se realizou mais do que três restaurações por indivíduo, pois uma possível perda de pacientes com maior número de restaurações poderia comprometer a amostragem do estudo.

A $\operatorname{ADA}^{5}$ acrescenta que deve-se apresentar uma distribuição equivalente entre as faixas etárias dos pacientes e um número igual de pacientes em relação ao gênero. No que diz respeito àdistribuição de faixas etárias, a amostragem foi na sua grande maioria de adultos jovens, com média de 39 anos; entretanto, em relação ao gênero, o número de homens foi maior que o número de mulheres, e isto pode ser explicado pela maior prevalência das lesões cervicais não cariosas em pessoas do gênero masculino.

No presente estudo os procedimentos restauradores foram executados por um único profissional com o objetivo de padronização da variável operador. Entretanto, muitos estudos utilizam mais de um operador, os quais devem estar devidamente calibrados para obtenção de resultados satisfatórios. JOKSTAD et al. ${ }^{63}$ afirmam que na realização de estudos clínicos muitas vezes são escolhidos operadores experientes para a confecção dos procedimentos operatórios, sendo relegada a segundo plano a influência do operador na obtenção dos resultados.

O isolamento absoluto do campo operatório foi procedimento adotado em todos os casos, seguindo as orientações estabelecidas previamente no protocolo com vista a evitar a contaminação da superfície dentinária pela umidade 
e/ou sangue, uma vez que as lesões cervicais encontravam-se situadas ao nível ou ligeiramente subgengivalmente, o que permitiria a contaminação da superfície dentinária adjacente, caso fosse empregado 0 isolamento relativo. $\mathrm{O}$ isolamento absoluto evitou a contaminação e aumentou a visibilidade do operador facilitando, dessa forma, os procedimentos operatórios.

A literatura revisada aponta estudos que compararam o comportamento clínico de restaurações empregando tanto 0 isolamento absoluto $^{1,28,29,39,46,54,55,74,87,117,122}$ quanto $\quad 0 \quad$ isolamento relativo $^{12,14,15,16,18,19,20,22,23,51,58,61,73,80,81,104,105,109,112,115,133}$. Os estudos que empregavam o isolamento relativo relatavam que este era feito de forma criteriosa com o emprego de rolos de algodão, fios retratores, suctores de saliva, dentre outros dispositivos. A grande maioria dos autores que optou pelo uso do isolamento relativo afirmou que a escolha desse tipo de isolamento deveu-se ao fato de se tentar chegar o mais próximo possível das condições que o clínico generalista trabalha ${ }^{12,58,61,73,80,81,109,115}$. Entretanto, LIEBENBERG ${ }^{69}$ é enfático ao defender a escolha do isolamento absoluto ratificando suas inúmeras vantagens como a retração dos tecidos gengivais e o controle de variáveis que possam vir a prejudicar os procedimentos restauradores, permitindo uma meticulosa realização dos passos requeridos para a aplicação de sistemas restauradores adesivos. Acrescenta ainda que o dique de borracha é indispensável para o controle de infecções cruzadas e deve sempre ser empregado com o objetivo de melhorar a qualidade do atendimento do paciente.

Os dentes envolvidos com as lesões cervicais não foram submetidos a qualquer tipo de preparo cavitário no que diz respeito àdeterminação de paredes e/ou retenções mecânicas adicionais, e nenhum tratamento foi executado ao longo do ângulo cavo-superficial e, somente quando necessário, recortadores de margem gengival eram empregados para a remoção de prismas de esmalte friáveis. Esse procedimento é padrão para a verificação da efetividade dos sistemas adesivos, sendo normatização recomendada pela ADA quando do estudo da retenção de restaurações com sistemas restauradores adesivos de inserção 
direta ${ }^{5}$. Alguns estudos, entretanto, relegam essa recomendação e fazem algum tipo de modificação, quer seja uma asperização da superfície dentinária, ou até mesmo a confecção do biselamento das margens de esmalte. Dessa forma, torna-se difícil a comparação entre resultados de estudos com protocolos de execução distintos, podendo-se superestimar ou subestimar os resultados obtidos pelos materiais restauradores.

As avaliações clínicas foram conduzidas por dois profissionais, sendo um aluno de pós-graduação e outro, um professor do Departamento de Dentística, Endodontia e Materiais Dentários da Faculdade de Odontologia de Bauru/USP, sem o conhecimento dos materiais empregados e dos conceitos estabelecidos por ambos, o que caracteriza um estudo duplo cego. As avaliações foram feitas independentemente e, quando havia discordância entre os conceitos, as restaurações eram reavaliadas em conjunto, chegando-se a um consenso, sendo que essa nova avaliação era considerada a definitiva. ZAVRAS; GYPSON $^{132}$ relatam que a escolha por um estudo cego é de fundamental importância para eliminar determinadas tendências ou induções dos participantes do estudo, avaliadores e/ou pacientes.

A $\mathrm{ADA}^{4}$ relata que a avaliação clínica deve incluir todas as características comumente empregadas para julgar a aceitação clínica de uma determinada restauração. Os critérios adotados para a avaliação da performance clínica dos materiais em estudo foram: retenção, integridade marginal, descoloração da margem cavo-superficial, manutenção da forma anatômica (desgaste), cárie secundária e sensibilidade pós-opertória. 


\subsection{DOS RESULTADOS}

Como salientado no capítulo de Resultados, a realização de um estudo clínico dessa natureza apresenta algumas dificuldades, pois envolve o retorno e o acompanhamento de um grande número de pacientes por um prolongado período de tempo. Entretanto, o índice de retorno dos pacientes foi extremamente elevado, com $100 \%$ de retorno nas três primeiras avaliações e perda de apenas dois pacientes ao final do estudo, resultando num índice de retorno de $93,3 \%$ em dois anos de avaliação clínica. Alguns estudos de avaliação não relatam o índice de retorno e, como pode ser notado, estes resultados foram superiores à maioria dos estudos e está em consonância com as diretrizes da $\mathrm{ADA}^{5}$, que requer um número mínimo de 25 pacientes no baseline, 20 pacientes aos dois anos e 15 pacientes ao término de 4 anos de avaliação.

A obtenção de um elevado índice de retorno deveu-se, em parte, ao convênio de cooperação existente entre a Faculdade de Odontologia de Bauru e a Polícia Militar, pois cerca da metade dos pacientes envolvidos na pesquisa foram oriundos dessa corporação, o que destaca a seleção de grupos organizados, como os policiais, pois constituem excelentes fontes de referência devido ao cumprimento do compromisso firmado. A motivação dos pacientes (policiais ou não) em colaborarem com o estudo, desde o seu início até os períodos finais de avaliação, pode ser justificada também pela participação de grande parte dos pacientes em outras pesquisas de acompanhamento clínico de materiais (restaurações estéticas de dentes anteriores, restaurações estéticas em dentes posteriores de inserção direta e indireta), fato esse que proporcionou um relacionamento amistoso entre os sujeitos envolvidos na pesquisa e uma cordialidade entre pesquisador e pacientes.

Como reportado anteriormente, os critérios adotados para a avaliação da performance clínica dos materiais em estudo foram: retenção, integridade marginal, descoloração da margem cavo-superficial, manutenção da 
forma anatômica (desgaste), sensibilidade pós-operatória e cárie secundária. Para os critérios retenção e sensibilidade foi empregada uma adaptação ao sistema de avaliação do USPHS, pois os mesmos não são contemplados pelo sistema. A forma de utilização desses critérios baseia-se em uma decisão bipolar de respostas Sim ou Não e posterior organização dos dados em escala ordinal (Alfa, Bravo, Charlie e Delta).

Cada um dos critérios avaliados será discutido e tentar-se-á fazer uma comparação com os estudos revistos, desde que apresentem protocolos de realização semelhantes para que o confronto seja realizado entre as pesquisas com uma amostragem sujeita \&̀ mesmas condições.

\subsubsection{RETENÇÃO}

O sucesso das restaurações de lesões cervicais não cariosas é, entre outros fatores, determinado especialmente pela retenção do material restaurador àdentina e sua respectiva adaptação marginal, garantindo o selamento e impedindo a infiltração inerente e suas conseqüências. De acordo com BOGHOSIAN $^{12}$, a retenção das restaurações de lesões cervicais tem-se apresentado como um excelente modelo para avaliar a eficácia clínica dos sistemas adesivos. Esse fato é decorrente de numerosos fatores como a natureza não retentiva das lesões, grandes áreas de dentina exposta e margens limitadas de esmalte e o alto grau de flexão do dente com decomposição de forças que incidem sobre a região cervical.

Devido àconformação normalmente expulsiva das lesões cervicais, a retentividade dessas restaurações está condicionada ao desenvolvimento de uma união forte e estável do material restaurador àdentina. Entretanto, a dentina de lesões cervicais caracteriza-se, muitas vezes, por ser 
esclerótica e de composição estrutural diferente da dentina normal, determinando uma qualidade de união inferior ${ }^{87,131}$.

No presente estudo, as restaurações com cimento de ionômero de vidro modificado por resina composta (Vitremer-3M) apresentaram um índice de retenção de $100 \%$ em todos os períodos de avaliação, ao passo que o sistema restaurador adesivo (Excite/Tetric-Ceram) apresentou um índice de $79 \%$ ao final de dois anos de acompanhamento. A introdução dos ionômeros modificados melhorou algumas das características adversas dos cimentos ionoméricos convencionais e das resinas compostas e, ao mesmo tempo, mantiveram as boas propriedades de ambos os materiais. O termo cimento de ionômero de vidro modificado por resina refere-se aos materiais que reagem por um processo ácidobase e apresentam uma reação complementar fotoativada, através da polimerização dos monômeros HEMA ou bis-GMA. Os materiais que apresentam componentes dos ionômeros, mas não apresentam a reação ácido-base, são chamados de resina composta modificada por poliácidos ou compômero'.

Os cimentos de ionômero de vidro modificados por resina apresentam algumas vantagens em relação aos cimentos convencionais, podendose destacar a menor sensibilidade aos fenômenos de sinérese e embebição, devido a uma reação de presa mais rápida, melhoria das propriedades mecânicas, facilidade de manipulação decorrente do controle do tempo de presa e melhoria da estética proporcionada pela aproximação dos índices de refração do líquido e das partículas de pó do cimento ${ }^{96}$.

Estudos de espectrometria de massa identificaram que 0 mecanismo de adesão dos ionômeros modificados por resina envolve processos de trocas iônicas, com a evidência de movimentação de íons do cimento de ionômero de vidro para a dentina e vice-versa, adesão esta que parece desenvolver-se através da formação de uma camada de trocas iônicas adjacente àdentina, semelhante àque ocorre com os cimentos convencionais ${ }^{70}$. Todavia, o mecanismo de reação de presa e adesão desses materiais apresenta uma estreita correlação 
com seu conteúdo polimérico, especialmente de HEMA, já que a polimerização deste leva a diferentes taxas de desenvolvimento da reação ácido/base, característica e inerente aos mesmos ${ }^{70,98,129}$. O emprego de primers contendo HEMA produz uma aparência interfacial muito semelhante à dos sistemas adesivos, sugerindo a existência de formação de camada híbrida como um mecanismo a mais na união do cimento àestrutura dentária. Entretanto, essa aparência é restrita a uma sólida camada superficial, sem apresentar a infiltração de longos tags no interior dos túbulos dentinários. De acordo com WATSON ${ }^{124}$, o termo camada de absorção tem sido aplicado para designar essa estrutura e parece ter um papel relevante na retenção das restaurações por compensar a contração de polimerização. Dessa forma, pode-se sintetizar que a adesão dos ionômeros híbridos está baseada na interação de dois mecanismos, um oriundo da interação iônica entre estrutura dentária e material restaurador, semelhante ao que ocorre com os cimentos convencionais, e o outro pela camada de absorção, similar àca mada híbrida dos sistemas adesivos.

YAP; NEO ${ }^{129}$ relataram que a adesão do cimento de ionômero de vidro modificado por resina àdentina representa uma grande vantagem sendo, dessa forma, o material de eleição para a restauração de lesões cervicais não cariosas. Esse fato é corroborado por TYAS ${ }^{110}$, em 1995, que após uma revisão da literatura acerca dos materiais e técnicas empregados para a restauração de lesões cervicais concluiu que o cimento de ionômero de vidro representa o melhor material para a restauração desses tipos de lesões devido ao pequeno número de falhas em retenção demonstrado em estudos clínicos.

Resultados semelhantes aos do presente estudo foram obtidos por MANEENUT; TYAS ${ }^{73}$ que realizaram um acompanhamento clínico com restaurações de ionômero de vidro modificado por resina, sendo um deles o Vitremer. Ao final de um ano de avaliação, não houve deslocamento de nenhuma restauração. ABDALLA; ALHADAINY ${ }^{1}$ avaliaram clinicamente três marcas comerciais de cimentos de ionômero de vidro modificado por resina (Fuji II LC, Photac-Fil e Vitremer) e uma resina composta modificada por poliácidos (Dyract). 
Após o período de dois anos, tiveram o índice de 100\% de retenção para o mesmo tipo de ionômero empregado na presente pesquisa. Entretanto, eles concluíram que embora todos os materiais tenham apresentado um excelente comportamento clínico no período de dois anos, um acompanhamento mais longo é requerido para se estabelecer a real longevidade desses materiais.

Com o objetivo de comparar o melhor material para a restauração de lesões cervicais não cariosas, NEO et al. ${ }^{81}$ conduziram um estudo de avaliação clínica com dois cimentos de ionômero de vidro, um de presa química e outro modificado por resina, comparativamente com os sistemas adesivos. Ao final de 18 meses de avaliação, o sistema adesivo Imperva Bond apresentou índice de retenção de $65 \%$, ao passo que o sistema adesivo Prisma Universal Bond 3 e os ionômeros de vidro (químico e modificado por resina) apresentaram índices de retenção de 95 a 100\%. Através da comparação clínica de cimentos de ionômero de vidro convencional e modificado por resina, GLADYS et al. ${ }^{46}$ obtiveram índices de retenção de $100 \%$ ao final de 18 meses para o Vitremer e o Fuji II LC e um índice semelhante $(97 \%)$ para o cimento de ionômero convencional, podendo-se deduzir que os dois materiais apresentam-se efetivos para a restauração de lesões cervicais devido ao baixo índice de falhas.

Como pode ser observado, o cimento de ionômero de vidro modificado por resina apresentou excelentes resultados de retenção neste trabalho (100\%) e em muitos dos trabalhos de avaliação clínica apresentados, com índices de retenção variando de 90 a 100\%1,14,15,16,39,40,41,46,116. Esses dados podem ser indicadores da melhoria das propriedades do referido cimento com uma união à estrutura dentária mais eficiente ${ }^{129}$ e menor módulo de elasticidade quando comparados aos cimentos convencionais, possibilitando a ocorrência de deformações elásticas sem, entretanto, ocorrer o deslocamento da restauração quando sujeita àflexão dentária ${ }^{98}$. 
Numa avaliação clínica de 10 anos, MATIS; COCHRAN; $\mathrm{CARLSON}^{74}$ verificaram que os cimentos ionoméricos convencionais apresentaram índices de retenção estatisticamente maiores que a resina composta e concluíram que o cimento de ionômero de vidro é o material ideal para restauração de lesões de erosão/abrasão cervicais quando um procedimento não invasivo for recomendado, devido ao alto índice de retenção por longos períodos de tempo. Os autores enfatizaram que nenhum material restaurador, com possível exceção para o ouro em folha, apresentou excelentes resultados de retenção por um período tão prolongado, em lesões cervicais, e esse fato pode ser explicado devido àunião química existente entre o material restaurador e à estrutura dentária. Entretanto, vale ressaltar que essa diferença estatística entre o ionômero de vidro e a resina composta pode ser atribuída também pelo fato de o sistema adesivo, disponível na época da realização do estudo, apresentar baixos valores de união àdentina.

O sistema adesivo empregado para a restauração das lesões cervicais (Excite/Vivadent) apresenta um emprego caracterizado por fases distintas de condicionamento superficial da dentina com uma solução de ácido fosfórico a $37 \%$ e posterior aplicação de uma solução única de monômeros resinosos contendo primer e adesivo. Especificamente, o condicionamento ácido remove os componentes minerais e expõe fibras colágenas. A dentina peritubular desaparece na porção mais superficial dos túbulos, abrindo sua embocadura e conferindo a estes uma forma afunilada. Devido àremoção da porção mineral da dentina intertubular, ficam expostas as fibras colágenas e o espaço anteriormente ocupado pelo mineral é ocupado pela água oriunda da lavagem do ácido e da permeabilidade dentinária. Para que o mecanismo de adesão se processe satisfatoriamente, é preciso que os monômeros resinosos penetrem por entre os espaços interfibrilares, substituindo a água ali presente. De fato, as fibras colágenas desprovidas de seu componente mineral apresentam um baixo módulo de elasticidade e só são mantidas em uma condição expandida devido àpresença de água $^{25,86}$. Para que os monômeros resinosos possam se infiltrar, substituindo a água, é necessário que esta seja removida. É nesse momento que a água desempenha um papel fundamental no mecanismo de união dos sistemas adesivos 
para a formação da camada híbrida. As instruções do uso do sistema Excite ressaltam a importância da manutenção da umidade superficial antes da aplicação do agente resinoso. Atentos a esse fato, realizou-se uma secagem de superfície com o auxílio de papel absorvente, objetivando a remoção do excesso de água sem desidratação superficial. A desidratação da dentina desmineralizada com jatos de ar poderia causar uma contração e conseqüente colapso das fibras colágenas sobre a dentina subjacente, reduzindo os espaços interfibrilares de difusão do agente adesivo $^{25}$. O adesivo Excite é um sistema a base de álcool, sendo que esse solvente orgânico exerce a função de desidratar a trama de fibras colágenas quimicamente, substituindo a água pela resina que infiltra simultaneamente nos espaços entre as fibras. Após a polimerização do sistema, forma-se uma nova camada composta de fibras colágenas e monômeros resinosos, denominada de camada híbrida. Aceitase, atualmente, que este seja o principal e mais eficiente mecanismo de adesão à dentina $99,106,121$.

Na presente pesquisa, o sistema adesivo monocomponente (Excite - Vivadent) apresentou um índice de retenção inferior ao cimento ionomérico. Os índices foram de $100 \%$ no baseline, $89 \%$ aos 6 meses, $86 \%$ aos 12 meses e $79 \%$ aos dois anos. Entretanto, os valores só apresentaram diferença estatisticamente significante aos dois anos. O maior número de deslocamento de restaurações neste grupo, totalizando 4 (58\%), ocorreu nos seis primeiros meses do estudo e, decorridos mais seis meses, houve o deslocamento de uma restauração (14\%) e no final do estudo mais duas restaurações deslocaram-se (28\%). Esse fator é corroborado por HEYMANN et al. ${ }^{55}$, que apresentou 39 restaurações deslocadas de um total de 178 ao final de dois anos de avaliação. Analisando a fase em que ocorreu o maior número de deslocamento de restaurações, os autores observaram que 22 restaurações (56\%) deslocaram-se nos seis primeiros meses de vida clínica. Esse fato pode ser um indicador de que o índice de falhas dos sistemas adesivos ocorre nos períodos iniciais de vida clínica e mantém-se, de certa forma, mais estabilizado com o passar do tempo. 
De forma semelhante, POWELL; GORDON; JOHNSON ${ }^{87}$ observaram retenção de $97,3 \%$ para o ionômero convencional (Ketac-Fil) e de $75,7 \%$ para o sistema adesivo Scothbond 2 ao final de três anos. Os autores inferiram que o baixo índice apresentado pelo grupo envolvendo sistema adesivo e resina composta pode estar diretamente relacionado ao substrato, uma vez que os pacientes apresentavam, em média, 70 anos de idade, ou seja, com maior presença de dentina esclerótica. Autores como NEO; CHEW, empregando uma amostragem e metodologia semelhantes a da presente pesquisa, apresentaram resultados muito coincidentes com índices de retenção de 78\% para o sistema adesivo (Scothbond dual cure) e 95\% para o ionômero convencional (Ketac-Fil). Salientaram que as falhas de adesão para o sistema adesivo são multifatoriais e podem incluir presença de dentina esclerótica, localização da lesão, tamanho e formato da lesão, variável operador, lote do fabricante e fatores oclusais.

Mesmo conscientes de que esses sistemas adesivos relatados acima pertençam a uma geração anterior ao utilizado na presente pesquisa, apresentando mecanismo de ação diferente e resistência adesiva inferior, vale ressaltar que o acompanhamento clínico de restauração de lesões cervicais com o emprego de sistemas adesivos de última geração apresenta resultados diversos, com índices de retenção variando de 51 a $100 \%{ }^{12,19,20,22,39,40,72,104,105,113,116,120}$ levando a crer que embora esses materiais apresentem uma satisfatória união com o substrato dentinário, representada pela formação da camada híbrida, os fatores responsáveis pelo fracasso dos sistemas restauradores adesivos predecessores continuam presentes e interferindo na longevidade das restaurações cervicais com os sistemas adesivos mais recentes.

Dentre esses fatores interferentes, a qualidade do substrato dentinário, relacionada com o tipo de dentina e a idade do paciente, merece algumas considerações. As lesões cervicais não cariosas estão expostas ao ambiente bucal por um prolongado período de tempo, podendo passar por mudanças estruturais em função de alterações intra-orais, como fluxo e composição salivar, higiene oral, nutrição e estresse oclusal ${ }^{50,54}$. A idade é outro fator que altera gradativamente a 
composição e a estrutura da dentina. Os túbulos dentinários apresentam-se obstruídos pela deposição de dentina peritubular ou pela precipitação de cálcio no interior dos túbulos. Todos os tipos de obliteração são dependentes do tempo de ação do agente causador e as mudanças graduais refletem na histoquímica da dentina $^{79}$. A precipitação de minerais no interior dos túbulos dentinários tem sido reportada como uma resposta de pequenas agressões como cárie, abrasão, erosão, abfração e o aumento da idade. As alterações decorrentes de todos esses fenômenos, resultando num aumento do conteúdo mineral da dentina, são coletivamente denominadas de esclerose dentinária ${ }^{79,102}$.

A grande maioria dos estudos laboratoriais realizados com sistemas adesivos emprega como substrato de adesão a dentina normal, sem, contudo, levar em consideração substratos clinicamente encontrados com maior freqüência na prática clínica, como a dentina afetada por cárie e a dentina cervical esclerótica ${ }^{86}$. Num estudo conduzido por Yoshiama et al. ${ }^{131}$, avaliou-se a resistência adesiva por meio do teste de microtração, em espécimes oriundos da mesma região, e com substratos em condições diferentes, apresentando dentina normal, afetada por cárie e dentina esclerótica. Os resultados desse estudo revelaram que os substratos afetados por cárie e com dentina esclerótica apresentaram resistências adesivas $30 \%$ inferiores ao substrato normal. Os autores explicaram que esse fato pode ser devido à presença de esclerose dentinária presente em ambos os substratos, a qual oblitera os túbulos dentinários, diminuindo a permeabilidade dentinária e conseqüente formação de $\operatorname{tags}^{86,131}$.

HEYMANN et al. ${ }^{54}$ e HEYMANN et al. ${ }^{55}$, relataram que a esclerose dentinária associada àidade do paciente pode explicar o grande número de falhas de restaurações de lesões cervicais com o sistema restaurador adesivo em pacientes mais velhos. Já van DIJKEN ${ }^{116}$, em 2000, observou que um número igual de restaurações apresentou falhas para lesões escleróticas e não escleróticas, concluindo que não ficou confirmada a interação negativa entre esclerose dentinária e retenção clínica dos sistemas adesivos, o que reforça a observação anterior de que o processo de adesão envolve aspectos multifatoriais. Não obstante esse 
posicionamento, a literatura tem apresentado diferentes entendimentos relacionados àretenção de restaurações cervicais em função da idade do pa ciente e do tipo de dentina, sendo que BAYNE et al. ${ }^{9}$ relataram que o resultado mais interessante do seu estudo foi a correlação efetiva existente entre as falhas de retenção em pacientes mais velhos. Os pacientes de 21-40, 41-60 e 61-80 tiveram perdas na retenção de, respectivamente, $31 \%, 62 \%$ e $75 \%$. Entretanto, van DIJKEN ${ }^{115}$, em 1994 e TYAS $^{111}$, em 1996, analisaram a influência das três faixas etárias no índice de retenção e não encontraram associação entre ambas. Não se pode negar a ocorrência de modificações estruturais do esmalte e da dentina decorrentes do avanço da idade e a possível correlação existente entre essas alterações e a longevidade das restaurações cervicais, mas também não se pode creditar os insucessos de retenção unicamente em função do tipo de substrato.

No corrente estudo não se verificou uma associação entre o índice de retenção e o fator idade ou esclerose dentinária. No que diz respeito à idade, a faixa etária que participou da pesquisa foi de 23 a 68 anos, com 16 pacientes na faixa de 20 a 39 anos, 13 pacientes entre 40 a 49 anos e apenas 1 paciente com mais de 60 anos. Portanto, não se pôde verificar a influência desse fator no índice de retenção, pois necessitar-se-ia de um número igual de pacientes nos três grupos etários ${ }^{5}$. Em relação àesclerose dentinária, apenas uma lesão que teve falha de retenção apresentou uma esclerose dentinária típica com coloração escurecida em mais de $50 \%$ da superfície dentinária. Verifica-se, entretanto, que a superfície das lesões cervicais pode apresentar alterações na estrutura e composição dentinária, sem apresentar sinais clínicos de esclerose.

Assim, outros fatores devem ser considerados dentre os responsáveis pelas falhas das restaurações de lesões cervicais. No que diz respeito àoclusão, HEYMANN et al. ${ }^{54}$, em 1988, relataram que dos treze pacientes que apresentaram falhas, doze tinham algum tipo de fator interferente (facetas, bruxismo e/ou apertamento), tendo apresentado associação estatisticamente significante. Os autores concluíram que, embora não tenha havido diferença estatisticamente significante para os critérios e combinações avaliadas, os fatores de oclusão 
traumática e idade do paciente ou combinação de ambos parecem estar envolvidos no índice de falhas das restaurações.

A teoria da flexão dentária proposta por LEE; EAKLE ${ }^{66}$ desenvolveu a hipótese do possível papel das tensões de tração no surgimento das lesões cervicais não cariosas. Para os autores, o fator etiológico primário é o estresse oclusal causado pela mastigação e má oclusão. Fatores locais, como escovação ou ácidos, saliva e hiperatividade muscular desempenham um papel coadjuvante na perda de estrutura dentária.

As lesões causadas por forças oclusais excêntricas ou exageradas são denominadas de abfração e resultam da ruptura dos cristais de esmalte por tensões de tração e compressão, tornando a região mais susceptível à abrasão e erosão. As lesões de abfração apresentam-se em forma de cunha, são profundas e têm margens definidas, podendo ser encontradas em apenas um dente ${ }^{44,48,49,50,65,66,71}$. De acordo com GALIEN; KAPLAN; OWENS ${ }^{44}$ e LEE; EAKLE ${ }^{67}$, essas peculiares lesões em $\mathrm{V}$ ou em forma de cunha são localizadas em áreas de má-oclusão e em áreas onde abrasão por escovação são improváveis, como por exemplo, sob a margem gengival livre ou superfícies proximais, e raramente encontradas em superfícies linguais ${ }^{71}$. Outra particularidade desse fenômeno é a ocorrência de lesões em apenas um único dente do arco, enquanto os adjacentes permanecem hígidos.

As lesões oriundas de forças oclusais excêntricas apresentam as seguintes características: localização próxima ao fulcro do dente e morfologia típica em forma de cunha, representativa do volume de maior concentração de tensões nessa região. $O$ formato pode ser modificado por fatores locais, mas o padrão geral deve ser em forma de cunha com ângulos nítidos. A direção das forças laterais geradas pela tensão de tração determina a localização da lesão. E, por último, o tamanho da lesão está diretamente relacionado com a magnitude e freqüência de aplicação das forças que geram a tensão de tração na região cervical ${ }^{66}$. 
A flexão dentária tem sido reportada como uma das principais causas contribuintes para as falhas de retenção dos sistemas adesivos em restaurações cervicais ${ }^{56,129}$. O mecanismo de ação da flexão dentária pode ser explicado por dois eventos distintos: a deformação lateral do dente causada por forças oclusais durante os movimentos da mastigação na presença de oclusão normal, resultando em tensões de tração nas margens das restaurações cervicais; e a deformação vertical do dente causada por forças de contato exageradas, como no bruxismo e oclusão traumática, resultando em tensões de compressão com deslocamento da restauração cervical.

Como em todas as áreas da Odontologia, o correto diagnóstico deve preceder a realização do tratamento ${ }^{65,128}$. A determinação do fator etiológico das lesões cervicais não cariosas parece relativamente insignificante; entretanto, as forças que atuaram sobre o esmalte e deram início àformação das lesões continuarão a atuar sobre a restauração. Dessa forma, as forças oclusais devem ser consideradas como um fator etiológico na formação das lesões cervicais, bem como na falha de restaurações cervicais por meio de um diagnóstico acurado ${ }^{65}$.

LEE; EAKLE ${ }^{67}$, em 1996, afirmam que a perda prematura de restauração de lesões cervicais ocorre quando a oclusão não é correta, pois as restaurações estão sujeitas s̀ forças de tração que podem causar a desadaptação da restauração, infiltração e falhas de retenção.

Embora conscientes da teoria da flexão dentária como fator desencadeante inicial na formação das lesões cervicais não cariosas e, possivelmente responsável pelo índice de falhas de restaurações cervicais, acreditase que esse fator não tenha sido influente, primariamente, no índice de falhas do presente estudo. Nenhum paciente selecionado apresentava bruxismo e/ou facetas de desgaste visíveis clinicamente, pois isso se caracterizava num dos critérios de exclusão para participação no estudo. Entretanto, a associação da teoria da flexão dentária com os diferentes comportamentos dos materiais, quando submetidos estes 
a cargas, devido propriedades biomecânicas distintas, podem ter resultado num maior índice de falhas para o sistema adesivo que para o cimento de ionômero de vidro.

Para HANAOKA et al. $^{50}$, os materiais restauradores empregados na região cervical são constantemente atingidos por resultantes de forças que atuam na superfície oclusal, devendo apresentar características biomecânicas aceitáveis para resistir ̀̀ tensões. Um aspecto importante a ser considerado quando da eleição de um material restaurador para lesões cervicais relaciona-se àcaracterística do material em absorver parte das tensões geradas durante a aplicação de cargas. O módulo de elasticidade é uma propriedade de relevada importância na retenção das restaurações de lesões cervicais não cariosas. Estudos de avaliação clínica têm demonstrado maior número de falhas de retenção associadas a materiais com maior conteúdo de carga, como as resinas compostas híbridas $^{54,55,129}$.

HEYMANN et al. $^{54}$, em 1988, utilizaram duas resinas compostas com diferentes módulos de elasticidade e observaram que as resinas de macropartículas apresentaram maior número de falhas (17) do que as resinas de micropartículas (10). Entretanto, não houve diferenças estatísticas significantes entre os grupos e sim uma diferença numérica. De acordo com HEYMANN et al. ${ }^{55}$, em 1991, o achado mais interessante do estudo foi a relação existente entre o índice de falhas e o módulo de elasticidade dos materiais empregados. As resinas de macropartículas apresentaram maior número de falhas que as de micropartículas, e isso pode ser explicado devido ao maior conteúdo de matriz orgânica das micropartículas e conseqüente menor módulo de elasticidade, permitindo uma deformação elástica em vez de deslocamento durante a flexão dentária. Essa opinião é corroborada por BAYNE et al. ${ }^{9}$ que afirmaram que os materiais restauradores de menor módulo de elasticidade apresentam melhor desempenho que os de maior módulo, pois durante a flexão dentária eles apresentam uma deformação elástica, não ocorrendo a fratura ou deslocamento do material. Quando um material mais rígido é empregado, como as resinas compostas híbridas, as 
tensões geradas na interface adesiva podem exceder as tensões de compressão e gerar falhas de adesão entre a estrutura dentária e o sistema adesivo ${ }^{129}$. Comparando-se o módulo de elasticidade do cimento de ionômero de vidro com a resina composta, verifica-se uma menor rigidez para o ionômero, fato esse correlacionado ao contingente orgânico e as reações inerentes ao material.

Por outro lado, a literatura não apresenta consenso quanto ao papel do módulo de elasticidade no sucesso clínico de restaurações de lesões cervicais não cariosas. BROWNING; BRACKETT; GILPATRICK ${ }^{19,20}$, avaliaram o desempenho de uma resina de micropartícula e uma resina híbrida após um ano de avaliação, obtendo um índice de retenção de $97 \%$ para ambos os materiais. Ao final de dois anos de avaliação, tiveram um índice de retenção, respectivamente para as resinas de micropartículas e híbrida, de $89 \%$ e $86 \%$, os quais não apresentaram diferenças estatísticas significantes. Dessa forma, questionaram a relevância do módulo de elasticidade dos materiais na retenção de restauração de lesões cervicais não cariosas. BURROW; TYAS ${ }^{23}$, em 1999, avaliaram o índice de retenção nesses tipos de lesões empregando um sistema adesivo de frasco único associados a materiais de diferentes módulos de elasticidade. Os materiais empregados foram duas resinas de baixo módulo de elasticidade (AEliteflow e Bisco Glaze) e a resina de micropartícula (Silux Plus), todos empregados com o sistema adesivo One-Step. Os autores concluíram que os novos sistemas restauradores adesivos empregando adesivos que formam a camada híbrida têm uma performance clínica satisfatória e que não houve diferença entre as resinas de baixo módulo de elasticidade e a resina de micropartícula no que diz respeito àretenção das restaurações. Não obstante as controvérsias observadas na literatura, deve-se salientar novamente que um fator não pode ser considerado isoladamente, mas sim como um elemento coadjuvante e inter-relacionado com os demais fatores analisados.

Uma explicação plausível para os bons resultados apresentados pelo cimento de ionômero de vidro, no presente estudo, é que esse material possibilita um maior relaxamento das tensões geradas quando da contração de polimerização e menores alterações térmicas subseqüentes ${ }^{87}$, associando-se, 
ainda, a diferença entre o módulo de elasticidade dos materiais empregados, minimizando o efeito desses fenômenos em relação ̀̀ forças que atuam na região cervical dos dentes. Esse fato é ratificado por YAP; NEO ${ }^{129}$ que observaram maiores falhas de retenção em materiais com maior módulo de elasticidade, e concluíram que essa propriedade deve ter uma importância relevante quando do estudo da retenção de restaurações em lesões cervicais não cariosas.

A preocupação com baixos valores de retenção para 0 sistema adesivo de frasco único tem sido apresentado na literatura. van DIJKEN observou índices variáveis de retenção, sendo que ao final de 3 anos o sistema adesivo de passo único (One-Step) estabeleceu 51\% de efetividade de retenção, contrastando com o sistema adesivo de três passos (EBS) e o cimento de ionômero de vidro modificado por resina com $90 \%$ e $93 \%$ de retenção respectivamente. 0 autor relatou a dificuldade de obtenção de superfície de dentina brilhante, quando do emprego do adesivo de frasco único, e considerou a maior sensibilidade técnica quando da utilização de adesivos simplificados, pois para muitos dos sistemas é difícil volatizar o solvente sem remover uma grande quantidade de adesivo e, dessa forma, diminuindo a espessura da camada híbrida formada. A diferença de resultados entre os dois sistemas adesivos empregados pode estar relacionada com a dificuldade no diagnóstico da esclerose dentinária, indução de efeitos relacionados àflexão dentária, tempo de aplicação e acidez do condicionador empregado e a sensibilidade técnica.

FOLWACZNY et al. ${ }^{39}$, em 2000, observaram resultados que diferem dos apresentados no presente estudo. Empregando o sistema Syntac/Tetric, obtiveram $100 \%$ de retenção ao final de dois anos e, para os ionômeros modificados por resina, um índice de 90 a 94\%. Embora não tenha havido diferenças estatísticas entre os materiais, vale ressaltar que os tipos cavitários empregados foram diversos, com lesões de etiologia cariosa e não cariosa e substituição de restauração, associando-se o acabamento do ângulo cavo-superficial na forma de bisel para as restaurações de resina composta, podendo ser esse o motivo para o elevado índice de retenção para a resina composta. 
O acabamento do ângulo cavo-superficial na forma de bisel tem por objetivo expor os prismas de esmalte transversalmente, mascarar a linha de união dente/restauração, aumentar a área de união e expor uma superfície mais reativa pelo aumento da energia de superfície. Convém ressaltar que esse procedimento, bem como a confecção de retenções mecânicas adicionais, não foram realizados para as restaurações de resina composta devido ànormatização da ADA como explicado anteriormente na discussão da metodologia. É necessário relatar que a qualidade e quantidade do esmalte nas margens cervicais de lesões cariosas é atípica, pois muitas vezes está ausente e, quando existente, apresenta-se em pequena espessura e aprismático. Entretanto, as margens oclusais apresentam esmalte em maior quantidade e qualidade que poderiam, quando adequadamente tratados, ter um papel fundamental no desempenho satisfatório das restaurações cervicais. Tanto que, em condições clínicas normais, o procedimento de tratamento mecânico das margens do preparo e a confecção de retenções mecânicas adicionais são rotineiramente recomendados quando da execução de restaurações de lesões cervicais. Portanto, para o presente estudo, a não-realização do tratamento mecânico do ângulo cavo-superficial nas restaurações realizadas com sistema restaurador adesivo pode ter influenciado no número de falhas apresentado pelo referido grupo.

BAYNE et al. ${ }^{9}$ destacam que o aumento da área de união, pela confecção do bisel, principalmente em lesões de pequena profundidade, é de fundamental importância. Em lesões rasas, aumentando-se a área disponível para união, expande-se a dissipação de estresses, que estavam concentrados na interface, favorecendo em maior grau a retenção. Adicionalmente, tem-se, com o aumento da extensão em esmalte, uma maior e efetiva união do que a dentinária, sendo que quando da flexão dentária decorrente das forças oclusais os dois tecidos comportam-se de maneira diferente. OSBORNE-SMITH; BURKE; WILSON ${ }^{83}$ afirmaram que a realização do bisel e retenções mecânicas adicionais podem alterar a distribuição dos estresses internos nas restaurações cervicais e melhorar a estabilidade do material na cavidade. VANHARLE et al. ${ }^{122}$ corroboram a opinião em 
relação đ̀ retenções mecânicas adicionais e enfatizam a necessidade de asperização do substrato dentinário com brocas para uma melhor união dos sistemas adesivos e a estrutura dentária. Acrescenta ainda que a execução de retenções mecânicas adicionais é necessária para a estabilização do material no caso de lesões cervicais. Com relação àefetividade da asperização da superfície dentinária na melhoria da união entre material restaurador e estrutura dentária, não é confirmado por van DIJKEN ${ }^{116}$, que comparou esse procedimento com um grupo controle onde nenhuma modificação foi realizada na superfície dentinária de lesões cervicais escleróticas. O resultado obtido pelo autor foi de que no grupo em que se realizou a asperização houve maior número de falhas de retenção que no grupo não asperizado, relacionando o fato ànão -remoção de toda dentina esclerótica quando da asperização e, conseqüentemente, pela não-exposição de uma camada de dentina mais reativa para a formação da camada híbrida.

No trabalho de revisão conduzido por BRACKETT; ROBINSON ${ }^{13}$ foi apresentado que o prognóstico para retenção em lesões cervicais sem preparo cavitário é crítico, na presença de estresse oclusal, com o aumento da idade do paciente e quando as lesões são de pequena espessura. Esses achados são confirmados pelo estudo de BRANDAU; ZIEMIECKI; CHARBENEAU ${ }^{18}$, pois observaram que a perda das restaurações $(25 \%)$ parece estar associada com a pequena profundidade da lesão nas extremidades mesial e distal do defeito cervical e não com a angulação e o tipo de defeito cervical. De forma complementar, ZIEMIECKI; DENINSON; CHARBENEAU ${ }^{133}$ relataram que as características das lesões, nas restaurações que falharam, são as seguintes: a maior parte das lesões era de forma circular, com ângulo maior que $135^{\circ}$ e com dimensões inciso-cervicais menores que $2 \mathrm{~mm}$ e profundidade de $1 \mathrm{~mm}$. HEYMANN et al. ${ }^{55}$ afirmam que 0 formato da lesão é crucial porque altera a distribuição dos estresses na interface dente/restauração. Eles relatam que as lesões em forma de cunha produzem tensões de tração e compressão que podem deslocar a restauração durante a flexão do dente. HEYMANN; BAYNE ${ }^{56}$, em 1993, afirmaram que as lesões em forma de cunha, com angulação menor que $135^{\circ}$ entre as paredes cervical e incisal, são mais retentivas que as lesões de forma circular com angulação maior que $135^{\circ}$. 
Acrescentam ainda que as lesões de forma circular e de pequena profundidade não permitem a inserção de quantidade suficiente de material restaurador que possa resistir àdeflexão e podem ser mais vulneráveis ao deslocamento durante a flexão dentária em função ou para-função. Dessa forma, pode-se inferir que as dimensões da lesão (profundidade e largura inciso-cervical) são mais importantes do que o formato da lesão quando da análise do índice de retenção das restaurações cervicais. Essa afirmação é compartilhada por NEO; $\mathrm{CHEW}^{80}$ os quais relataram que a área de superfície disponível para união é um dos fatores responsáveis pelas falhas de retenção, pois em seu trabalho muitas das restaurações que falharam eram oriundas de lesões diminutas em extensão e profundidade. Esse fator foi observado no presente estudo, pois das sete restaurações deslocadas, três apresentavam pequena profundidade nas extremidades mesial e distal do defeito cervical.

No que diz respeito àlocalização da lesão, alguns estudos relatam uma maior predominância de falhas nos dentes inferiores ${ }^{51,54,55,56,80,87,133}$, provavelmente por apresentarem maior flexão devido àinclinaçã o lingual da coroa clínica dos dentes inferiores e ao menor diâmetro em relação aos dentes superiores, fazendo com que haja menor resistência àresultante das forças que atuam na região cervical. Outro fator relaciona-se àmaior dificuldade de se conseguir 0 controle da umidade na região mandibular, tornando o isolamento mais crítico, isto quando se considera a utilização do isolamento relativo do campo operatório. Esse aspecto não foi observado no presente estudo, pois não houve diferença no índice de falhas quando se analisa a localização das restaurações. Na região da maxila, das 26 restaurações executadas, cinco deslocaram-se $(19,2 \%)$ e, na região da mandíbula, das 9 restaurações realizadas, houve deslocamento de duas $(22,2 \%)$. 0 fato de se ter maior número de restaurações na maxila pode ser explicado pela maior prevalência das lesões cervicais nos pré-molares superiores, caninos e primeiros molares superiores. 
Analisando as falhas observadas na pesquisa em questão, sete ocorreram em restaurações executadas com o sistema adesivo e nenhuma falha em restaurações com o cimento de ionômero de vidro. Uma tentativa de explicar a maior ocorrência de falhas de retenção para o sistema adesivo é que, haja além da dinâmica de união entre estrutura dentária e material restaurador, uma associação de fatores que incluem o dente (localização no arco, tipo de dentina, formato da lesão), o material (módulo de elasticidade e mecanismo de união) e o paciente (idade e oclusão) inter-relacionados na contribuição das falhas de retenção. Portanto, deve-se considerar que os fatores contribuintes para as falhas na união dos sistemas adesivos são provavelmente multifatoriais. Assim, mais do que apontar o aspecto mais influente para o sucesso de uma restauração dever-se-iam considerar as limitações dos materiais restauradores adesivos disponíveis e as técnicas envolvidas. Não obstante o maior índice de sucesso das restaurações cervicais, em termos de retenção, as falhas podem ser creditadas aos diferentes fatores envolvidos, não sendo possível apontar um fator mais predominante.

\subsubsection{INTEGRIDADE MARGINAL E DESCOLORAÇÃO MARGINAL}

Alguns fatores estão intimamente associados àadaptação marginal de materiais restauradores, sendo que dentre os que tendem a melhorar a adaptação marginal têm-se a união mecânica da resina composta ao esmalte condicionado e a expansão higroscópica estabelecida pelo material; por outro lado, os que tendem a afetar a adaptação relacionam-se àcontração de polimerização e alterações dimensionais associadas ao coeficiente de expansão térmica. Um fator que concorre diretamente para a existência de fendas marginais envolve a ausência de esmalte ou a presença de prismas de esmalte sem suporte frente à margens cavitárias $^{21}$. 
Para minimizar esse efeito, nas lesões cervicais envolvidas no presente estudo procedeu-se àplanificação das margens cavitárias com o auxílio de recortadores de margens gengivais a fim de se removerem possíveis áreas com prismas de esmalte friáveis, propiciando uma perfeita adaptação da restauração ao dente, no intuito de não comprometer a integridade marginal.

Os resultados obtidos no estudo para esses critérios apresentaram comportamentos distintos, entretanto não houve diferenças estatisticamente significantes. Para a integridade marginal, ambos os materiais apresentaram uma degradação significativa com o decorrer do tempo, isso notado pela grande mudança de escores das restaurações de Alfa para Bravo após o primeiro e segundo anos de avaliação. Ao final de dois anos, metade das restaurações de resina apresentou escore Alfa e a outra metade escore Bravo. Para o cimento de ionômero de vidro, cerca de 40\% das restaurações apresentaram escore Bravo. No que diz respeito àdescoloração marginal, o comportamento clínico foi mais satisfatório pois as restaurações de resina composta apresentaram $92 \%$ de escore Alfa e as restaurações de ionômero de vidro 97\%.

De acordo com HEYMANN et al. ${ }^{54}$, em 1988, as pequenas variações na integridade e descoloração marginal no período de um ano de avaliação também não evidenciaram diferenças estatísticas entre as técnicas empregadas. Observações de IANZANO; GWINNETT ${ }^{61}$ apontaram que após um ano de acompanhamento de restaurações com o sistema adesivo All Bond 2 e resina composta Bis-Fil $\mathrm{M}, 83,1 \%$ apresentaram escore Alfa para o critério integridade marginal e 95,8\% para a descoloração marginal, relacionando estas falhas ao sobrecontorno e não por fraturas do material ou do dente, fato esse corroborado por HÖRSTED-BINDSLEV; KNUDSEN; BAELUM ${ }^{58}$, que atribuíram as mudanças de conceitos Alfa para Bravo, quanto ao critério integridade marginal, devido a fraturas decorrentes do sobrecontorno de material restaurador nas margens. 
Para BRANDAU; ZIEMIECKI; CHARBENEAU ${ }^{18}$, a descoloração marginal foi evidente em apenas $9 \%$ das restaurações, resultados esses semelhantes aos obtidos pela presente pesquisa. POWELL; GORDON; JOHNSON ${ }^{87}$ obtiveram um índice de $97 \%$ e $86 \%$ de Alfa para o ionômero e a resina composta, respectivamente, ao final de 3 anos para o critério descoloração marginal. BURROW TYAS ${ }^{23}$ também observaram a presença de um pequeno número de restaurações com descoloração marginal, relacionando o fato pela presença de excesso de material restaurador em áreas não condicionadas e não removidos após o polimento.

Com o objetivo de avaliar o melhor material para a restauração de lesões cervicais não cariosas, NEO et al. ${ }^{81}$, em 1996, conduziram um estudo de avaliação clínica com dois cimentos de ionômero de vidro, sendo um convencional e outro resino-modificado comparativamente com dois sistemas restauradores adesivos. Com relação àdescoloração marginal, todos os materiais exibiram algum tipo de manchamento nas margens, que foi apenas estatisticamente significante para as restaurações com o sistema adesivo que apresentaram $50 \%$ conceito Bravo após 18 meses. Esses resultados foram diferentes pelos obtidos no estudo em questão, em que se obteve 92\% de conceito Alfa ao final de 24 meses. Entretanto, da mesma forma que o presente estudo, NEO et al. ${ }^{81}$ relataram que um número significante de restaurações para os quatro materiais apresentou perda na integridade marginal, passando de Alfa para Bravo aos 18 meses. Segundo os próprios autores, os fatores que contribuíram para a perda da integridade e descoloração marginal dos materiais estudados são a perda contínua da estrutura dentária ou a ocorrência de pequenas fraturas do material nas margens associados aos fatores oclusais, pois as restaurações cervicais sofrem tensões geradas pelas forças oclusais que atuam, possivelmente, como colaboradoras no processo de deterioração das margens.

Os sistemas adesivos e os cimentos de ionômero de vidro modificado por resina apresentaram uma grande melhoria no que diz respeito ao aspecto de união aos substratos dentários. Entretanto, independentemente de 
maiores valores de resistências adesivas, a flexão dentária pode contribuir para a ocorrência de pequenos defeitos marginais localizados, comprometendo a integridade marginal das restaurações cervicais ${ }^{55}$. Quando uma união satisfatória é estabelecida entre material restaurador e estrutura dentária, as forças geradas por compressão da restauração atuam mais no corpo da restauração do que na interface adesiva. Conseqüentemente, a união adesiva é preservada, enquanto que a integridade marginal é afetada ${ }^{120}$.

$\mathrm{Na}$ presente pesquisa, uma possível explicação para a deterioração das margens da restauração e comprometimento da interface pode ser a fratura do material restaurador. Tanto para as restaurações de resina composta como para as realizadas com cimento de ionômero de vidro, embora não tenha sido realizado o acabamento das paredes de esmalte na forma de bisel, a própria configuração da lesão pode ter determinado bordas com diferentes espessuras predispondo, em algumas situações, bordas finas ou que sobrepassaram o ângulo cavo-superficial. Dessa forma, as pequenas fraturas marginais dos materiais restauradores utilizados possivelmente relacionam-se ao pequeno volume de resina composta e cimento de ionômero de vidro na interface dente/restauração. Além disso, fraturas da estrutura dentária, devido àpequena espessura do esmalte na região cervical, pode ter sido, adicionalmente, um dos fatores para 0 estabelecimento de escores Bravo, para a integridade marginal, pois o esmalte cervical mantém a predisposição de friabilidade com vista ষ̀ tensões originadas das forças mastigatórias.

Esses dados são confirmados pelo estudo de PRATI et al. ${ }^{89}$ que analisaram, por microscopia eletrônica de varredura, a qualidade marginal de vários sistemas restauradores adesivos, inclusive a do ionômero Vitremer, observando que a qualidade marginal do esmalte foi grandemente influenciada pelas fraturas de prismas de esmalte, onde em alguns casos os prismas foram removidos e pequenos defeitos na interface eram visíveis. Acrescenta, ainda, que os procedimentos de acabamento e polimento apresentaram-se bastante agressivos à dentina, com margens em dentina mais desgastadas do que a resina composta. De 
um modo geral, as restaurações com ionômero de vidro apresentaram menor fratura de esmalte e menores falhas marginais em dentina que as de resina composta. Os autores concluíram que o completo selamento das margens em dentina ainda está longe do ideal e a presença de discrepâncias marginais sugere que a contração de polimerização, própria dos materiais resinosos, pode criar um prejuízo \&̀ margens das restaurações acarretando num efeito negativo na sobrevida de restaurações de resina composta.

Deve-se considerar que a contração de polimerização gera tensão interna no material resinoso e, ao unir-se s̀ paredes ca vitárias, parte dessa tensão é aliviada pelo escoamento viscoelástico durante a polimerização do material. Assim, a magnitude da tensão gerada na interface de união estará na dependência da contração de polimerização e do alívio estabelecido pela expansão higroscópica da resina composta, decorrente da sorpção de água ${ }^{36}$.

Os problemas na interface dente/restauração como integridade marginal e descoloração marginal estão associados à propriedades físicas e mecânicas dos materiais ${ }^{30}$. A diferença no coeficiente de expansão térmica entre dente e material restaurador induz ao fenômeno de percolação e, conseqüentemente, de alterações marginais. Coeficientes de expansão térmica diferentes entre 0 dente e o material restaurador propiciam, pelas repetidas mudanças de temperatura, tensões nas margens aderidas, as quais somam-se ⿳亠े criadas durante a contração de polimerização, resultando em infiltração e descoloração marginais ${ }^{36,55}$. No presente estudo, os materiais empregados apresentaram comportamentos semelhantes nos aspectos de integridade $e$ descoloração marginal, embora tivessem coeficientes de expansão térmica distintos. O cimento de ionômero de vidro modificado por resina tem um coeficiente de expansão menor que o da resina composta. Entretanto, a explicação para as fendas marginais presentes também no grupo do referido cimento pode ser atribuída ao risco de fratura de esmalte devido àexcelente propriedade adesiva associada com a contração de polimerização ${ }^{98}$. 
Utilizando uma metodologia muito próxima a do presente estudo NEO; $\mathrm{CHEW}^{80}$ observaram que a deterioração marginal foi mais pronunciada do que a descoloração para todos os grupos. Ao final de três anos, os autores concluíram que não houve diferenças estatísticas significantes para os critérios descoloração marginal e adaptação marginal, embora tenha havido uma deterioração geral das restaurações com o passar do tempo, aspecto também observado na presente pesquisa. Os autores afirmaram que a presença de uma grande porcentagem de restaurações com conceito Bravo, no critério integridade marginal, não prejudicou a performance geral das restaurações, pois as mesmas apresentaram-se clinicamente aceitáveis sem necessidade de substituição. Esse fato também foi observado por ABDALLA; ALHADAINY ${ }^{1}$, onde todos os grupos apresentaram discrepâncias marginais e descoloração marginal, entretanto não estatisticamente significantes. Já MANEENUT; TYAS ${ }^{73}$ realizaram um acompanhamento clínico, por um período de um ano, com cimento de ionômero de vidro modificado por resina em lesões cervicais e observaram que, ao término de um ano, todas as restaurações apresentaram um aumento estatisticamente significante na descoloração marginal, descoloração essa clinicamente insignificante.

No trabalho de van MEERBEEK et al. ${ }^{120}$ concluiu-se que embora os índices de retenção tenham melhorado para os sistemas adesivos atuais, o selamento marginal ainda é um problema a ser solucionado. Ressaltaram que a microinfiltração clínica, ao contrário do índice de retenção, pode ser um fator mais efetivo para a avaliação de novos sistemas adesivos, pois embora os materiais apresentassem elevados índices de retenção nenhum deles garantiu margens livres de infiltração marginal e descoloração. GLADYS et al. ${ }^{46}$ avaliando a adaptação marginal de cimentos ionoméricos - convencional e modificado por resina empregados para restauração de lesões cervicais, observaram que, mesmo com elevados índices de retenção, nenhum dos sistemas pode garantir margens livres de microinfiltração por um período de tempo longo. Os autores chegaram àmesma conclusão de van MEERBEEK et al. ${ }^{120}$ de que a adaptação e o selamento marginais continuam sendo um problema, precisam ser melhorados e que as pesquisas futuras deveriam se concentrar na melhoria desses aspectos. 


\subsubsection{MANutenção da Forma ANATÔMica (Desgate)}

A avaliação do desgaste de materiais restauradores em pesquisas clínicas constitui-se em procedimento de alta complexidade pois é dependente de inúmeros fatores. Esse aspecto incorpora elementos multifatoriais, sendo responsável pela grande variação de resultados apresentados na literatura específica $^{63}$. O desgaste pode ser resultante de vários mecanismos que incluem abrasão mecânica, desgaste erosivo, desgaste por fadiga, sendo dependentes do contato com a estrutura dentária, alimentos, escova dentária e dentifrícios ${ }^{98}$. Os materiais restauradores, de uma forma geral, variam em resistência aos diferentes mecanismos de desgaste podendo, também, apresentar um desgaste excessivo em determinado paciente, e em outro completamente ausente ${ }^{63}$.

$\mathrm{Na}$ tentativa de se comparar o melhor método de avaliação da manutenção da forma anatômica de restaurações, CHADWICK et al.$^{26}$ avaliaram, através de dois métodos - clínico e indireto -, o desgaste oclusal de dois materiais (resina composta e cimento ionomérico) tendo o amálgama como controle. Observou-se que o método indireto foi mais eficiente em detectar diferenças entre os materiais, fato que não ocorreu com o método de avaliação clínico. Entretanto, FOLWACZNY et al. ${ }^{38}$, em 2000, realizaram um estudo para verificar as mudanças superficiais ocorridas nas restaurações executadas por um período de três anos, através do emprego de um scanner a laser em três dimensões. Diferentemente do estudo de CHADWICK et al. ${ }^{26}$, os autores concluíram que o emprego do método de avaliação clínica proporcionou resultados semelhantes ao método indireto empregado para a avaliação do desgaste. Entretanto, vale ressaltar que pequenas variações não são percebidas visualmente, sendo requerida a associação de métodos para uma avaliação mais acurada do desgaste de materiais restauradores. 
Como pode ser observado pela análise dos resultados, no critério desgaste não houve diferença estatística entre os materiais. Entretanto, houve uma diferença entre o comportamento dos materiais ao longo do tempo. A resina composta apresentou um maior número de desgaste que o ionômero. Ao final de dois anos, a resina apresentou $69 \%$ de escore Alfa e $27 \%$ de Bravo, com $4 \%$ de escore Charlie - restauração inaceitável. Já o cimento de ionômero de vidro apresentou um desempenho mais uniforme com o passar do tempo, resultando em $85 \%$ de escore Alfa e $15 \%$ Bravo ao final de dois anos. Como os materiais foram distribuídos de forma pariada, o fator variabilidade de paciente não pode ser justificado como causa do maior desgaste, pois ambos os materiais foram empregados nos mesmos pacientes. A possível explicação para o comportamento desfavorável pode ser devido àforça exagerada de escovação, concentrada em apenas uma região, apresentada pelo referido paciente, pois este resultado foi verificado por um único paciente. A escova dentária e abrasivos de cremes dentários podem afetar a superfície de materiais restauradores com perda de substância, principalmente em paciente com lesões de origem abrasivas ${ }^{38}$. Outro fator que pode explicar o comportamento dos dois materiais em relação ao desgaste é que os materiais restauradores empregados na região cervical estão constantemente expostos \$̀ tensões de tração durante a flexão dentária, e essa resultante das forças atua na região cervical sobre os materiais com a formação de trincas no corpo da restauração. A propagação dessas trincas pode resultar numa abfração de parte do material restaurador e pode ser interpretada como desgaste das restaurações ${ }^{39}$.

Com relação aos estudos que avaliaram clinicamente 0 desgaste dos materiais restauradores, podemos observar uma grande variedade de resultados. Os estudos conduzidos por HEYMANN et al. ${ }^{54}$ e DUKE et al. ${ }^{30} \mathrm{com}$ avaliação de um e dois anos respectivamente, reportaram que as restaurações mantiveram a forma anatômica durante o período de avaliação. BRANDAU; ZIEMIECKI; CHARBENEAU ${ }^{18}$, avaliando a performance de cimentos de ionômero convencionais observaram que, em relação à forma anatômica, $80 \%$ das restaurações apresentaram uma continuidade com a estrutura dentária, sendo que $7 \%$ apresentaram subcontorno e $13 \%$ perda de material com exposição dentinária. 
NEO; CHEW $^{80}$ apresentaram resultados diferentes do presente estudo, relatando que embora não tenha havido diferenças estatisticamente significantes para o critério forma anatômica, as restaurações com o cimento de ionômero de vidro exibiram maior mudança, com $77 \%$ das restaurações com conceito Alfa após três anos. FOLWACZNY et al. ${ }^{39,40}$ utilizando a resina composta Tetric, mostraram que o desgaste para este material foi menor do que 0 apresentado pelos ionômeros, e estatisticamente significante, por um período de dois e três anos de acompanhamento. A explicação para a mudança da forma anatômica das restaurações executadas com o ionômero deve-se s̀ propriedad es físicas inferiores, como a resistência ao desgaste associada àforça de escovação excessiva. Já ABDALLA; ALHADAINY ${ }^{1}$ relataram que 100\% das restaurações de Dyract receberam conceito Alfa, 94\% das restaurações de Photac-Fil e Vitremer tiveram conceitos Alfa e 90\% para as restaurações de Fuji II LC. Os autores relataram que esses resultados parecem estar associados à melhoria das propriedades físicas dos ionômeros híbridos.

\subsubsection{CÁRIe SECundÁRIa e SENSIBILIDADE Pós-OPERATóRIA}

O critério cárie secundária, ou melhor dizendo, desenvolvimento de lesão cariosa, permaneceu inalterado durante todo o período do estudo para ambos os materiais. A incorporação do flúor em materiais restauradores tem despertado interesse especial por se constituir em uma fonte potencial de liberação desse elemento em baixas concentrações e em períodos prolongados de tempo. A ação preventiva da liberação de flúor, a partir de materiais restauradores como o cimento de ionômero de vidro convencional, tem encorajado os fabricantes de materiais dentários a promoverem aperfeiçoamentos nesses materiais, assim como a incorporação de flúor, como por exemplo, nas resinas compostas. Os materiais restauradores que liberam flúor podem contribuir para o equilíbrio do $\mathrm{pH}$ crítico bucal, reduzindo os períodos de desmineralização e tornando mais frequentes 
e mais longos os ciclos de remineralização. Outra ação do flúor é evidenciada pelas propriedades antibacteriana e antienzimática, contribuindo na redução do acúmulo de placa sobre a restauração o que reduz o aparecimento de cáries secundárias e estabelece maior longevidade s̀ restaurações ${ }^{45,103}$.

Entretanto, apesar de se saber que a resina composta empregada no presente estudo (Tetric-Ceram) contém flúor na sua composição, a liberação desse elemento químico é desprezível ${ }^{45,130}$. A fonte de liberação de flúor da resina composta está nos componentes da matriz resinosa, como o tri-fluoreto de itérbio, e nas cargas vítreas de flúor alumínio silicato e fluoreto de estrôncio ${ }^{45}$. O cimento de ionômero de vidro modificado por resina apresenta uma liberação de flúor similar àdos cimentos convencionais sendo, entretanto, o mecanismo de liberação diferente devido ao processo de reação de presa ${ }^{98,123}$. Adicionalmente, os cimentos resino-modificados podem funcionar como um sistema de recarregamento de flúor, através da incorporação deste elemento quando da exposição no interior da cavidade bucal, atuando como um depósito de flúor, por meio da lenta liberação por períodos de tempo prolongados ${ }^{98}$. A ocorrência de flúor na cavidade bucal, e mais particularmente o seu contato na interface dente/restauração, é de grande importância para prevenir a desmineralização inicial nas margens cavitárias, podendo aumentar a longevidade dos tratamentos restauradores. Vale ressaltar que o tratamento mais eficaz da doença cárie, além da ação preventiva do flúor, é a complementação conseguida pela adequação dos hábitos alimentares e de higiene associados ao efetivo controle de placa, capazes de equilibrar o meio bucal, ou melhor, atuar na promoção de saúde bucal ${ }^{45}$.

Dessa forma, acredita-se que o não-aparecimento de lesão de cárie no presente estudo deva ser atribuído àmelhoria da higiene bucal e hábito alimentar do paciente, coadjuvados pelos critérios de seleção dos pacientes no estudo os quais, para serem incluídos na amostra, necessitavam de apresentar baixo índice de cárie. Pacientes que participam de pesquisas de acompanhamento clínico, que resultam em maior freqüência àclinica dentária empenham -se mais na higiene bucal. Provavelmente, esse aspecto tenha contribuído para a não- 
observação de lesões cariosas neste estudo, assim como em outras pesquisas clínicas, onde a detecção desse tipo de ocorrência tem se mostrado praticamente nula ou, quando observada, relaciona-se pontualmente em alguns pacientes que demonstram risco à cárie. Portanto, fica evidente que o surgimento de lesões cariosas decorre fundamentalmente do controle do paciente quanto aos fatores predisponentes ao desenvolvimento desse tipo de lesão, sendo que o material restaurador poderá contribuir mais decisivamente no processo quando estabelecer condições favoráveis ao desenvolvimento de microorganismos na interface dente/restauração.

BRANDAU; ZIEMIECKI; CHARBENEAU ${ }^{18}$ relataram não haver a presença de cárie secundária num estudo de 54 meses de acompanhamento com o cimento de ionômero de vidro convencional e que a sensibilidade diminuiu ou foi eliminada completamente após a restauração das lesões, permanecendo inalterada em todo o período de avaliação. No estudo conduzido por VANHERLE et al. ${ }^{122}$ houve a presença de cárie secundária em $6 \%$ dos casos, num período de avaliação de seis meses. Entretanto, os autores não relataram o número de pacientes da amostra, nem os critérios de inclusão no estudo.

No presente trabalho, analisando o critério sensibilidade, pôde-se notar que ambos os materiais foram capazes de eliminar completamente a sensibilidade após a restauração das lesões. Apenas um dente apresentou discreta sensibilidade, para os dois materiais, nos períodos de seis e doze meses. Estes dentes eram de um mesmo paciente e isto pode ser explicado por uma maior sensibilidade do referido paciente. Entretanto, no final da avaliação, nenhum dente apresentava sensibilidade.

A presença de sensibilidade em lesões cerviciais não cariosas ocorre devido àexposição dentinária ao meio bucal, tornando a estrutura tubular e sensível de dentina como uma via de fácil transporte de substâncias da cavidade bucal para a polpa ${ }^{84}$. A teoria hidrodinâmica da dentina sensível advoga 
que uma grande variedade de estímulos dolorosos induz a movimentação do fluido ao longo da dentina, e que essa movimentação excita os nervos próximos àpolpa. Essa teoria defende que o método mais efetivo de tratamento da sensibilidade dentinária é o bloqueio mecânico dos túbulos dentinários, o qual interfere na movimentação do fluido ao longo da dentina e diminui a excitabilidade dos nervos reduzindo, dessa forma, a sensibilidade dentinária ${ }^{85}$. Esse conceito é compartilhado por WICHGERS; EMERT ${ }^{125}$ ao relatarem que a restauração das lesões cervicais constitui um tratamento efetivo para a redução ou total eliminação da sensibilidade presente nessas lesões, pois promovem a obliteração dos túbulos, reduzindo a permeabilidade dentinária e a conseqüente movimentação dos fluidos em seu interior.

Como pôde ser notado através da revisão dos trabalhos de avaliação clínica, a diminuição da sensibilidade, com o passar do tempo, foi uma característica presente em todos os estudos revisados. A maioria dos autores explica que essa redução pode ser devida àobtenção de uma barreira mecânica associada àdiminuição da área de dentina exposta após a realização do tratamento restaurador.

Face àcondução bastante criteriosa da presente pesquisa, em todas suas etapas de execução, acredita-se que o objetivo principal da realização de um estudo desta natureza seja a contribuição dada àcomunidade científica no sentido de tentar esclarecer uma das inúmeras dúvidas concernentes aos diversos aspectos que envolvem a etiologia, o diagnóstico e o tratamento das lesões cervicais não cariosas. Pode-se constatar que as diferenças obtidas entre 0 comportamento dos materiais restauradores devam-se exclusivamente ao real desempenho clínico estabelecido pelas condições de similaridade para os materiais estudados. Dessa forma, a hipótese de igualdade estabelecida na proposição do estudo deve ser parcialmente aceita, uma vez que houve diferença estatisticamente significante entre os materiais no critério retenção aos dois anos de acompanhamento. Entretanto, mesmo com uma superioridade de resultados numéricos apresentados pelo cimento de ionômero de vidro modificado por resina 
composta, infere-se que um período de acompanhamento mais longo seja necessário para verificar o efetivo comportamento desses materiais. 


\section{CONCLUSÕES}

Com base nos resultados da análise estatística aplicada, pode-se concluir que:

1) Os materiais restauradores adesivos, resina composta e cimento de ionômero de vidro modificado por resina, apresentaram comportamento clínico semelhante com relação à integridade marginal, descoloração marginal, manutenção da forma anatômica (desgaste), incidência de cárie e sensibilidade pósoperatória; sendo que no critério retenção houve superioridade do cimento ionomérico;

2) Ao término do estudo, não foi observada presença de cárie ou sensibilidade pós-operatória;

3) O cimento de ionômero de vidro modificado por resina apresentou melhor desempenho do que a resina composta, não apresentando restaurações clinicamente inaceitáveis em nenhum aspecto avaliado; 


\section{REFERÊNCIAS BIBLIOGRÁFICAS`}

1. ABDALLA, A.I.; ALHADAINY, H.A. Clinical evaluation of hybrid ionomer restoratives in Class $V$ abrasion lesions: Two-year results. Quintessence Int., v.28, n.4, p.255-58, Apr. 1997.

2. ABDUSSALAM, M. et al. Declarações e diretrizes internacionais. Bioética, v.3, n.2, p.98-136, 1995

3. ALMEIDA, J.C.F. Avaliação microestrutural dos tecidos dentários mineralizdos na região cervical de pré-molares humanos com vistas à etiopatogenia das lesões cervicais não cariosas. Bauru, 2001. 168p. Dissertação (Mestrado) - Faculdade de Odontologia de Bauru, Universidade de São Paulo.

4. AMERICAN DENTAL ASSOCIATION. Council on Dental Materials and Devices. Recommended standard practices for clinical evaluation of dental materials and devices. J. Amer. dent. Ass., v.84, n.2, p.388-90, Feb. 1972.

5. AMERICAN DENTAL ASSOCIATION. Council on Scientific Affairs. Acceptance program guidelines. Restorative Materials, p.1-9, Mar. 1996.

6. ANUSAVICE, K.J. Quality evaluation of dental restorations: Criteria for placement and replacement. Chicago, Quintessence, 1989.

7. BADER, J.D. Case-control study of non-carious cervical lesions. Comm. dent. oral Epidemiol., v.24, n.4, p.286-91, Aug. 1996.

\footnotetext{
- Normas recomendadas para uso no âmbito da Universidade de São Paulo, com base no documento "Referências Bibliográficas: exemplos", emanado do Conselho Supervisor do Sistema Integrado de Bibliotecas da USP, em reunião de 20 de setembro de 1990.
} 
8. BANKOWSKI, Z. Diretrizes éticas internacionais para pesquisa biomédicas envolvendo seres humanos. Bioética, v.3, n.2, p.95-97, 1995.

9. BAYNE, S.C. et al. Contributing co-variables in clinical trials. Amer. J. Dent., v.4, n.5, p.247-50, Oct. 1991.

10. BELTRÃO, H.C.P. Avaliação clínica de materiais restauradores: método direto. Bauru, Faculdade de Odontologia de Bauru, 1993. /Monografia/

11. BEVENIUS,J.; L'ESTRANGE, P.; ANGMAR-MANSSON, B. Erosion: guidlines for the general practioner. Aust. dent.J., v.33, n.5, p.407-11, May 1988.

12. BOGHOSIAN, A. Clinical evaluation of a filled adhesive system in Class $V$ restorations. Compendium, v.17, n.8,p.750-57, Aug. 1996.

13. BRACKETT, W.W.; ROBINSON, P.B. Composite resin and glass ionomer cement: current status for use in cervical restorations. Quintessence Int., v. 21, n.6, p.445-7, June 1990.

14. BRACKETT, W.W. et al. Two-year clinical performance of a resin-modified glassionomer restorative material. Oper. Dent., v.24, n.1, p.9-13, Jan./Feb. 1999.

15. BRACKETT, W.W. et al. 1-year clinical evaluation of Compoglass and Fuji II LC in cervicalerosion/abfraction lesions. Amer. J. Dent., v.12, n.3, p.119-22, June 1999.

16. BRACKETT, W.W. et al. Two-year clinical performance of a polyacid-modified resin composite and a resin-modified glass-ionomer restorative material. Oper. Dent., v.26, n.1, p.12-6, Jan./Feb. 2001.

17. BRADY, J.M.; WOOD, R.D. Scanning microscopy of cervical erosion. J. Amer. dent. Ass., v.94, n.4, p.726-9, Apr. 1977. 
18. BRANDAU, H.E.; ZIEMIECKI, T.L.; CHARBENEAU, G.T. Restoration of cervical contours on nonprepared teeth using glass ionomer cement: $4^{1 / 2 y e a r}$ report. J. Amer. dent. Ass., v. 104, n. 5, p.782-83, May 1984.

19. BROWNING, W.D.; BRACKETT, W.W.; GILPATRICK, R.O. Retention of microfilled and a hybrid resin-based composite in non-carious Class $\mathrm{V}$ lesions: a double-blind, randomized clinical trial. Oper. Dent., v,24, n.1,p.2630, Jan./Feb. 1999.

20. BROWNING, W.D.; BRACKETT, W.W.; GILPATRICK, R.O. Two-year clinical comparison of microfilled and a hybrid resin-based composite in non-carious Class V lesions. Oper. Dent., v,25, n.1,p.46-50, Jan./Feb. 2000.

21. BRYANT, R.W.; RESS, F.T.; ROSS, I.D. Clinical evaluation of restorative resin with organic filler. Preliminary report and discussion. Aust. Dent. J., v.24, n.6, p.402-7, Dec. 1979.

22. BURROW, M.F.; TYAS, M.J. Clinical evaluation of a resin-modified glass-ionomer adhesive system. Oper. Dent., v.23, n.6, p.290-93. Nov./Dec. 1998.

23. BURROW, M.F.; TYAS, M.J. 1-year clinical evaluation of one-step in non-carious cervical lesions. Amer. J. Dent., v.12, n.6, p.283-85, Dec. 1999.

24. CARVALHO, R.M. Adesivos dentinários. Fundamentos para aplicação clínica. Rev. Dent. rest., v.1, n.2, p.62-96, 1998.

25. CARVALHO, R.M. et al. Determinação da resistência adesiva àdentina através de um dispositivo de microtração. Rev. FOB, v.2, n.3, p.77-82, jul./set. 1994. 
26. CHADWICK, R.G. et al. Comparison of a novel photogrammetric techique and modified USPHS criteria to monitor the wear of restorations. J. Dent., v.19, n.1, p.39-45, Feb. 1991.

27. CVAR, J.F. ; RYGE, G. Clinical evaluation of dental restorative materials. São Francisco, 1973. /Monograph/

28. di LENARDA, R.; CADENARO, M.; DORIGO, E.S. Cervical compomer restorations: the role of cavity etching in a 48-month clinical evaluation. Oper. Dent., v.25, n.5, p.382-7, Sept./Oct. 2000.

29. DUKE, E.S.; LINDEMOUTH, J. Variability of clinical dentin substrates. Amer. J. Dent., v.4, n.5, p.241-6, Oct. 1991.

30. DUKE, E.S. et al. Clinical and interfacial laboratory evaluation of a bonding agent in cervical abrasions. Amer. J. Dent., v.7, n.6, p. 307-11, Dec. 1994.

31. ELDERTON, R.J. The causes of failures of restorations: a literature review. J. Dent., v.4, n.6, p.257-62, Dec. 1976.

32. ELDERTON, R.J. The prevalence of failures of restorations: a literature review. J. Dent., v.4, n.6, p.207-10, Dec. 1976.

33. ELDERTON, R.J. Assessment of the quality of restorations - a literature review. J. oral Rehab., v.4, n.4, p.217-26, Oct. 1977.

34. ERICKSEN, H.M. Indirect clinical methods for evaluation of resin filling materials. Int. dent. J., v.30, n.4, p.359-63, Dec. 1980.

35. FEDERATION DENTAIRE INTERNATIONAL. Commission on Dental Products. Recommendations for clinical research protocols for dental materials. Int. dent. J., v.32, n.4, p.403-5, Dec. 1982. 
36. FEILZER, A.J.; DE GEE, A.J.; DAVIDSON, C.L. Increased wall-to-wall curing contraction in thin bonded resin layers. J. dent. Res., v.68, n.1, p.48-50, Jan. 1989.

37. FERRARI, M. et al. Clinical and laboratory evaluation of adhesive restorative systems. Amer. J. Dent., v.7, n.4, p.217-9, Aug. 1994.

38. FOLWACZNY, M. et al. Determination of changes on tooth-colored cervical restorations in vivo using a three-dimensional laser scanning device. Europ. J. oral Sci., v.108, n.3, p.233-8, June 2000.

39. FOLWACZNY, M. et al. Tooth-colored filling materials for the restoration of cervical lesions: a 24-month follow-up study. Oper. Dent., v.25, n.4, p.251-8, July/Aug. 2000.

40. FOLWACZNY, M. et al. Class V lesions restored wiyh four different tooth-colored materials - 3-year results. Clin. oral Invest., v.5, n.1, p.31-9, Jan. 2001.

41. FOLWACZNY, M. et al. Clinical performance of a resin-modified glass-ionomer and a compomer in restoring non-carious cervical lesions. 5-year results. Amer. J. Dent., v.14, n.3, p.153-6, June 2001.

42. FREITAS, C.B.; LOBO, M. O sistema CEP/CONEP. Cadernos de ética em pesquisa, v.3, n.7, p.4-13, mar. 2001.

43. FRITZ, U.B.; FINGER, W.J.; UNO, S. Resin-modified glass ionômer cements: bonding to enamel and dentin. Dent. Mater., v.12, n.3, p.161-6, May 1996.

44. GALLIEN, S.G.; KAPLAN, I.; OWENS, B.M. A review of noncarious dental cervical lesions. Comp. Continuing Educ. Dent., v.15, n.11, p.1366-71, Nov. 1994. 
45. GARCEZ, R.M.V.B. Avaliação da liberação de resinas compostas em água em ciclagem de pH. Bauru, 2001. 124p. Dissertação (Mestrado) Faculdade de Odontologia de Bauru, Universidade de São Paulo.

46. GLADYS, S. et al. Marginal adaptation and retention of a glass-ionomer, resinmodified glass-ionomers and a polyacid-modified resin composite in cervical Class-V lesions. Dent. Mater., v.14, n.4, p.294-306, July 1998.

47. GORDON, D.F. Quality standards: their establishment for Dentistry. J. Calif. dent. Ass., v.2, n.4, p.43-5, Apr. 1974.

48. GRIPPO, J.O. Abfractions: a new classification of hard tissue lesions of teeth. J. Esthet. Dent., v.3, n.1, p.14-9, Jan./Feb. 1991.

49. GRIPPO, J.O. Non-carious cervical lesions: the decision to ignore or restore. J. Esthet. Dent., v.4, p.55-64, 1992. Supplement.

50. HANAOKA, K. et al. A biomechanical approach to the etiology and treatment of noncarious dental cervical lesions. Bull. Tokyo dent. Coll., v.26, n.2, p.10313, Sept. 1998.

51. HANSEN, E.K. Five-year study of cervical erosions restored with resin and dentin-bonding agent. Scand. J. Dent. Res., v.100, n.4 , p. 244-7, Aug. 1992.

52. HeIDEMANN, D. Preparación de cavidades. In: KETTERL, W. et al. Odontologia conservadora - cariologia. Tratamiento mediante obturacion. Barcelona, Masson-Salvat, 1994. Cap. 5, p.67-134. 
53. HEWLETT, E. R. ; JO, Y. H.; HOBO, S. Restorative esthetic procedures: direct composite and glass-ionomer. In: CRISPIN, B. J., ed. Contemporary esthetic dentistry: practice fundamentals. Tokyo, Quintessence, 1994. Cap. 4, p. 105-36.

54. HEYMANN, H.O. et al. Twelve-month clinical study of dentinal adhesives in Class V cervical lesions. J. Amer. dent. Ass., v. 116, n.2, p.179-83, Feb. 1988.

55. HEYMANN, H.O. et al. Examining tooth flexure effects on cervical restorations: a two-year clinical study. J. Amer. dent. Ass., v.122, n.5, p.41-7, May 1991.

56. HEYMANN, H.O.; BAYNE, S.C. Current concepts in dentin bond: Focusing on dentinal adhesion factors. J. Amer. dent. Ass., v.124, n.5, p.27-36, May 1993.

57. HOOD, J.A.A. Biomechanics of the intact, prepared and restored tooth: some clinical implications. Int. dent. J., v.41, n.1, p.25-32, Feb. 1991.

58. HÖRSTED-BINDSLEV, P.; KNUDSEN, J.; BAELUM, V. 3-year clinical evaluation of modified Gluma adhesive systems in cervical abrasion/erosion lesions. Amer. J. Dent., v.9, n.1, p.22-6, Feb. 1996.

59. HOSSNE, W.S. Ética? Isso é coisa de filósofo. Cadernos de ética em pesquisa, v.3, n.7, p.3, mar. 2001.

60. HTTP:// WWW.FOB.USP.BR/ADM/COMISSOES/CEP/DOCS.HTM

61. IANZANO, J.A.; GWINNETT, A.J. Clinical evaluation of Class $V$ restorations using a total etch technique: 1-year results.Amer. J. Dent., v.6, n.4, p.207-10, Aug. 1993. 
62. JACOBSEN, P.H. Design and analysis of clinical trials. J. Dent., v.16, n.5, p.2158, Oct.. 1988.

63. JOKSTAD, A. et. al. Quality of dental restorations: FDI commission project 2-95. Int. dent. J., v.51, n.3, p.117-58, June 2001.

64. JONAS,P.; LASFARGUES, J.J.; DEGRANGE, M. In: DAVIDSON, C.L.; MJÖR, I.A.(Ed.) Clinical application of glass-ionomer cement: Class III and Class V restorations. Chigaco,Quintessence, 1999, Cap.12, p.227-52.

65. LAMBERT, R.L.; LINDENMUTH, J.S. Abfraction - a new name for an old entity. J. Calif. dent. Ass., v.72, n.3, p.31-3, Jan. 1994.

66. LEE, W.C.; EAKLE, W.S. Possible role of tensile stress in the etiology of cervical erosive lesions of teeth. J.prosth. Dent., v.52, n.3, p.374-9, Sept. 1984.

67. LEE, W.C.; EAKLE, S.W. Stress-induced cervical lesions: reviews of advances in past 10 years. J.prosth. Dent., v.75, n.5, p.487-94, May 1996.

68. LEINFELDER, K.F.; LEMONS, J.E. Avaliação clínica. In: Clínica restauradora: materiais e técnicas. São Paulo, Santos, 1989. Cap.8, p.20137.

69. LIEBENBERG, W.H. Rubber dam isolation of cervical lesions. part 1: alternative techniques which avoid injury to the periodontium. FDI World, v.3, n.5, p.17-8 Sept./Oct. 1994

70. LIN, A.; McINTYRE, N.S.; DAVIDSON, R.D. Studies on the adhesion of glassionomer cements to dentin. J. dent. Res., v.71, n.11, p.1836-41, Nov. 1992.

71. LYONS, K. Aetilology of abfraction lesions. New Zealand dent. J., v.97, n.429, p.93-8, Sept. 2001. 
72. MANDRAS, R.S. et al. Three-year clinical evaluation of the clearfil liner bond system. Oper. Dent., v. 22, n.6 , p.266-70 Nov./Dec. 1997.

73. MANEENUT, C.; TYAS, M.J. Clinical evaluation of resin-modified glass-ionomer restorative cements in cervical 'abrasion' lesions: one-year results. Quintessence Int., v.26, n.10, p.739-42, Oct. 1995.

74. MATIS, B.A.; COCHRAN, M.; CARLSON, T. Longevity of glass-ionomer restirative materials: results of a 10-year evaluation. Quintessence Int., v.27, n.6, p.373-82, June 1996.

75. MATIS, B.A. et al. Clinical evaluation and early finishing of glass ionomer restorative materials. Oper. Dent., v.13, n.2, p.74-80, Spring, 1988.

76. MAYHEW, R.B.; JESSEE, S.A.; MARTIN, R.E. Association of occlusal, periodontal, and dietary factors with the presence of non-carious cervical dental lesions. Amer. J. Dent., v.11, n.1, p.29-32, Feb. 1998.

77. McCOY, G. On the longevity of teeth. Oral implantology, v.11, n.2, p.248-67, Feb. 1983.

78. MILOSEVIC, A. Toothwear: a etiology and presentation. Restorat. Dent., v.25, n.1, p.6-11, Jan./Feb. 1996.

79. MJÖR, I.A. Dentin-predentin complex and its permeability: pathology and treatment overview. J. dent. Res., v.64, p.607-12, Apr. 1985. Special issue.

80. NEO, J.; CHEW, C.L. Direct tooth-collored materials for noncarious lesions: a 3year clinical report. Quintessence Int., v.27, n.3, p.183-8, Mar. 1996. 
81. NEO, J. et al. Clinical evaluation of tooth-collored materials in cervical lesions.

Amer. J. Dent., v. 9, n.1, p.15-8, Feb. 1996.

82. NEVES, A.D.; DISCACCIATI, J.A.C. Abfração:etiologia, diagnóstico e tratamento.

Rev. CROMG, v.5, n.2, p.100-105, mai./ago. 1999.

83. OSBORNE-SMITH, K.L.; BURKE, F.J.T.; WILSON, N.H.F. The aetiology of the non-carious cervical lesion. Int. dent. J., v.49, n.3, p.139-43, June 1999.

84. PASHLEY, D.H. Dentin permeability: theory and practice. In: SPANGBERG, L.S.W. ed. Experimental endodontics. Florida, CRC Press, 1990 p. 19-49.

85. PASHLEY, D.H. Dentin sensitivity: theory and treatment. Focus on adult oral Health, v.1, n.2, p.1-7, July, 1993.

86. PASHLEY, D.H.; CARVALHO, R.M. Dentine permeability and dentine adhesion. J. Dent., v.25, n.5, p.355-72, Sept. 1997.

87. POWELL, L.V.; JOHNSON, G.H.; GORDON, G.E. Factors associated with clinical sucess of cervical abrasion/erosion restorations. Oper Dent., v.20, n.1, p.7-13, Jan./Feb. 1995.

88. POWIS, D.R. et al. Improved adhesion of glass ionomer cement to dentin and enamel. J. Dent. Res., v.61, n.12, p.1416-422, Dec., 1982

89. PRATI, C. et al. Marginal morphology of Class V composite restorations. Amer. J. Dent., v. 10, n.5, p.231-36, Oct. 1997.

90. RADENTZ, W.H.; BARNES, G.P.; CUTRIGHT, D.E. A survey of factors possibly associated with cervical abrasion of tooth surfaces. J. Periodont., v.47, n.3, p.148-54, Mar. 1976. 
91. RAMOS, D.L.P. Ética na pesquisa odontológica com seres humanos. Rev. Fac. Odont. USP., v.10, n.1, p.1-2, jan./mar. 1996.

92. RYGE, G. Clinical evaluation of adhesive restorative materials. Presented at $\mathbf{2}^{\text {nd }}$ Workshoop on Adhesive Restorative Dental Materials. University of Virginia, 1965.

93. RYGE, G.; CVAR, J.F. Clinical evaluation of new and conventional anterior restorative materials. In: Symposium on Recent Advances in Dental Materials, Federation Dentaire International, Israel, 1966.

94. RYGE, G. Clinical criteria. Int. dent. J., v.30, n.4, p.347-58, Dec. 1980.

95. RYGE, G. ; SNYDER, M. Evaluating the clinical quality of restorations. J. Amer. dent. Assoc., v.87, n.2, p.369-77, Aug. 1973.

96. SAITO, S.; TOSAKI, S.; HIROTA, K. In: DAVIDSON, C.L.; MJÖR, I.A.(Ed.) Characteristics of glass-ionomer cements. Chigaco ,Quintessence, 1999, Cap.1, p.15-50.

97. SAKOOLNAMARKA, $R$. et al. Micromorphological investigation of noncarious cervical lesions treated with demineralizing agents. J. Adhes. Dent., v.2, n.4, p. 279-87, Winter, 2000.

98. SIDHU, S.K.; WATSON, T.F. Resin-modified glass ionomer materials: a status report for the Americam Journal of Dentistry. Amer. J. Dent., v.8, n.1, p.59-67, Feb. 1995.

99. SILVA E SOUZA JÚNIOR, M.H.; CARVALHO, R.M.; MONDELLI, R.F.L. Odontologia estética - fundamnetos e aplicações clínicas. São Paulo, Santos, 2000. 
100. SMALES, R.J. Evaluation of clinical mehods for assessing restorations. J. prosth. Dent., v.49, n.1, p.67-70, Jan. 1983.

101. STANFORD, J.W.; RYGE, G. Recommended outline for a research protocol. Int. dent. J., v.27, n.1, p.44-5, Mar 1977.

102. STANLEY, H.R. et al. The detection and prevalence of reactive and physiologic sclerotic dentin, reparative dentin and dead tracts beneath various types of dental lesions according to tooth surface and age. J. Oral Path., v.12, n.4, p.257-89, 1983.

103. SWIFT JUNIOR, E.J. Fluoride release from two composite resins. Quintessence Int., v.20, n.12, p.895-7, Dec. 1989.

104. SWIFT JUNIOR, E.J. et al. Eighteen-month clinical evaluation of a filled and unfilled dentin adhesive. J. Dent., v.29, n.1, p.1-6, Jan. 2001.

105. SWIFT JUNIOR, E.J. et al. Clinical evaluation of two one-bottle dentin adhesives at three years. J. Amer. dent. Ass., v.132, n.8, p.1117-123, Aug. 2001.

106. TAY, F.R. et al. Ultrastructural analysis of the bonding between adhesive systems and sclerotic servical dentin. In: ADVANCED ADHESIVE DENTISTRY; $3^{\text {rd }}$ INTERNATIONAL KURARAY SYMPOSIUM. Proceedings. Granada, Erredue, 1999. p.105-30

107. TELLES, D.; PEgORARO, L.F.; PEREIRA, J.C. Prevalence of noncarious cervical lesions and their relation to occlusal aspect: a clinical study. $\mathbf{J}$. Esthet. Dent., v.12, n.1, p. 10-15, 2000.

108. TYAS,M.J. Clinical evaluation of five adhesive systems. Amer. J. Dent., v.7, n.2, p.77-80, Apr.1994. 
109. TYAS, M.J. Three-year clinical evaluation of Tenure dentine bonding agent. Aust. Dent. J., v.39, n.3, p.188-9, June 1994.

110. TYAS, M.J. The Class V lesion - aetiology and restoration. Aust. dent. J., v.40, n.3, p.167-70, June 1995.

111. TYAS, M.J. Clinical evaluation of five adhesive systems: three-year results. Int. dent. J., v.46, n.1, p.10-4, Mar. 1996.

112. TYAS, M.J. Clinical evaluation of a polyacid-modified resin composite (compomer). Oper. Dent., v. 23, n.2, p.77-80, Mar./Apr. 1998.

113. TYAS, M.J.; BURROW, M.F. Clinical evaluation of EBS dentine bonding agent: one year results. Aust. dent. J., v.45, n.2, p.115-17, June 2000.

114. TYAS M.J.; BURROW M.F. Clinical evaluation of a resin-modified glass ionomer adhesive system-results at three years. Oper. Dent., v.26, n.1, p.17-20, Jan./Feb. 2001.

115. VAN DIJKEN, J.W.V. Clinical evaluation of four dentin bond agents in Class V abrasion lesions: A four-year follow-up. Dent. Mater., v.10, n.9, p.319-24, Sept. 1994.

116. VAN DIJKEN, J.W.V. Clinical evaluation of three adhesive systems in Class V non-carious lesions. Dent. Mater., v. 16,n.4, p. 285-91, Apr. 2000.

117. VAN MEERBEEK, B. et al. Two-year clinical evaluation of two dentine-adhesive systems in cervical lesions. J. Dent., v.21, n.4, p.195-202, Aug. 1993.

118. VAN MEERBEEK, B. et al. Evaluation of two dentin adhesives in cervical lesions. J. prosth. Dent., v.70, n.4, p.308-14, Oct. 1993. 
119. van MEERBEEK, B. et al. Clinical status of ten dentin adhesive systems. J. dent. Res., v.73, n.11, p.1690-702, Nov. 1994.

120. VAN MEERBEEK, B. et al. Three-year clinical effectiveness of four total-etch dentinal adhesive systems in cervical lesions. Quintessence Int., v.27, n.11, p.775-67, Nov. 1996.

121. van MEERBEEK, B. et al. The clinical performance of adhesives. J. Dent., v.26, n.1, p.1-20, Jan. 1998.

122. VANHERLE, G. et al. Clinical investigation of dental adhesive systems. Part I: an in vivo study. J. prosth. Dent., v.55, n.2, p.157-63, Feb. 1986.

123. VERBEECK, R.M.H. et al. Fluoride release process of (resin-modified) glassionomer cements versus (polyacid-modified) composite resin. Biomaterials, v. 19, n.6, p.509-20, June, 1998.

124. WATSON, T.F. In: DAVIDSON, C.L.; MJÖR, I.A.(Ed.) Bonding glass-ionomer cements to tooth structure. Chigaco ,Quintessence, 1999, Cap.6, p.12135 .

125. WICHGERS, T.G.; EMERT, R.L. Dentin hypersensitivity. Oral Health, v.87, n.3, p.51-9, Mar. 1997.

126. WILSON, A.D. Development in glass-ionomer cements. Int. J. Prosth., v.2, n.5, p. 438-46, Sept./Oct., 1989.

127. XHONGA, F.A.; WOLCOTT, R.B.; SOGNNAES, R.F. Dental erosion - clinical measurements of dental erosion progress. J. Amer. dent. Ass., v.84, n.3, p.577-82, Mar. 1972. 
128. YAP, A.U.J.; NEO, J.L.C. Non-carious cervical tooth loss: part 1. Dent. Update, v.22, n.8, p.315-8, Oct. 1995.

129. YAP, A.U.J.; NEO, J.L.C. Non-carious cervical tooth loss. Part 2: management. Dent. Update, v.22, n.9, p.364-8, Nov. 1995.

130. YAP, A.U.J.; KHOR, E.; FOO, S.H. Fluoride release and bacterial properties of new-generation tooth-collored restoratives. Oper. Dent., v.24, n.5, p.297305, Sept./Oct. 1999.

131. YOSHIYAMA, M. et al. Regional strengths of bonding agents to cervical sclerotic root dentin. J. dent. Res., v.75, n.6 p.1404-13, June 1996.

132. ZAVRAS, A.I.; GYPSON, B. High-quality research and patient care: an overview of clinical trials. J. Amer. dent. Ass., v.131, n.8, p.1147-55, Aug. 2000.

133. ZIEMIECKI, T.L.; DENNISON, J.B.; CHARBENEAU, G.T. Clinical evaluation of cervical composite resin restorations placed without retention. Oper, Dent., v.12, n.1, p.27-33, Winter, 1987. 


\section{ABSTRACT \\ Clinical Evaluation of Restorations in Non-Carious Cervical Lesions}

The purpose of this study was to assess the clinical performance of a monocomponent adhesive system (Excite/Tetric-Ceram Vivadent) and a resin-modified glass ionomer cement (Vitremer - $3 \mathrm{M}$ ) to restore non-carious cervical lesions using a modified USPHS system. A total of 70 restorations (thirty-five per material) were performed by one operator in 30 patients 23-68 aged. Prior to restorations, teeth were pumiced with a prophy cup and restored following manufacturer's instructions. All restorations were directly evaluated by two examiners at baseline, 6 months, 1 year and 2 years using the following: retention, marginal integrity, marginal discoloration, wear, recurrent caries postoperative and sensitivity. After two years. The ratings (Alpha and Bravo) of clinical satisfactory restorations were as follows (Tetric-Ceram/Vitremer): retention (79\%/100\%), marginal integrity (100\%/100\%), marginal discoloration (100\%/100\%), wear (96\%/100\%), recurrent caries (100\%/100\%) and postoperative sensitivity (100\%/100\%). Statistical analysis was completed with Fisher's exact or Pearson Chi-square tests at a significance level of $5 \%(P<0.05)$. Intra-groups comparison was completed with McNemar's test at a significance level of $5 \%(P<0.05)$. Results showed that all restorations of resinmodified glass ionomer cement were clinically satisfactory and there was significant difference between materials in retention criterion at 2 years of evaluation. 